\title{
15. SHALLOW-WATER CARBONATE SEDIMENTS FROM THE EMPEROR SEAMOUNTS: THEIR DIAGENESIS AND PALEOGEOGRAPHIC SIGNIFICANCE
}

\author{
Judith McKenzie, Geologisches Institut, Eidg. Tech. Hochschule, Zürich, Switzerland \\ Daniel Bernoulli, Geologisch-Paläontologisches Institut der Universität, Basel, Switzerland \\ and \\ Seymour O. Schlanger, Hawaii Institute of Geophysics, University of Hawaii at Manoa, Honolulu, Hawaii
}

\begin{abstract}
Deep sea drilling on four seamounts in the Emperor Seamount chain revealed that Paleogene shallow-water carbonate sediments of the "bryozoan-algal" facies crown the basalt edifices. According to the biofacies model of Schlanger and Konishi $(1966,1975)$, this bryozoan-algal assemblage suggests that the seamounts formed in cooler, more northerly waters than those presently occupied by the island of Hawaii; i.e., the paleolatitudes of formation were greater than $20^{\circ} \mathrm{N}$. Moving southward toward the youngest member of the seamount chain, a facies gradient indicative of warmer waters was observed. This gradient is interpreted as a reflection of a northward shift in isotherms during the time span in which the seamounts were progressively formed (Savin et al., 1975). On all seamounts, sedimentation at the drilling sites occurred in a high-energy environment with water depths of approximately 20 meters. Early-stage carbonate diagenesis began in the phreatic zone in the presence of meteoric water, but proceeded after subsidence of the seamounts into intermediate sea waters, where the bulk, stable isotopic composition was determined. The subsidence into intermediate waters was rapid, and permitted establishment of an isotopic equilibrium which, like the facies gradient, reflects the northward shift in isotherms during the Paleogene. Calcite and zeolite cements comprise the later-stage diagenesis, and originated from solutions arising from the hydrolysis of the underlying basalt.

In conclusion, the results of this study of the shallow-water carbonate sediments are not inconsistent with a paleolatitude of formation for Suiko Seamount (Site 433) of $26.9 \pm 3.5^{\circ} \mathrm{N}$, as determined by paleomagnetic measurements (Kono, this volume).
\end{abstract}

\section{INTRODUCTION}

Shallow-water carbonate sediments were recovered at DSDP Sites 308, 430, 432, and 433 (Figure 1) from the tops of seamounts in the Emperor Seamount chain. Stratigraphically, they lie above subaerially erupted basalts and below younger pelagic sediments. The existence of such shallow-water sediments on deeply submerged seamounts is not completely unexpected; their presence is in accord with Darwin's (1842) classic theory of coral reef formation, which relates the sequential development of fringing reefs, barrier reefs, and atolls to the subsidence of mid-ocean volcanic islands.

In the Pacific Ocean, the presence of shallow-water sediments on deeply submerged seamounts has been previously observed. First reports, such as the study Sunken Islands of the Mid-Pacific Mountains by Hamilton (1956), were based on dredge hauls. Later reports are based on cores recovered by the Glomar Challenger. On Horizon Guyot, DSDP Site 171, shallow-water bioclastic limestones were drilled (Winterer, Ewing, et al., 1973), and on Ita Matai Seamount, DSDP Site 202, oölites were found (Hesse, 1973). In the Emperor Seamount chain, on Kōkō Seamount, DSDP Site 308, biogenic volcanic sandstones containing coralline algae, bryozoans, and occasional corals were encountered (Matter and Gardner, 1975). In the case of the Emporer Seamounts, the presence of coral reefs, inferred from the composition of dredge hauls and the interpretation of seismic reflection profiles, has been postulated as an indicator of northward movement of the seamounts as predicted by the hot-spot hypothesis (Greene et al., 1978).

The recovery of shallow-water carbonates during Leg 55 was not therefore unexpected, but, at least for Suiko Seamount (Site 433), the bioclastic sediments failed to contain the anticipated coral components. In fact, according to the biofacies model of Schlanger and Konishi $(1966,1975)$, the bryozoan-algal assemblage in these sediments placed their formation beyond the northern limits of major coral reef production. On the other hand, the fossil assemblage is consistent with a paleo- 


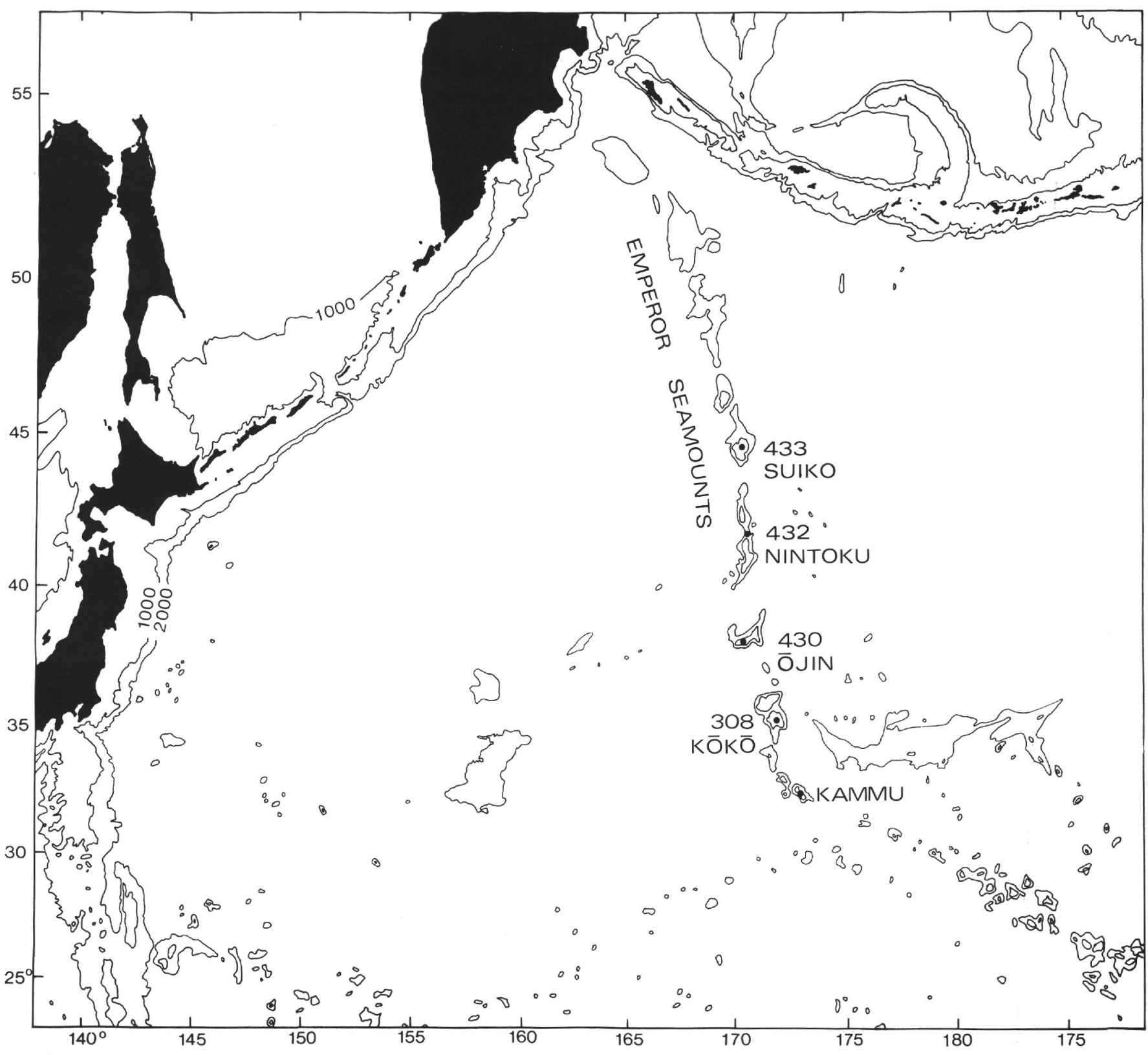

Figure 1. Index map of the northwest Pacific Ocean, showing locations of the deep sea drilling sites on the Emperor Seamount chain. Bathymetry from Chase et al. (1971).

latitude of formation for the seamount of $26.9 \pm 3.5^{\circ} \mathrm{N}$, as determined by paleomagnetic measurements (Kono, this volume). Further analysis of these carbonate sediments was required to obtain additional information concerning their environments of formation and alteration. For this reason, we studied the shallow-water carbonates from the Emperor Seamount chain using petrographic, stable isotopic, X-ray diffraction, and SEM techniques. It was hoped that a compilation of data on the composition and diagenesis of these sediments would provide information applicable to the broader theme of DSDP Leg 55, the testing of the hot-spot hypothesis for the origin of the Hawaiian and Emperor chains.

\section{CARBONATE FACIES}

\section{Suiko Seamount, Site 433}

At Site 433, the basaltic edifice of Suiko Seamount is overlain by 111 meters of middle to upper Paleocene, white and gray, shallow-water carbonate sands (Cores 433A-7 through $433 \mathrm{~A}-19,433 \mathrm{~B}-1$ to $433 \mathrm{~B}-4$, and $433 \mathrm{C}$ 1) (Figure 2). These shallow-water carbonates are disconformably overlain by lower Miocene to upper Pliocene marly diatom-nannofossil oozes. Near the contact with the underlying basalt, the carbonate sands are moderately to strongly cemented (Figure 3, Plates 1 and 4). Stratigraphically higher up, the sediments consist of white and gray uncemented skeletal sands with large 


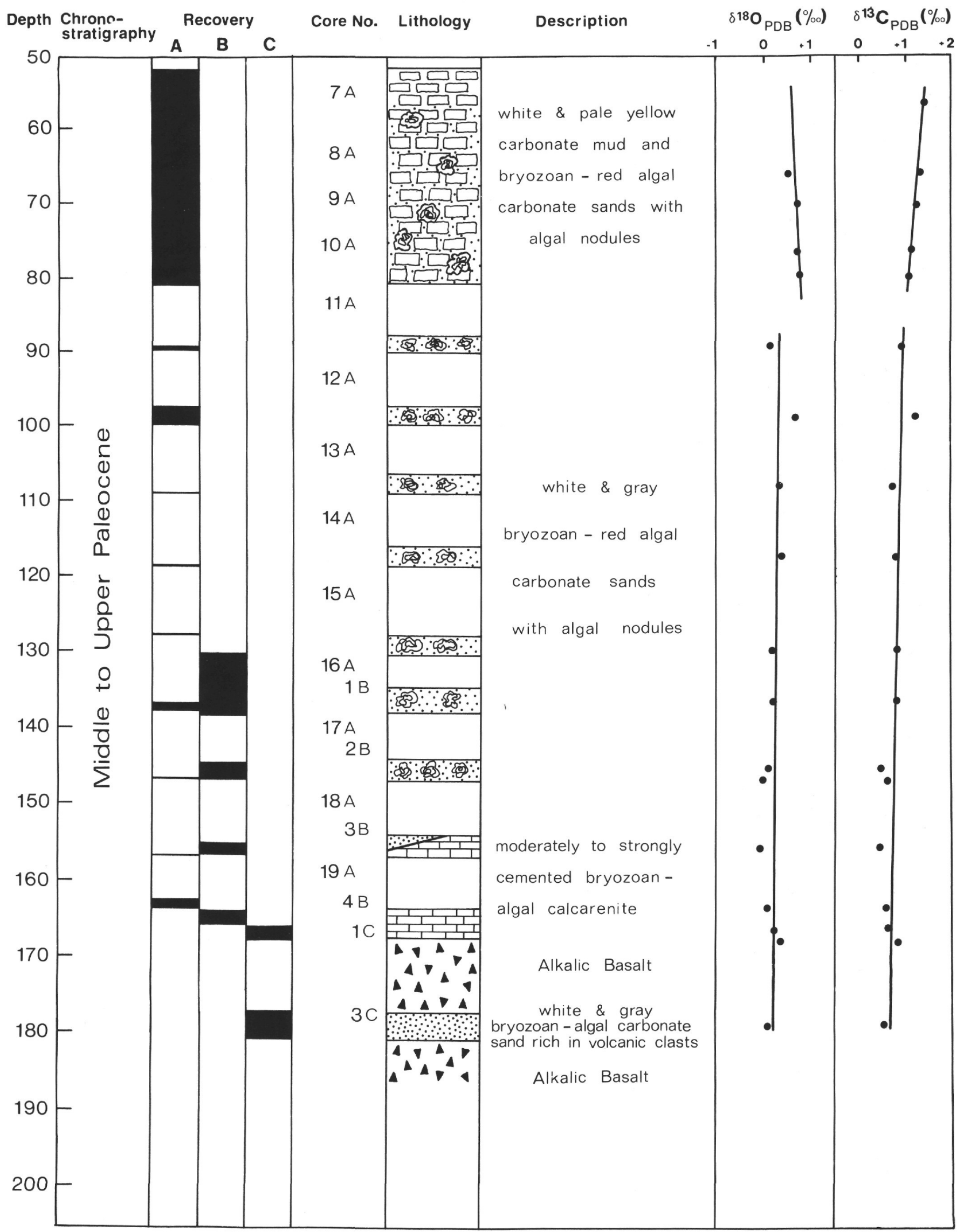

Figure 2. A lithostratigraphic column for the shallow-water carbonate sediments from Suiko Seamount, DSDP Site 433. The stable-isotopic values of the carbonates are plotted with respect to their stratigraphic positions. 


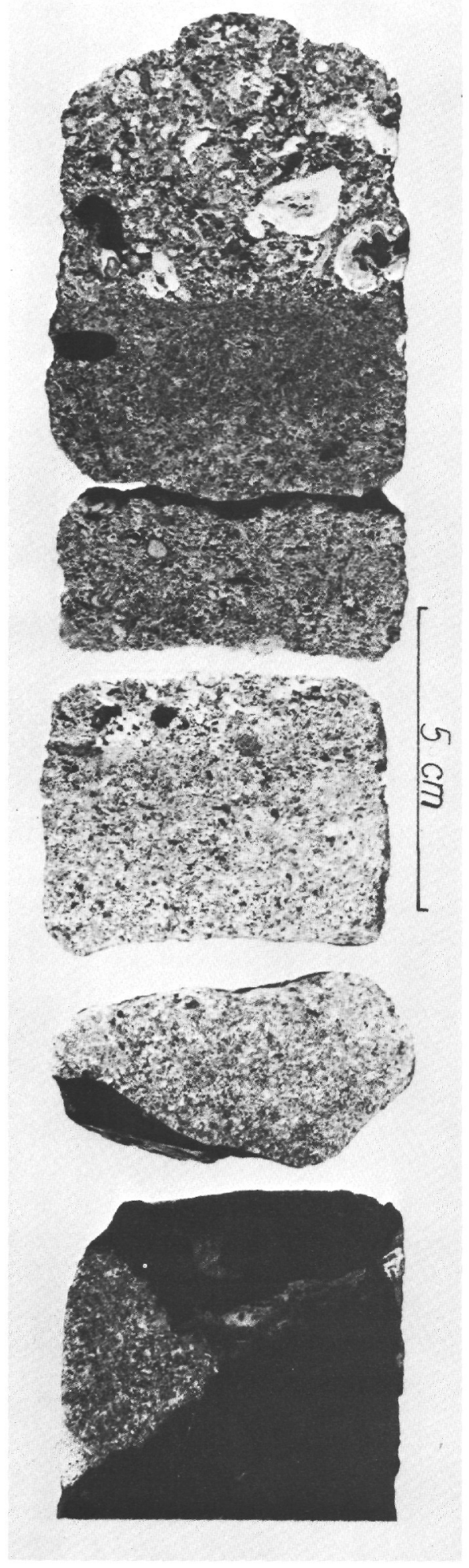

Figure 3. Basalt from Suiko Seamount overlain by skeletal calcarenites and calcirudites, showing an upward decrease in cementation (Sample 433B$4-1,15-40 \mathrm{~cm}$ ). algal nodules, called rhodolites (Bosellini and Ginsburg, 1971) (Figure 4). There is an upward increase in the admixture of pelagic carbonate mud, and about 80 meters above the basalt/sediment contact, the color changes from white and gray to white and pale yellow. At the contact with the overlying pelagic sequence, a thin layer of volanic mud occurs; it is rich in altered volcanic fragments, palagonite, volcanic glass, phosphatized granules, quartz, feldspar, phillipsite, and siliceous microfossils (Samples 433A-6-7,CC)(Figure 5). The abundant sponge spicules and radiolarians in this level probably constitute a winnowed lag desposit, which was accumulated over periods of extremely slow deposition.

The uncemented carbonate sands consist essentially of skeletal debris, which comprises mainly coralline algae and bryozoans with an admixture of ostracodes, lamellibranch and echinoderm fragments, coccoliths, and some rounded volcanic debris. Perforate larger foraminifers occur only very rarely, and relics of green algae or corals have not been observed in these uncemented carbonate sands. Smaller grains, mainly micritized fossil fragments, are loosely cemented by calcite micrite into grapestone lumps and aggregates (Figure 6). Coralline algae and bryozoans form granule-to pebblesized composite spheroidal nodules, rhodolites, which have laminar and columnar growth forms (Figure 4).

There is a general down-section increase in cementation from loosely cemented calcarenites (Cores433A$16,433 \mathrm{~B}-1)$ to completely cemented limestones at the basalt/sediment contact (Cores 433B-4, 433C-1) (Figure $3)$. These cemented calcarenites are washed biosparites to biosparrudites. Their composition is essentially the same as that of the overlying sands, with the visible exception of formerly aragonitic grains. Again, skeletal debris contains coralline algae and bryozoans as the main constituents (Plate 1), and echinoderms, bivalves, gastropods, ostracodes, fish debris, and occasional codiacean algae (Halimeda) vary in abundance. In the finer grained, moderately sorted calcarenites, much of the corralline algal debris is well rounded; in the coarse unsorted biosparrudites, nodules composed of alternating laminae of coralline algae, bryozoans, and some worm tubes are present. Corals, larger orbitoid foraminifers, or ooids are absent. Additionally, rounded clasts of basalt, palagonite, feldspars, and fresh pyroxenes with "hacksaw" terminations, indicative of intrastratal dissolution, occur. All these particles are cemented by a first generation of fibrous palisade calcite and a second generation of blocky calcite and phillipsite.

In Core 433B-4-1, $37 \mathrm{~cm}$, there is a sharp boundary contact between the bioclastic calcarenites and the superficially weathered basalt (Figure 3). This contact truncates an earlier infill of carbonate sediments, which consists of a fully cemented clotty limestone with a neomorphic fabric of sparry calcite. In Core 433C-3, a layer of uncemented, well-sorted sand containing about 70 per cent shallow-water carbonates, mainly bryozoans and coralline algae, and 30 per cent volcanic debris, was found intercalated between basalt Flows 1 and 2 (Site 


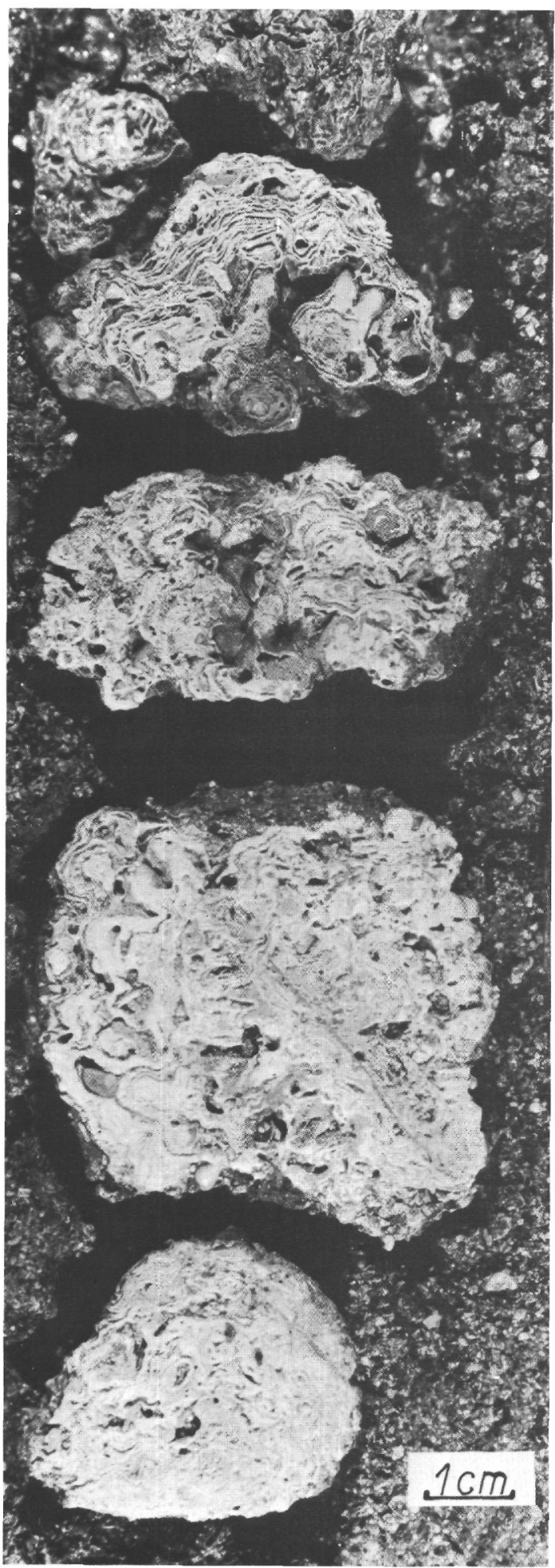

Figure 4. Middle to upper Paleocene algalbryozoan rhodolites with laminar and columnar growth forms. From Suiko Seamount (Sample 433B-1-7, 27-45 cm).

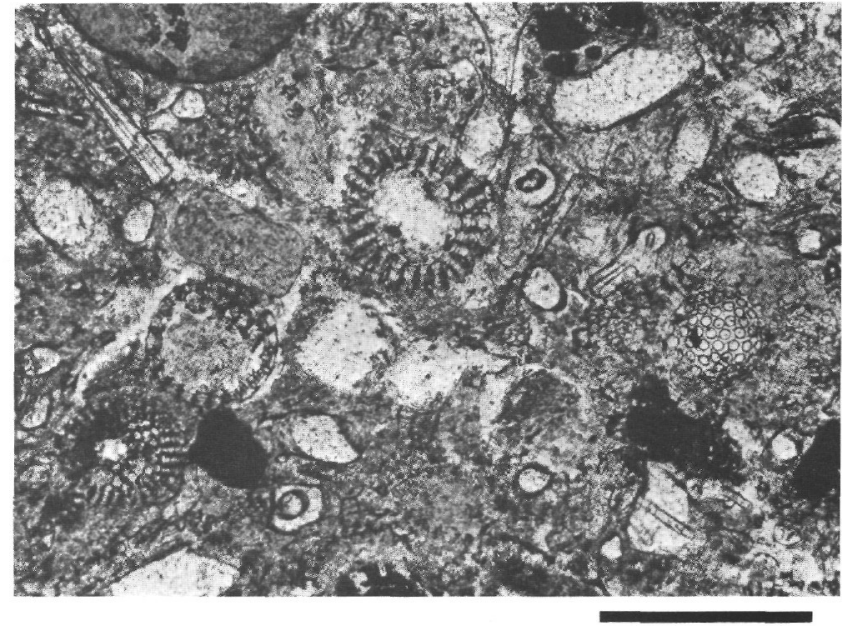

Figure 5. Volcanic mud rich in basaltic fragments, palagonite, volcanic glass, quartz, feldspar, radioloarians, and sponge spicules. This lithology occurs at the disconformity between the middle to upper Paleocene shallow-water carbonates and the overlying lower Miocene diatom-nannofossil oozes, and probably is a winnowed lag deposit accumulating over a period of slow deposition during sinking of the seamount. Site 433A, Samples 6,CC and 7,CC. Thin section: plane light. Scale bar: $0.5 \mathrm{~mm}$.

433 Report, this volume). Alternatively, this uncemented sand could simply be a drilling artifact.

\section{Nintoku Seamount, Site 432}

On Nintoku Seamount, about 3.5 meters of upper Paleocene-lower Eocene volcanic arenites and rudites, overlying the basalt, were recovered. They contain commonly rounded, more or less altered, sand- or granulesized basaltic fragments and whole and abraded biogenic components in a matrix of volcanic-bioclastic sandstone (Figure 7). These sediments are cemented by fibrous and blocky calcite (Samples 432A-1-1, $46 \mathrm{~cm}$ and $432 \mathrm{~A}-2-1,5 \mathrm{~cm}$ ) or by a brown, highly birefringent smectite rim which preceded cementation by sparry calcite (Plate 6, figure 6). An epiclastic origin for the basaltic fragments is suggested by their varied composition, texture, and degree of alteration. The volcanic debris also contains montmorillonite aggregates, fragments of palagonite, and iron-rich crusts. Carbonate particles include algal-bryozoan rhodolites with laminar and columnar growth forms, coralline algae, bryozoans, some echinoderms, bivalves, calcite-filled gastropod molds, brachiopods, ostracodes, and foraminifers, mainly miliolids. Some of the carbonate particles show possible algal borings which are filled by limonitic material. Corals, green algae, and ooids are absent.

\section{Ōjin Seamount, Site 430}

On Ōjin Seamount, about 47 meters of upper Paleocene to middle Eocene calcareous ooze and sand have been found above the volcanic rocks of the seamounts. Cemented calcarenites occur close to the basalt 

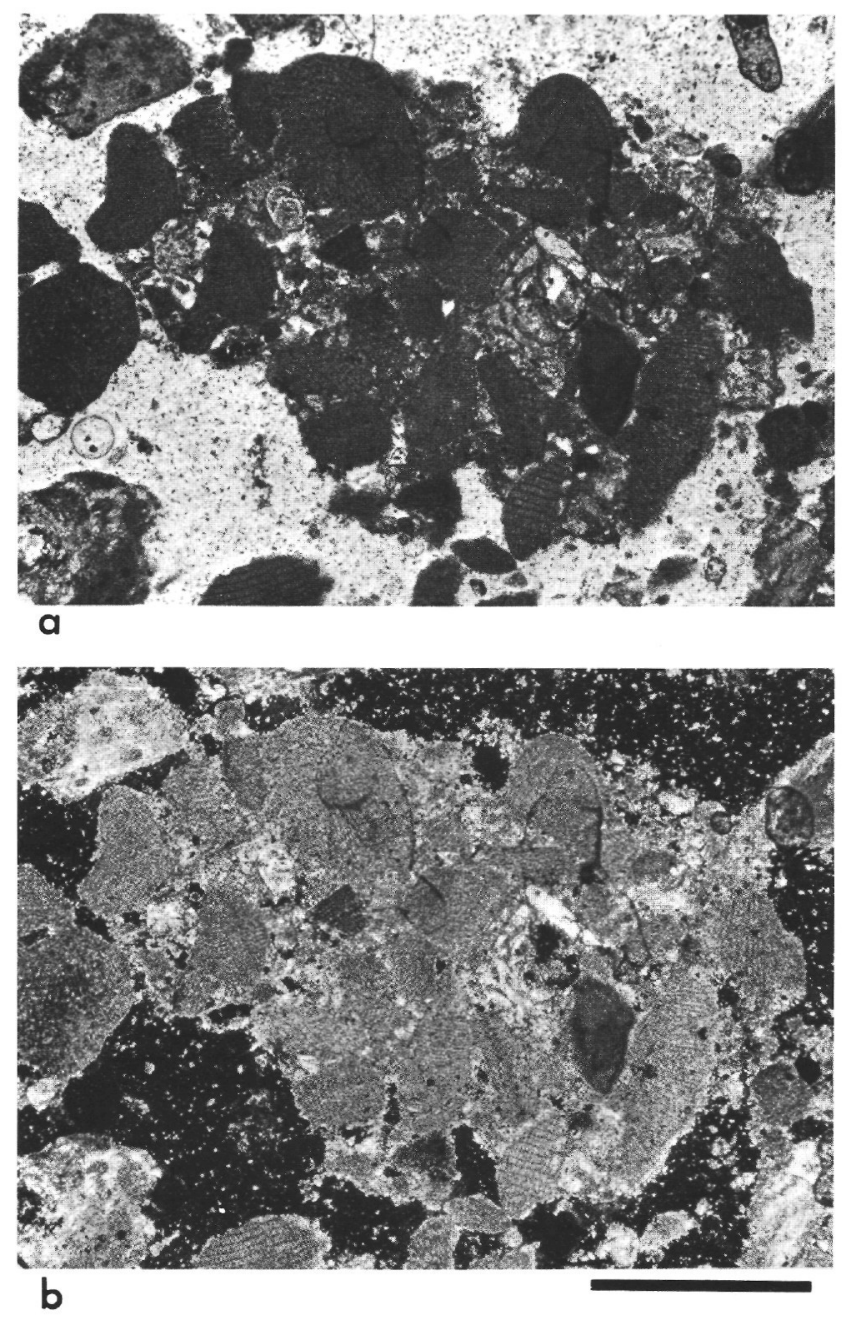

Figure 6. Grapestone. Carbonate grains, mainly coralline algae, are loosely cemented by micritic carbonate. Suiko Seamount, middle to upper Paleocene, Sample 433B-3-1, 20-60 cm. Thin sections: $A$, plane light and $B$, nicols crossed. Scale bar: 0.5 $m m$.

contact. One sample (430A-4-1, $7 \mathrm{~cm})$ has been examined in detail. This calcarenite is a washed biosparite with a small admixture of altered volcanic fragments (Figure 8). Carbonate particles are exclusively of shallow-water origin, and comprise branching coralline algae with some bryozoans, echinoderms, bivalves, and dissolved shell material, mainly gastropods. Foraminifers are mainly miliolids; larger foraminifers are rare or absent. In contrast to Suiko and Nintoku Seamounts, ooids and a few dasyclad algae do occur here (Figure 8; Plate 3, figure 8 ). The ooids are 0.3 to $0.6 \mathrm{~mm}$ in diameter. Their cortex consists of radially arranged neomorphic calcite crystals, and measures between 0.3 and $0.1 \mathrm{~mm}$. The core is generally formed by bioclasts, usually fragments of coralline algae, sometimes by calcite-filled aragonite molds, and rarely by altered volcanic debris. Corals are absent.

\section{Kōkō Seamount, Site 308}

The sediments of the lower Eocene limestone cap of Kōkō Seamount, recovered during Leg 32 of the Deep Sea Drilling Project, have been described in detail by Matter and Gardner (1975). They consist of some 60 meters of well-cemented biogenic volcanic sandstone (Core 308-4) overlain by biogenic volcanic silt (Cores 308-2 and 308-3) and uncemented palagonite-rich volcanic silt and mud (Core 308-1). The microfacies of the basal biogenic volcanic sandstone (Core 308-4) is most similar to the calcite-cemented volcanic arenites and fine rudites of Nintoku Seamount. Well-rounded, sand-sized volcanic rock particles and different types of skeletal fragments are cemented by fibrous and blocky calcite. The skeletal fragments include benthic foraminifers, bryozoans, plates of Halimeda, and minor amounts of dasyclad algae, mollusks, echinoderms, ostracodes, coralline algae, and solitary corals. Ooids make up about 10 to 20 percent of the particles.

The overlying biogenic volcanic silt is composed of altered volcanic material, palagonite, montmorillonite aggregates with an admixture of detrital shallow-water organisms, and rare planktonic foraminifers. All these components are set in a microsparitic matrix. The uncemented clayey silt at the top of the sequence consists of highly altered volcanic material, palagonite, montmorillonite, and feldspar, together with only very minor pelagic and shallow-water carbonate components.

\section{Environment of Deposition}

On all four seamounts, the limestones immediately overlying the volcanic edifice of the seamounts were deposited in shallow water. Further, there is evidence of subaerial eruption and exposure of the basalts, such as the thickness and vesicularity of the basalt flows, along with the presence of oxidized flow tops (site reports for Site 430, 432, and 433, this volume); the occurrence of a red, subaerially altered ash layer between basalt flows on Nintoku Seamount (Karpoff, this volume); and the stable isotopic ratios of the carbonate vein and vesicle fillings, which are interpreted as indicators of subaerial and shallow-water environments on Suiko Seamount (McKenzie, this volume). The epiclastic volcanic debris in the limestone caps of the seamounts, however, shows traces of alteration typical for submarine (palagonitization and calcite-filled embayments) rather than for subaerial exposure. Thus, any subaerial weathering and erosion products, except for the ash layer on Nintoku, must have been stripped away by erosion before deposition of the shallow-water carbonates (cf. Rex, 1967).

For all the shallow-water limestones, a high-energy depositional environment is indicated by the presence of generally well rounded volcanic rock fragments; their relatively well sorted grainstone texture; the absence of a muddy matrix; the exclusively shallow-water nature of the skeletal fragments, which are often mechanically abraded; the frequent occurrence of algal-bryozoan nodules; and the absence or scarcity of planktonic organisms. On the basis of the bryozoan assemblage of Kōkō 


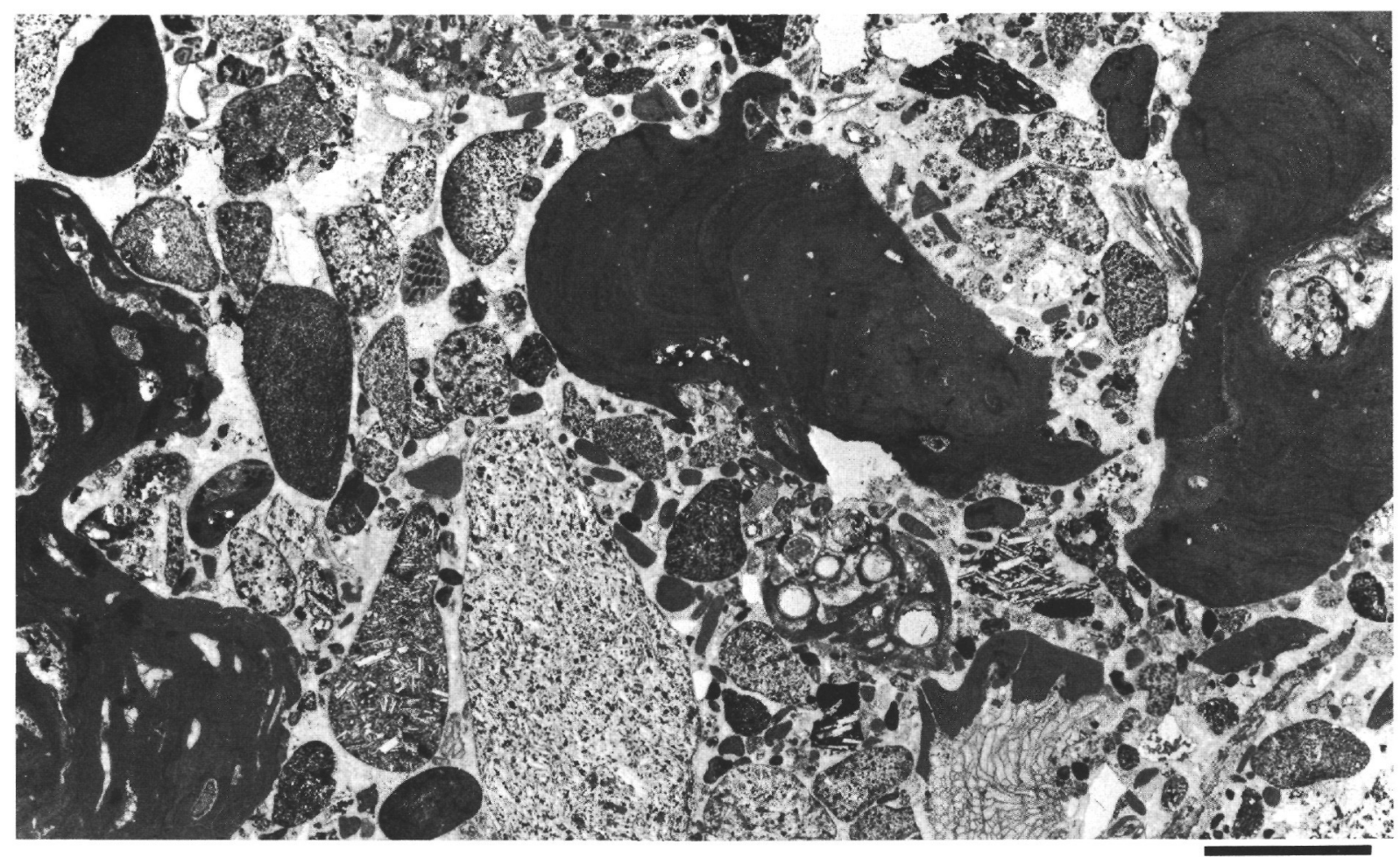

Figure 7. Bioclastic volcanic rudite containing a variety of rounded sand- to granule-sized basaltic fragments, altered in greater or lesser degree, and whole and abraded biogenic components, mainly rhodolites, coralline algae, and bryozoans. Nintoku Seamount, upper Paleocene-lower Eocene, Sample 432A-1-1, $46 \mathrm{~cm}$. Thin section: plane light. Scale bar: $2 \mathrm{~mm}$.

Seamount, Site 308, Cheetham (1975) has suggested a water depth "not much less than 60 meters." Ferrer (1975) speaks of an "inner shelf environment with sporadic communication with the open ocean" and a "water depth of 50-60 meters near shore," which is based on smaller benthic foraminiferal associations at the same site. However, Matter and Gardner (1975) interpret the abundance of shallow-water benthic foraminifers, calcareous green algae, coralline algae, and ooids as indicators of a water depth of less than 4 to 6 meters. On Kōkō Seamount, the absence of larger orbitoid foraminifers and the higher proportion of bryozoans to corals, which make up not more than 2 per cent of the sediment, was already noted by Moberly and Keene (1975). They concluded that "the shallow water of Kōkō Guyot during the early Eocene was not typical of the tropics."

The predominance of bryozoans and algae in the sediments is certainly temperature-controlled, and could be interpreted as an indicator of either paleolatitude or depositional depth. Indeed, rhodolites and coralline algae can occur at depths greater than 100 meters (Adey and Macintyre, 1973). The ooids, which are the most typical shallow-water components, make up only a minor constituent, and could be displaced from a shallower environment. If, however, the facies were only depth-controlled, we would expect also displaced coral fragments and occasional intercalations of unwinnowed sediments. Also, the abundance of micrite rims, prob- ably of algal origin, argues in favor of a shallower subtidal environment above wave base, but there is no evidence for episodic subaerial exposure. These factors together indicate water depths on the order of 20 meters or even less, if it were an open-to-the-sea fore-shore environment. The high-energy, shallow-water environment of the limestones suggests to us that the absence of corals on Ōjin, Nintoku, and Suiko seamounts, the absence of ooids and the scarcity of green algae north of Ōjin, and the increasing predominance of bryozoans and coralline algae from Kōkō to Suiko, are not primarily controlled by depth, but reflect colder waters, as predicted by the biofacies model of Schlanger and Konishi $(1966,1975)$.

\section{CARBONATE MINERALOGY}

Routine X-ray diffraction scans between $2 \theta$ values of $25^{\circ}$ and $35^{\circ}$ were made to determine the carbonate mineralogy of the samples prepared for stable isotopic analysis. All of these carbonate sediments are composed of low-magnesium calcite. The magnesium concentrations were calculated to be less than 5 per cent, from the measured shifts in the $d_{211}$ peak. Neither aragonite nor high-magnesium calcite was recorded. The modern counterparts of the predominant skeletal and nonskeletal components in the sediments contain high-magnesium calcite (bryozoans, coralline algae, and miliolids) and aragonite (codiacean algae, ooids, and gastropods) (Milliman, 1974). The total absence of these 

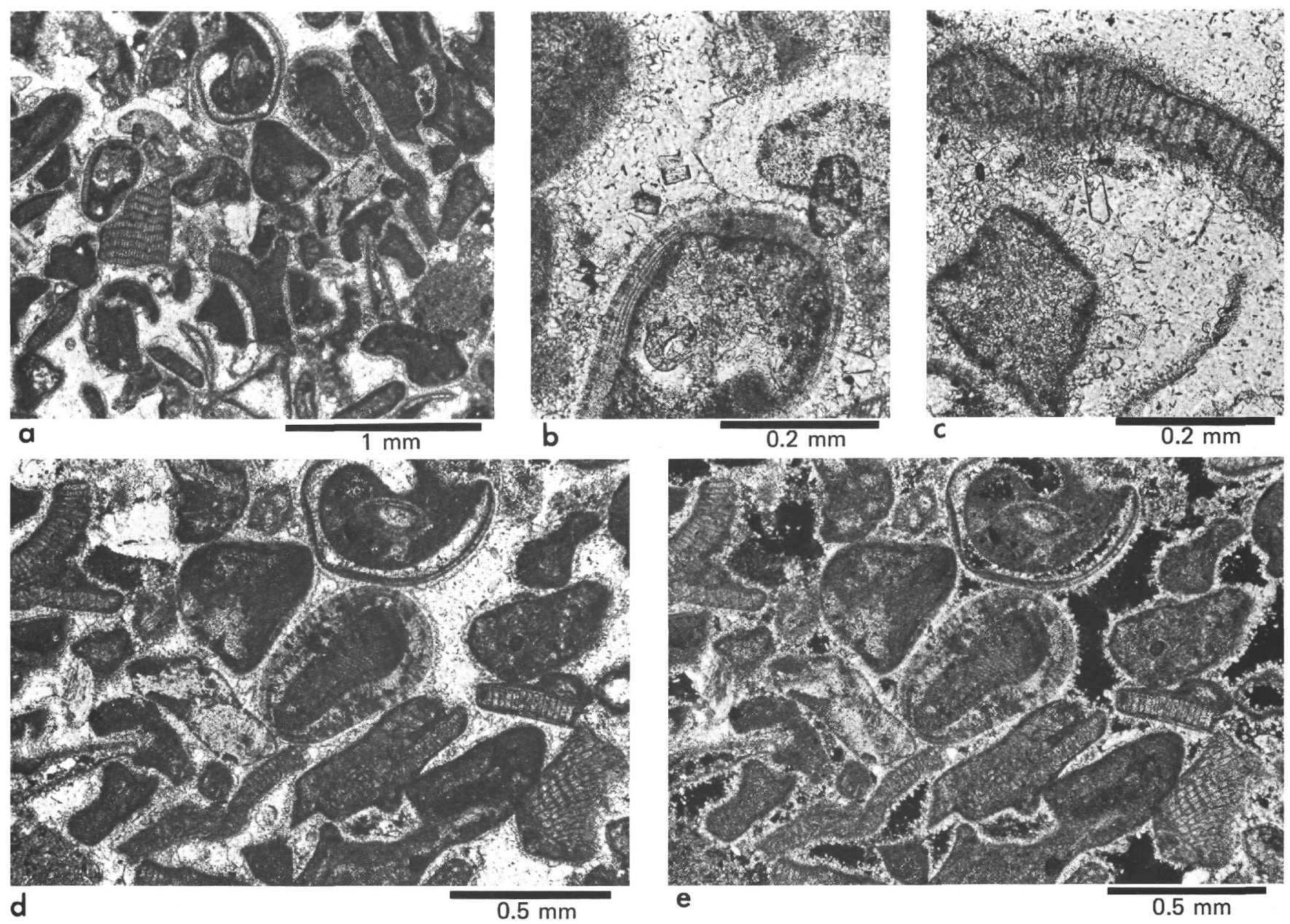

Figure 8. Shallow-water limestone, upper Paleocene to middle Eocene, Ojin Seamount, Sample 430A-4-1, $7 \mathrm{~cm}$. Shallow-water calcarenite with skeletal fragments, mainly branching coralline algae, calcite-filled molds of molluscan shells, ooids, and superficial ooids. The cores of the ooids are mainly skeletal fragments, such as coralline algae or calcite-filled molds of previously aragonitic skeletons, and rare volcanic fragments. The particles are cemented by fibrous palisade rim cement, which is in optical continuity with pre-existing radial fabrics like ooids $(b$ and $c)$, and by later dog-tooth calcite, syntaxial overgrowth on echinoderms (b), phillipsite (c), and clinoptilolite (b). Thin sections: Figures a to d, pane light; Figure e, nicols crossed. Scale bars: Figure a, 1 mm; Figures b and c, $0.2 \mathrm{~mm}$; Figures $d$ and $e, 0.5 \mathrm{~mm}$.

minerals in the examined sediments indicates the extent of diagenetic alteration.

The strontium content of the shallow-water carbonates is extremely low, particularly when compared with the content of the immediately overlying volcanic sands (Karpoff, this volume). This strontium depletion could also be a reflection of carbonate diagenesis. With the dissolution of aragonite and the reprecipitation of calcite, the large ionic radius of the strontium ions makes them less prone to enter the calcite lattice, and they are released to the pore solutions.

\section{STABLE-ISOTOPE ANALYSES}

Carbonate samples were chosen systematically to evaluate the stable isotopic content of shallow-water sediments from the Emperor Seamounts. In the case of Kōkō, Ōjin, and Nintoku seamounts (Site 308, 430, and 432 , respectively), the recovery was poor, and only a limited number of analyses was possible. Recovery of sediments from Suiko Seamount, (Site 433) was often restricted to core-catcher samples, but the successful drilling at this site yielded abundant samples for a more extensive isotopic survey. The "reef" limestones from Kammu Seamount are dredged samples.

The carbonate sediments were analyzed for their stable isotope content according to the traditional method for the release of $\mathrm{CO}_{2}$ gas (McCrea, 1950). The gas from bulk samples was analyzed with a Micromass 903, a triple-collector mass spectrometer, and appropriate correction factors were made (Craig, 1957). The results are expressed as per mil deviations from the PDB isotopic standards: $\delta=\left[\left(R_{\text {sample }} / R_{\text {standard }}\right)-1\right] \times$ $10^{3}$ where $R$ is ${ }^{13} \mathrm{C} /{ }^{12} \mathrm{C}$ or ${ }^{18} \mathrm{O} /{ }^{16} \mathrm{O}$. The precision of the measurements, a standard deviation of the mean calculated for replicate analyses, is $\pm 0.02 \%$ for $\delta^{13} \mathrm{C}$ and $\pm 0.03 \%$ for $\delta^{18} \mathrm{O}$. Samples of bryozoan-algal 
sand, carbonate mud, algal nodules, and cemented calcarenite were analyzed. The results are tabulated in Table 1.

The most striking aspect of the isotopic results from the relatively more abundant shallow-water sediments from Suiko Seamount (Hole 433A, Cores 7 to 19, Hole 433B, Cores 2 to 4, and Hole 433C, Core 3 ) is the lack of variability between samples of unconsolidated mud and sand and cemented calcarenite. The average $\delta^{18} \mathrm{O}$ value is $0.29 \pm 0.23 \%$; the average $\delta^{13} \mathrm{C}$ value is $0.98 \pm$ $0.25 \%$. This isotopic homogeneity is interpreted as an indicator of the pervasiveness of diagenesis. When the stable isotopic ratios of selected samples are graphed with respect to their stratigraphic position, however, there is an apparent isotopic break in the sedimentary column, which occurs between Cores 11 and 12 (Figure 2). A color change from yellow to gray was also observed at this point. The gray carbonates have slightly more depleted carbon-13 and oxygen-18 contents than the yellow carbonates. This isotopic difference may denote the upward migration of solutions from the underlying basalts. Sample 433B-4-1, 35-36 cm is a pure calcite cement filling a vein directly below the sediment/basalt contact (Figure 3) and has the isotopic ratios $\delta^{18} \mathrm{O}=-0.44 \%$ and $\delta^{13} \mathrm{C}=+0.98 \%$. This ce-

TABLE 1

Stable Isotope Data

\begin{tabular}{|c|c|c|c|}
\hline $\begin{array}{l}\text { Sample Number } \\
\text { (Interval in } \mathrm{cm} \text { ) }\end{array}$ & $\delta^{18} \mathrm{OPDB}_{\mathrm{PD}}$ & ${ }^{8}{ }^{13} \mathrm{C}_{\mathrm{PDB}}$ & Sample description \\
\hline \multicolumn{4}{|c|}{ Suiko Seamount - Leg 55, Site 433} \\
\hline $\begin{array}{c}433 \mathrm{~A}-6-1,50-53 \\
6-3,140-144 \\
6-6,64-66 \\
6-6,124-126 \\
6-7,12-14\end{array}$ & $\begin{array}{l}+1.28 \\
+1.13 \\
+1.48 \\
+1.15 \\
+1.03\end{array}$ & $\begin{array}{l}+0.73 \\
+0.66 \\
+0.94 \\
+1.52 \\
+2.02\end{array}$ & $\begin{array}{l}\text { Light gray calcareous ooze } \\
\text { Light gray calcareous ooze } \\
\text { Light gray calcareous ooze } \\
\text { White chalk } \\
\text { White chalk }\end{array}$ \\
\hline $\begin{array}{l}6-7,38-40 \\
6, C C \\
7-2,70-72 \\
8-1,126-127 \\
9-6,49-51\end{array}$ & $\begin{array}{l}+0.04 \\
+0.05 \\
+0.48 \\
+0.42 \\
+0.42\end{array}$ & $\begin{array}{l}+1.46 \\
+1.15 \\
+1.42 \\
+1.36 \\
+1.32\end{array}$ & $\begin{array}{l}\text { White chalk with volcanic mud } \\
\text { Volcanic mud } \\
\text { Yellow muddy carbonate sand } \\
\text { Yellow muddy carbonate sand } \\
\text { Yellow muddy carbonate sand }\end{array}$ \\
\hline $\begin{array}{l}10-3,55-57 \\
10-4,97-100 \\
11, \text { CC }(11-13) \\
12-1,70-72 \\
13-1,15-17\end{array}$ & $\begin{array}{l}+0.60 \\
+0.76 \\
+0.08 \\
+0.60 \\
+0.29\end{array}$ & $\begin{array}{l}+1.18 \\
+1.14 \\
+1.00 \\
+1.31 \\
+0.84\end{array}$ & $\begin{array}{l}\text { Yellow muddy carbonate sand } \\
\text { Yellow algal nodule } \\
\text { Yellow algal nodule } \\
\text { Yellow-gray carbonate sand } \\
\text { Gray carbonate sand }\end{array}$ \\
\hline $\begin{array}{l}14, \mathrm{CC}(0-2) \\
15, \mathrm{CC}(0-2) \\
16, \mathrm{CC}(0-4) \\
17, \mathrm{CC}(4-6) \\
18, \mathrm{CC}(0-3)\end{array}$ & $\begin{array}{l}+0.34 \\
+0.12 \\
+0.18 \\
+0.04 \\
-0.12\end{array}$ & $\begin{array}{l}+0.89 \\
+0.94 \\
+0.94 \\
+0.58 \\
+0.56\end{array}$ & $\begin{array}{l}\text { Gray algal nodule } \\
\text { Gray algal nodule } \\
\text { Gray carbonate sand } \\
\text { Gray algal nodule } \\
\text { Gray semi-lithified calcarenite }\end{array}$ \\
\hline $19, \mathrm{CC}(20-22)$ & +0.06 & +0.74 & Gray carbonate sand \\
\hline $\begin{array}{r}433 \mathrm{~B}-2-1,0-10 \\
4-1,17-18 \\
4-1,28-29 \\
4-1,35-36 \\
4-1,37-38\end{array}$ & $\begin{array}{l}-0.02 \\
+0.32 \\
+0.41 \\
-0.44 \\
+0.32\end{array}$ & $\begin{array}{l}+0.75 \\
+0.80 \\
+0.90 \\
+0.98 \\
+1.08\end{array}$ & $\begin{array}{l}\text { Gray carbonate mud } \\
\text { Calcite-cemented calcarenite } \\
\text { Calcite-cemented calcarenite } \\
\text { Calcite cement } \\
\text { Calcite-cemented calcarenite }\end{array}$ \\
\hline $433 \mathrm{C}-3-2,101-103$ & +0.17 & +0.96 & Gray carbonate sand, rich in volcanic material \\
\hline \multicolumn{4}{|c|}{ Nintoku Seamount - Leg 55 Site 432} \\
\hline $432 \mathrm{~A}-2-1,3-5$ & -0.39 & +0.11 & Calcareous conglomerate \\
\hline \multicolumn{4}{|c|}{ Ōjin Seamount - Leg 55 Site 430} \\
\hline $\begin{array}{c}430-1, C C(7-8) \\
2, C C(7-8) \\
3, C C(0-3) \\
4-1,20-23\end{array}$ & $\begin{array}{l}+0.44 \\
-0.86 \\
-0.22 \\
-0.94\end{array}$ & $\begin{array}{l}+2.00 \\
+1.88 \\
+1.16 \\
-0.74\end{array}$ & $\begin{array}{l}\text { White algal nodule } \\
\text { Calcite-cemented calcarenite } \\
\text { Calcareous siltstone } \\
\text { Calcite-cemented calcarenite }\end{array}$ \\
\hline \multicolumn{4}{|c|}{ Kōkō Seamount - Leg 32 Site 308} \\
\hline $\begin{array}{l}308-2, \mathrm{CC} \\
\quad 4-1,112-113 \\
\quad 4-1,142-143\end{array}$ & $\begin{array}{l}-0.80 \\
-1.02 \\
-1.07\end{array}$ & $\begin{array}{l}+0.95 \\
+0.20 \\
+0.45\end{array}$ & $\begin{array}{l}\text { Biogenic volcanic silt } \\
\text { Biogenic volcanic sandstone } \\
\text { Biogenic volcanic sandstone }\end{array}$ \\
\hline \multicolumn{4}{|c|}{ Kammu Seamount - Aries Leg 7 Dredge 54-3 (SIO) } \\
\hline $\begin{array}{r}54-3,1 \\
3,2\end{array}$ & $\begin{array}{l}+2.05 \\
+1.37\end{array}$ & $\begin{array}{l}+1.54 \\
+1.00\end{array}$ & $\begin{array}{l}\text { "Reef" limestone } \\
\text { "Reef" limestone }\end{array}$ \\
\hline
\end{tabular}

ment is the same as the later-stage blocky calcite which fills pore spaces in the overlying calcarenite, and is discussed later under Carbonate Diagenesis. The overall extent of isotopic exchange that occurred during diagenesis is seen in the positive $\delta^{18} \mathrm{O}$ ratios of the bryozoan-red algal sands. For comparison, modern coralline algae are reported to have a range of $\delta^{18} \mathrm{O}$ ratios between -1.0 and $-6.0 \%$ (Milliman, 1974).

Interpretations of the environment of carbonate diagenesis are facilitated by the calculation of isotopic re-equilibration temperatures. In this study of ageprogressive sediments from a linear seamount chain, isotopic temperatures could have a dual significance. The $\delta^{18} \mathrm{O}$ ratios of the carbonates can record temperature changes resulting from the subsidence of a seamount into cooler waters and any temperature changes that may have occurred with time along the seamount chain. Isotopic temperatures were calculated using the equation reported in Shackleton (1973) and $-1.2 \%$ for the $\delta^{18} \mathrm{O}$ ratio of sea water, which represents Tertiary preglacial sea water (Shackleton and Kennett, 1975).

At Site 433 , the oxygen- 18 content of the carbonate sediments was measured across the boundary between the shallow-water sediments and the deep-water pelagic sediments (Hole 433C, Core 6). These data are graphed in Figure 9. The average $\delta^{18} \mathrm{O}$ ratio for all of the analyzed middle to upper Paleocene shallow-water sediments is plotted below the Oligocene-Eocene hiatus. The isotopic temperatures, which correspond to this $\delta^{18} \mathrm{O}$ value, range between $10^{\circ}$ and $12^{\circ} \mathrm{C}$, and correlate with the bottom water temperatures that prevailed in the Paleocene North Pacific (Savin et al., 1975). Although the isotopic temperature does not indicate absolute depth, the calculated temperatures strongly suggest that re-equilibration did not occur in warm, potentially evaporated surface waters or in meteoric waters or as a result of hydrothermal activity, but in the transition zone between the surface and deep waters. In this zone, the temperature decreases rapidly with depth. The water mass underlying the surface waters is designated intermediate waters (Sverdrup et al., 1942).

An isotopic temperature transition toward cooler waters was recorded in the upper lower Miocene volcanic mud-chalk-calcareous ooze sequence (Figure 9). The isotopic temperature drop of $6^{\circ} \mathrm{C}$ recorded in the carbonate sediments at Suiko probably does not represent a climatic deterioration. The isotopic temperatures resulted from re-equilibration after Suiko Seamount had subsided into deeper cooler waters. The apparent isotopic temperature transition could depict continued re-equilibration as the seamount subsided into even cooler waters in the late early Miocene.

We undertook a comparative isotopic study of the available calcite-cemented calcarenites from the four DSDP sites and one dredge site along the Emperor Seamount chain, assuming that the calcarenites were formed during equivalent periods in the development and subsidence history of each seamount. Petrographic evidence, described below, indicates that the carbonate diagenesis of the limestones may have begun with aragonite dissolution in the phreatic zone, but sub- 


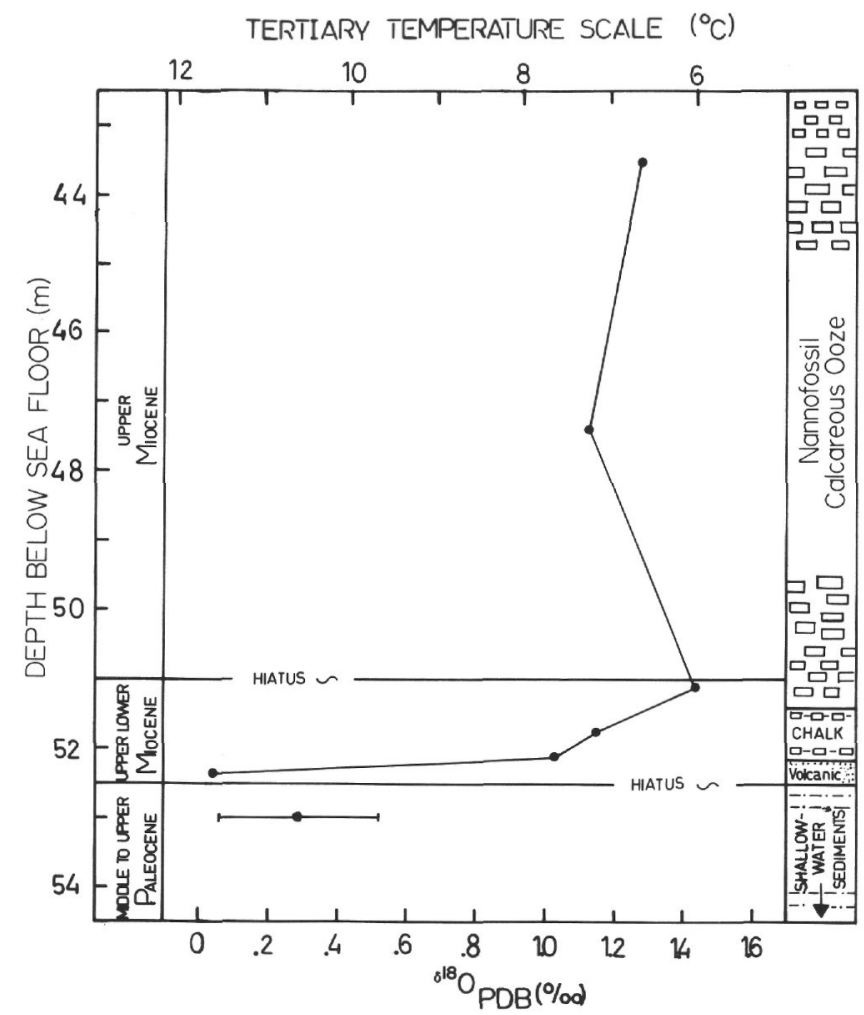

Figure 9. The change in $\delta^{18} \mathrm{O}$ ratios across the transition from shallow-water reef sediments to pelagic sediments from Suiko Seamount (Hole 433C) is graphically shown. The Tertiary temperature scale is based on calculations using a preglacial isotopic ratio for sea water (see text). The isotopic temperature of $10^{\circ}$ to $12^{\circ}$ for the shallow-water sediments represents the temperature of diagenesis.

marine diagenesis certainly occurred with subsidence. Therefore, as concluded from the isotopic data assembled for Suiko Seamount, we likewise assumed, for the other seamounts, that the bulk of the isotopic re-equilibration occurred after the seamounts subsided into the zone of intermediate waters.

In Figure 10, the average $\delta^{18} \mathrm{O}$ ratio for cemented calcarenites from each DSDP site is plotted against the potassium-argon age of its respective seamount. A straight line can be drawn to connect the data points. The corresponding isotopic temperatures could imply that diagenesis and lithification of the calcarenites occurred in progressively warmer waters. This could have been the situation if a northward shift of isotherms more than compensated for the northward movement of the seamounts. Alternatively, the isotopic linearity could reflect the degree of incomplete isotopic re-equilibration with the cold intermediate waters. Because the original carbonate phases in all the samples have been recrystallized to low-magnesium calcite, the latter explanation for the linearity seems the less likely.

The fossil ages of the calcarenites range from middle to upper Paleocene for Suiko Seamount (site report for Site 433, this volume), upper Paleocene to lower Eocene for Nintoku and Ōjin Seamounts (site reports for Sites

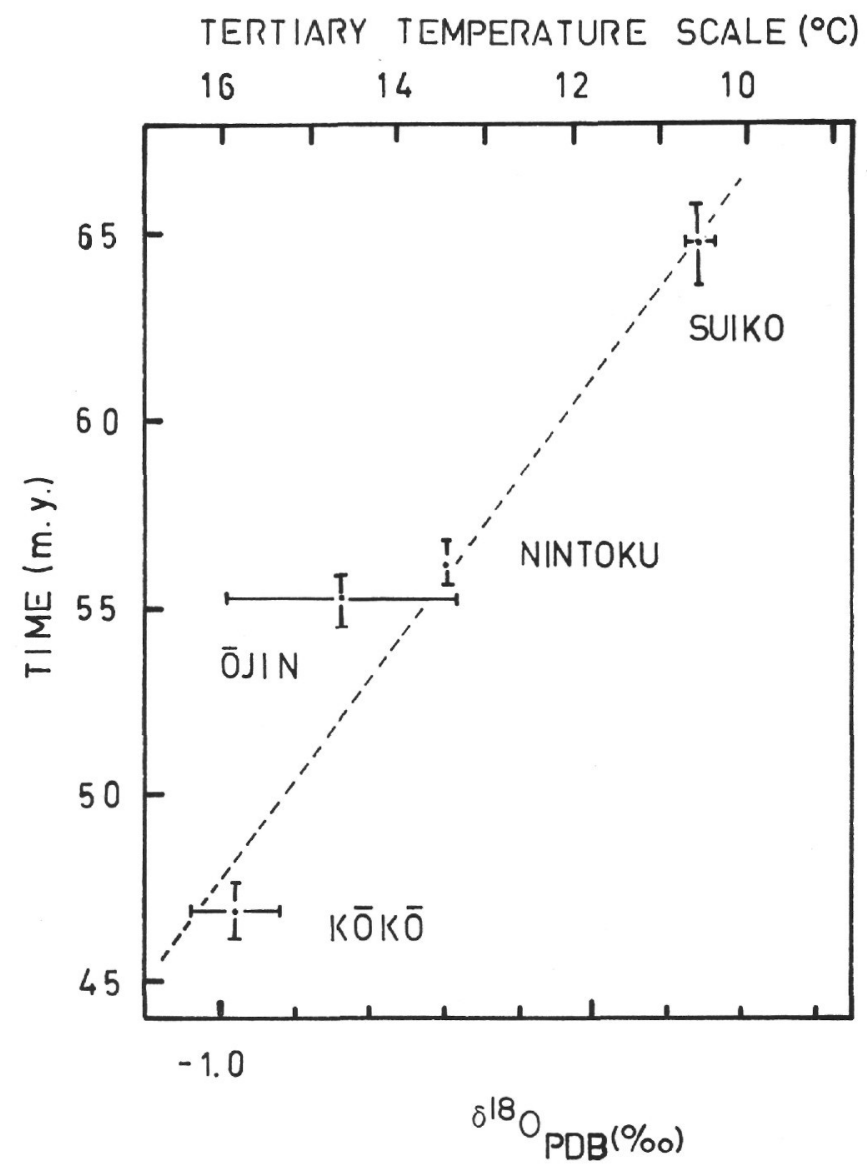

Figure 10. The average $\delta^{18} \mathrm{O}$ ratios for cemented calcarenites from four Emperor seamounts are plotted against the potassium-argon ages of the seamounts: Suiko, Nintoku, and Ōjin (Dalrymple et al., this volume) and Kōkō (Dalrymple and Clague, 1976). The Tertiary temperature scale is based on calculations using a preglacial isotopic ratio for sea water (see text). The isotopic temperature for each calcarenite represents the temperature of diagenesis.

430 and 432, this volume), lower Eocene for Kōkō Seamount (Matter and Gardner, 1975), and upper Eocene for Kammu Seamount (Sach, quoted in Clague and Jarrard, 1973). During Paleocene to middle Eocene time, surface water temperatures in the North Pacific were warm, and appear to have remained fairly constant, although there are indications in some of the data for a warming trend beginning at a time corresponding to the Cretaceous/Paleocene boundary and continuing into the Eocene (Figure 11). A corresponding but significantly larger warming trend was measured for the bottom waters. Further, it is interesting that after the end of the middle Eocene the temperature of both bottom and surface waters in the North Pacific dropped dramatically (Savin et. al., 1975).

Figure 11 shows the isotopic temperature curves for North Pacific surface and bottom waters. The curves were generated from isotopic studies on Cretaceous to Oligocene planktonic and benthic foraminifers. Bars representing the oxygen-18 isotopic composition of the 
Emperor Seamount calcarenities are superimposed, in accordance with their respective fossil ages, upon the foraminifers curves. The isotopic temperatures for the diagenesis of the calcarenites appear to follow the foraminiferal paleotemperature curves. In particular, the results for Kammu Seamount reflect the very steep cooling recorded between the upper Eocene and lower Oligocene. Also, the linearity shown in Figure 10, compiled for Suiko, Nintoku, Ōjin, and Kōkō seamounts, reflects the warming trend seen in the foraminferal data from the Cretaceous to the middle Eocene, i.e., the participation with time of increasingly warmer intermediate waters in the carbonate diagenesis.

To obtain isotopic compositions similar to the ageequivalent values from the foraminifer curves, diagenesis and isotopic exchange must have occurred very early, soon after the end of sedimentation. Therefore, the initial subsidence of the seamount must have been rapid and brought the sediments into the cooler intermediate waters in a relatively short geologic time. Winterer (1977) concludes that in the first 5 million years of the development of oceanic seamounts, rapid build-up of the volcanic pile and very rapid subsidence occur. Following this period, subsidence rates are similar to those which would be expected for the underlying lithospheric crust. After the re-equilibration, the isotopic composi-

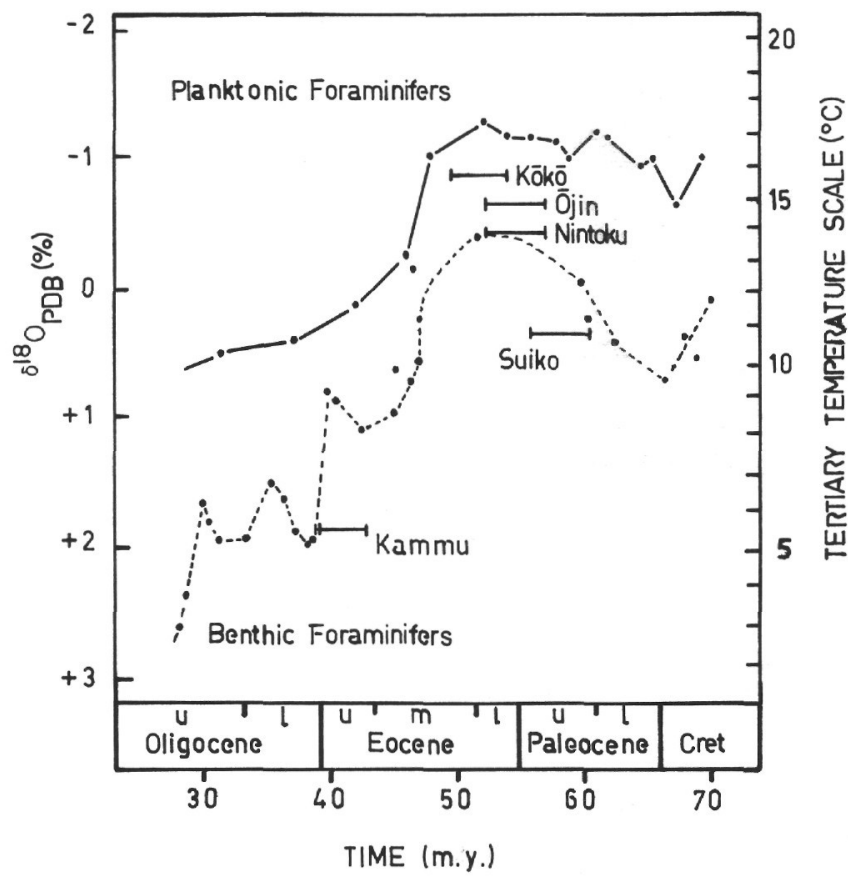

Figure 11. This illustration of Cretaceous to Oligocene isotopic temperature curves for the North Pacific is adapted from a figure by Savin (1977). The Tertiary temperature scale is for the benthic foraminifers, and was calculated using a $\delta^{18} O$ ratio for sea water of $-1.00 \%$. For comparison, the average $\delta^{18} \mathrm{O}$ ratios of the Emperor Seamount cemented calcarenites are superimposed, according to their respective fossil ages, on the Savin curves. tion of the low-magnesium calcite was firmly set, and further isotopic exchange or addition was minimal. Otherwise, the isotopic pattern recorded along the Emperor Seamount chain would have been obliterated by further re-equilibration, and the isotopic temperature of all the calcarenites would correspond to the temperature of the modern intermediate waters in the North Pacific.

\section{DIAGENESIS}

According to the assemblage of skeletal components in the shallow-water limestones, the original calcium carbonate phases must have consisted of a mixture of high-magnesium calcite and aragonite. No aragonite or high-magnesium calcite has been detected by X-ray diffraction, so these metastable phases must have been converted to stable, low-magnesium calcite. The diagenetic processes involved in the stabilization and lithification of these carbonate sediments include the alteration of carbonate grains, mainly the dissolution of aragonitic particles, and cementation by (1) early autochthonous calcite and (2) later alloch thonous calcite and zeolites. The diagenetic fabrics of the carbonates observed in the limestones of Suiko, Nintoku, and Ōjin seamounts, and the diagenetic processes leading to their formation, are very similar to those described for Kōkō Seamount by Matter and Gardner (1975). These fabrics and processes will therefore be illustrated only briefly, whereas emphasis is placed on the zeolite cementation, which is rather uncommon in shallow-water carbonate rocks.

\section{Carbonate Diagenesis}

\section{Alteration of Carbonate Grains}

The alteration or preservation of a carbonate grain during diagenesis depends upon its original mineralogy. Aragonite tends to be dissolved or transformed by neomorphic processes into coarser grained calcite. Highmagnesium calcite is replaced by or stabilized to lowmagnesium calcite.

The presence of aragonite was not detected by X-ray diffraction. Its former presence, however, is established by abundant traces of whole or broken and abraded shell fragments of mollusks and plates of codiacean algae. Some of these might have been dissolved without leaving a trace, but others have been confined in micrite envelopes, which were not destroyed by the subsequent dissolution of aragonite (Bathurst, 1964, 1966). These micrite rims now outline calcite-cemented molds of gastropods and other molluscan fragments (Plate 2). Some of the rims have collapsed and occur as displaced fragments. In SEM photographs, they appear as extremely thin micrite seams, only a few micrometers wide, from which early calcite cements grew into pore spaces (Plate 2 figures 4-6). The micrite rims most probably were originally aragonite or high-magnesium calcite. However, their stabilization to low-magnesium calcite seems to have taken place in an organic matrix without an observable breakdown of the texture. 
In a few instances, aragonite may have escaped dissolution, but it is quantitatively too little to be detected by $\mathrm{X}$-ray diffraction. Plate 3 , figures $1-3$ show a molluscan fragment surrounded by a micrite envelope in which part of the original fabric is still preserved. Most of the skeleton has been dissolved and the resulting mold is partially filled in by calcite cement. Without the aid of a color test, it is uncertain if the part of the fragment which is texturally unaltered is still aragonite or if neomorphic calcite replaced the shell without observable changes.

Plates of codiacean algae and fragments of dasyclads (Site 430) are also enveloped by micrite rims, Micrite, originally aragonite (Glover and Pray, 1971) or highmagnesium calcite (Winland, 1971), fills also the utricles of the codiacean plates (Plate 3, figures 4-7) and the pores of the dasyclad algae (Plate 3 , figure 8 ). The original skeletal material is replaced by micrite or neomorphic microspar (Plate 3, figures 5 and 6) or dissolved and the mold eventually cemented by calcite (Plate 3, figures 4 and 7). In the sediments from Kōkō Seamount, Matter and Gardner (1975, their Plate 1, figure 2) have observed the progressive replacement of micrite by calcite spar, which resulted in obliteration of the original internal structure of the algae by a finely crystalline, blocky mosaic of microspar and calcite cement. Large patches of microspar and sparry calcite cement obviously originated from the replacement and dissolution of larger aragonitic skeletons (Plate 8, figures 1 and 2). Micrite rims and/or former skeletal structures are recognizable as ghosts in neomorphic calcite, whereas much of the intra- and interparticle pore space is cemented by sparry calcite and phillipsite (Plate 8, figures 3-6).

Ooids occur as a minor constituent only on Ōjin Seamount (Site 430). As in the case of the ooids from Kōkō Seamount described by Matter and Gardner (1975) and those from Ita Matai described by Hesse (1973), the original aragonite of the ooids has been replaced by radially arranged calcite (Figure $8, \mathrm{~d}$ and e). This replacement took place without an intervening cavity stage or textural breakdown. For a discussion of the processes involved, we refer the intended reader to the papers cited.

The skeletal microstructure of coralline algae is always well preserved, and there are no observable textural alterations involved in the stabilization from highmagnesium to low-magnesium calcite. This led Land (1967) to suggest that magnesium is lost by incongruent dissolution and replaced by calcium. Also, the original high-magnesium calcite in echinoderm and foraminiferal skeletons has been stabilized to low-magnesium calcite without an intervening cavity stage (Figure 8; Plate 7 , figures 8 and 9 ).

\section{Calcite Cements}

In the generally uncemented shallow-water carbonate sands of Suiko Seamount, some smaller carbonate grains are loosely cemented by micritic carbonate to form irregular sand-sized grapestone lumps and aggre- gates (Figure 6). Similar to the shallow-water grapestones of Holocene carbonates, these composite particles have been bound together penecontemporaneously, possibly in a subtidal mucilaginous organic matrix (Bathurst, 1971). Calcite occurs as sparry intraparticle cement in bryozoan skeletons, as infill of micrite and microspar in red algae and in grapestone aggregates.

In the cemented calcarenites, two kinds of calcite cements are present. They line inter- and intraparticle pores and are identical to the cements from Kōkō Seamount described by Matter and Gardner (1975). The first generation is a continuous rim of palisade cement made up of fibrous crystals; the second generation consists of blocky "dog-tooth" calcite sometimes intergrown with phillipsite (Plates 4-6).

The palisade rim cement consists of elongate, subparallel radiating calcite crystals with euhedral terminations. As observed by Matter and Gardner (1975, p. 526), there is a correlation between substrate, crystal density, and orientation: "Where the crystals rise from a polycrystalline substrate, which provides a high nucleation rate (foraminifera, coralline algae or micrite envelopes), they are subparallel, radiate very regularly and increase in length toward the center of the pore". On substrates with a radial fabric (radial calcite in ooidal coatings, ostracodes) the rim cement grows in continuous optical orientation. The length of the crystals is variable, and ranges from about 10 up to 150 $\mu \mathrm{m}$ with an average between 20 and $40 \mu \mathrm{m}$. The long sides of the crystals are steep scalenohedral faces which distally often are curved; the crystals terminate with two sets of rhombic faces which are rotated $60^{\circ}$ against each other (Schroeder, 1973; Matter and Gardner, 1975).

The crystals of the palisade rim increase in size toward the center of the pore. Smaller grains rooted on the particles serve as a substrate for larger fibrous crystals (Plate 5, figure 6).

The second generation of calcite consists of "dogtooth" calcite crystals, up to $200 \mu \mathrm{m}$ long. They also show steep scalenohedral faces along their long sides, and terminate with flat rhombohedral faces (Plate 6, figures 1-3). They grow tangentially or obliquely to their substrate and with random orientation from sites of nucleation along the pore walls, which are already covered by the palisade rim cement. Probably there was a discontinuity in the growth of calcite cements, and it appears that the second generation of larger crystals grew at a much slower rate. They also grew contemporaneously with phillipsite (and at Hole 430A with clinoptilolite), which was precipitated in the pore space.

In the volcanic sandstones overlying the basaltic rocks at Hole $432 \mathrm{~A}$, the second-generation calcite cement postdates an earlier rim cement of smectite (Plate 6 , figure 6). At Site 433, near the contact with the underlying basalt (Sample 433B-4-1, 30-37 cm), the calcite crystals of the second generation grow together and form a blocky mosaic of anhedral calcite occluding the entire pore space (Plate 6, figures 4 and 5). Here, straight crystal boundaries and enfacial junctions, 
typical for void-filling cements (Bathurst, 1964, 1971), are observed.

Echinoderm debris, if not protected by micrite envelopes, is largely overgrown by syntaxial calcite cements (Evamy and Shearman, 1965, 1969). These crystals must have grown at a much faster rate than the slowly growing "dog-tooth" crystals, as demonstrated by the large calcite poikilotopes surrounding other carbonate grains and slowly growing zeolites (Plate 7, figures 8,9). Sometimes the overgrowths are preceded by a discontinuous border of palisade rim cement. Such an early cement probably could develop where the echinoderms were still covered by an organic coating. Intergrowth between zeolites and second generation "dog-tooth" calcite suggests that the syntaxial rim cement is partly contemporaneous with the second phase of cementation. No discontinuity has been discovered in the growth of syntaxial cement on echinoderms with conventional petrographic microscopy.

In larger mosaics of microspar and sparry calcite, distinguishing between neomorphic calcite and cement is not always easy. Relic structures ("ghosts") of skeletons and micrite rims suggest a neomorphic origin for part of the calcite micrite and microspar. On the other hand, the importance of void-filling cement in these fabrics is shown by the occurrence of palisade rim cements in partially cemented patches and the contemporaneous precipitation of zeolite cements (Plate 8, figures 1-7 and 9; cf. also Matter and Gardner, 1975, their Plate 7, figure 2). Fibrous gypsum has been observed in one instance as a cement binding together coralline algae (Sample 433B-3-1, 20-60 cm).

As pointed out by Matter and Gardner (1975), the cemented calcarenites of the limestone caps of the Emperor Seamounts have reached the diagenetic stage V of Land et al. (1967). Indeed, high-magnesium calcite has lost its magnesium, aragonite has been almost completely dissolved, and much of the primary and secondary pore space is now occupied by low-magnesium calcite cement. Contrary to Matter and Gardner (1975), we think that we can distinguish two generations of calcite cement separated by a discontinuity of calcite precipitation, except perhaps in the case of the syntaxial overgrowth on echinoderms.

Both generations of cement are thought to have formed in a subaquatic environment. The first generation of palisade rim cement generally forms a continuous crust of intra- and interparticle cement. There are no indications of cementation in the vadose zone. Indeed, the crystal shape of this rim cement is very similar to that of early submarine high-magnesium calcite cements from Holocene and Pleistocene algal cup reefs in Bermuda (described by Schroeder [1972, 1973]) and from carbonate sands associated with the shallow seaward margins of barrier and atoll reefs off Belize (described by James et al. [1976]). As pointed out by Schroeder $(1972,1973)$ and by James et al. (1976) and as shown by the textural evidence presented by Matter and Gardner (1975) and in this paper, these calcites are primary precipitates which had no aragonitic precursors. This is clearly shown where palisade rim cements overlie syntaxially preexisting radial calcite fabrics and by the absence of orthorhombic symmetry. The palisade rim cements in the limestone caps of the Emperor Seamounts are now low-magnesium calcite, but Matter and Gardner, on the basis of relatively high magnesium content on the calcite (approximately 3 mole $\%$ $\mathrm{MgCO}_{3}$ ), have suggested that they were also high-magnesium calcite and, indeed, would be ancient analogs of the Holocene submarine cements in shallow-water carbonates.

There are, however, severe restrictions to relating the first-generation palisade calcites to an early submarine cementation. In the foregoing Holocene examples, highmagnesium calcite cements coexist, sometimes in the same pores, with aragonite cements (Schroeder, 1972, 1973), and sometimes they even cement aragonitic particles (James et al., 1976). The Holocene limestones have only reached the diagenetic stage II of Land et al. (1967), and it is only in the Pleistocene reef rocks, which have been exposed to meteoric waters, that aragonite is altered to calcite on the way to diagenetic stage IV (Schroeder, 1973). In fact, aragonite appears to be fairly stable in sea water, and is unaltered in many Tertiary carbonates of Pacific atolls which were not exposed to meteoric waters (Schlanger, 1963). In these Tertiary sequences drilled on Eniwetok and Bikini atolls, there are alterations of unconsolidated and only lightly cemented carbonates, which still include unaltered primary aragonite, with well-cemented limestones which have attained diagenetic stage $\mathrm{V}$ and can be correlated with times of subaerial emergence and the development of a phreatic fresh-water lens below the atoll (Schlanger, 1963).

In the cemented limestone caps of the Emperor Seamounts, all aragonite has been dissolved (diagenetic stage V), and the palisade rim cement postdates - at least in part - the replacement of ooids by calcite and the dissolution of skeletal aragonite. We may, therefore, interpret the palisade rim cement as an essentially autochthonous cement derived from the dissolution of aragonite. In analogy with the diagenetic evolution in Cenozoic shallow-water carbonates, one may suspect that these processes of aragonite solution/calcite precipitation took place under the influence of meteoric waters. In the total absence of features diagnostic for the vadose environment, such as meniscus (Dunham, 1971) or gravitational (Purser, 1969) cement, aragonite solution and calcite cementation would have taken place in a phreatic environment, and could be correlated with the early phase of seamount evolution when much of the volcanic edifice was still emergent and a fresh-water lens existed below the island. Such a situation is also suggested by reflection seismic data showing that the drilling site is situated along the margin of the seamount, in a younger tectonic depression (Greene et al., this volume). An alternative explanation would be that the environmental conditions in the pore space near the basalt/sediment contact were very peculiar; in fact, interparticle cementation in all the limestone caps investigated is restricted to the lowermost few meters of the shallowwater limestones. 
The second generation of calcite crystals is interpreted as an allochthonous cement. It also lacks all features of vadose diagenesis. On Suiko Seamount, there is a strong increase of second-generation cementation in the lowermost meter of calcarenite toward the basalt/limestone contact, which indicates a pronounced chemical gradient. Also, the second generation of calcite appears to have formed contemporaneously with the precipitation of phillipsite from pore solutions. The occurrence of phillipsite in these carbonates cements indicates an unusual pore-water chemistry with a relatively high $\mathrm{K} / \mathrm{Na}$ ratio, a high activity of $\mathrm{H}_{4} \mathrm{SiO}_{4}$ and a high $p \mathrm{H}$, which is related to the hydrolysis of the underlying basaltic material. Furthermore, alteration of plagioclase, particularly the replacement of calcium by sodium or potassium (Hart, 1970), is a likely source of calcium ions. Both the strong alkalinity of the solution, resulting from the hydrolysis of basalt, and the increase of the calcium concentration would tend to promote precipitation of calcium carbonate cements. Such a mechanism has been invoked by several authors to explain the submarine cementation of ultramafic and basaltic breccias (Bonatti et al., 1974; Bernoulli, Garrison, and McKenzie, 1978). Our oxygen isotope data are in agreement with such a low-temperature origin of both calcite and zeolite cements.

\section{Zeolite Cements}

Authigenic zeolites have been observed in some of the white and gray bryozoan-red algal carbonate sands at Site 433 (Samples 433A-16, CC; 433A-17, CC; 433A-18, CC; 433A-19, CC; and Core 433B-1), in most of the cemented calcarenites overlying basalt at the same site (Cores 433B-4 and 433C-1), and at Site 430 (Core 430A-4), and in the volcanic sandstones at Site 432 (Core 432A-1).

In the uncemented carbonate sands at Site 433, phillipsite occurs as euhedral crystals up to $50 \mu \mathrm{m}$ long, which, in most cases, are moderately to strongly etched. In Samples 433B-1-1, $75 \mathrm{~cm}$ and 433C-17, CC and 433C$18, \mathrm{CC}$, euhedral crystals of authigenic $\mathrm{K}$-feldspar are present. The K-feldspars show typical low-temperature (adularia) habit, and in SEM some are visible as overgrowths on coccoliths.

In the cemented calcarenites of Suiko Seamount, the zeolitic cement consists of remarkably euhedral phillipsite crystals. Most crystals show pseudo-orthorhombic symmetry and two-sided "domal" terminations (Plates 7 - 9; Mumpton and Ormsby, 1976). They often occur as cruciform (Plate 7, figure 7; Plate 8, figure 8, Plate 9, figure 6; Murray and Renard, 1891) or complex sector twins (Plate 9, figure 5). Cracking of the crystals along cleavage surfaces parallel to the axis of elongation is common (Plate 9, figures 3 - 6; cf. Mumpton and Ormsby, 1976), but no etching is present. Crystals range up to $50 \mu \mathrm{m}$ wide and $150 \mu \mathrm{m}$ long. The length of most, however, is on the order of 50 to $70 \mu \mathrm{m}$, and the width is 15 to $25 \mu \mathrm{m}$. All phillipsites are K-phillipsites; qualitative energy-dispersive microprobe analysis attached to a SEM (EDAX 707A) did not show the presence of $\mathrm{Ca}$ or $\mathrm{Na}$.

Although some clasts of basalt are present in the calcarenites, there is no textural evidence for zeolitic replacement of a volcanic precursor. Virtually all the phillipsite crystals grow from nucleation sites on calcitic grains or on early calcitic cements into open pore space, hindered only by competitive growth of calcitic cement (Plates 7 -9). Also, the zeolite crystals are very pure and lack inclusions of nontronite or other clays which are common in zeolites replacing volcanic material (e.g., Bonatti, 1963).

The growth of phillipsite in the cemented calcarenites commonly postdates solution of aragonitic shell material and precipitation of early fibrous calcite cement. Phillipsite typically occurs inside aragonite molds, which are lined by calcite-cemented micrite rims and within patches composed of neomorphic microspar and calcite cement filling larger, formerly aragonitic fossils (Plate 8 , figures $1-7$ and 9). It usually nucleates on early fibrous cement (Plate 7, figures 1-7; Plate 8, figures 1 7). In many instances, the growth of phillipsite can be shown to be contemporaneous with later "dog-tooth" calcite cements (Plate 9, figure 4), and with fast-growing syntaxial overgrowth on echinoderm fragments. Often the zeolite occurs as euhedral crystals within such syntaxial overgrowth poikilotopes (Plate 7, figures 8 and 9).

In the cemented calcarenites overlying basalt at Hole $430 \mathrm{~A}$, both phillipsite and clinoptilolite occur. As in the calcarenites of Site 433 , both zeolites occur as voidfilling cements, and there is no observable direct relationship to a volcanic precursor. Precipitation of zeolite cements postdates dissolution of aragonite and precipitation of early fibrous calcite cement. Similarly, phillipsite occurs as euhedral crystals with pseudo-orthorhombic symmetry and two-sided "domal" terminations (Figure 8, b and c); clinoptilolite occurs as euhedral, elongated, twinned pseudotetragonal crystals with domal terminations (Plate 10, figures 2 - 4). Clinoptilolite is also closely associated with an unidentified rodshaped mineral of unknown composition (Plate 10, figures 5 and 6).

In the volcanic sandstones overlying the basaltic rocks at Hole 432A, numerous fine-grained alteration products of the basaltic fragments and phyllosilicate (smectite) cements are present. These have not been investigated during this study. However, euhedral crystals of phillipsite occur also in these rocks as cements precipitated from pore solutions (Plate 10, figure 1). Matter and Gardner (1975) have reported the occurrence at Kōkō Seamount of clinoptilolite in the dark yellowish brown clayey silts of Core 1 , Site 308 , which are interpreted as volcanic ash. No zeolites were found in the cemented shallow-water limestones. We have detected only very small amounts of a zeolite. These are euhedral crystals, probably phillipsite, which occur together with calcite as a cement in neomorphically altered algal fragments (Matter and Gardner, 1975, Plate 1, figure 2; our Plate 8, figure 9). Also these zeolite crystals have been precipitated from pore solutions.

\section{Origin of Zeolite Cements}

Phillipsite is common in slowly accumulating, volcanogenic and clayey, deep-sea sediments. It typically occurs 
in brown deep-sea clays of the Pacific (Bonatti, 1963), where it is usually associated with smectites, palagonite, $\mathrm{Mn}-\mathrm{Fe}$ oxides, and altered mafic volcanic material. Formation begins at the sediment/water interface and continues over an extended period of time. Phillipsite is rarely found below 200 meters of overburden or in preTertiary sediments. Clinoptilolite, often associated with opal-CT, smectites, and attapulgite, is widespread in hemipelagic and pelagic marls and chalks, but also in deep-sea sediments rich in volcanic detritus (Cronan, 1974). No occurrence of zeolite cements in shallowwater carbonates has, to our knowledge, been previously described.

In a thorough review of all occurrences of phillipsite and clinoptilolite recovered by the Deep Sea Drilling Project, Kastner and Stonecipher (1978) have shown that phillipsite prevails in young (Miocene to Recent) sediments at shallow depth, predominantly in volcanogenic and clayey sediments, whereas clinoptilolite occurs mainly in older (Cretaceous to Miocene) and more deeply buried (100 to $700 \mathrm{~m}$ ) sediments of prevailing marly or calcareous composition. This could mean that phillipsite is replaced in time and buried by other silicates, mainly clinoptilolite. This transformation would be enhanced in a carbonate environment. Kastner and Stonecipher (1978) emphasize the occurrence of increasingly etched and dissolved phillipsite below the sediment surface, suggesting that phillipsite is metastable in the deep-sea environment, or that at least its stability field is very restricted. In contrast to these observations, we have noted etched crystals of phillipsite in the uncemented carbonate sands at Site 433, but the phillipsite crystals in the cemented calcarenites below do not show traces of dissolution, but are generally well preserved. At Site 430 , clinoptilolite and phillipsite coexist in the same sample, but there are no indications of replacement of phillipsite by clinoptilolite.

Volcanic material, in particular volcanic glass and palagonite, is the most commonly reported precursor of deep-sea zeolites (Bonatti 1963, Nayudu, 1964). In many cases, however, clinoptilolite and occasionally phillipsite occur in almost pure nannofossil oozes in which it is difficult to find direct evidence of volcanic debris except for the secondary presence of the zeolites (Bass, 1976, p. 619). Likewise, the unusual occurrence of phillipsite and clinoptilolite in the shallow-water limestones of the Emperor Seamounts does not appear to be directly related to an association with volcanic material, but is certainly related to the close proximity of the underlying basalt. Similar occurrences of phillipsite cements have been described in limestones cementing basaltic breccias (Bernoulli, Garrison, and McKenzie, 1978) and in foraminiferal sandstones overlying these rocks (Bernoulli, Garrison, and Mélières, 1978) in the Tyrrhenian Basin of the Mediterranean Sea.

The main factors controlling the growth of zeolites are chemistry of the precursors, chemistry of solutions, composition of the host sediment, and temperature (Kastner and Stonecipher, 1978). In the marine environment, basaltic glass is the most common phillipsite precursor. The proximity of the basalt basement to the carbonates in the Emperor Seamounts suggests alteration of basaltic glass as a source of cations, alumina, and silica. Because the zeolite crystals occur as porefilling chemical precipitates without an immediate volcanic precursor, they must have formed during interstitial dissolution-precipitation processes. It is impossible to distinguish whether the dissolved material originated directly from the hydrolysis of basaltic glass or through an intermediate step of alteration to palagonite and smectite, as suggested by Murray and Renard (1891), Bonatti $(1963,1965)$, and others. Some authors (e.g., Arrhenius, 1963) have suggested that clinoptilolite is not necessarily derived from a volcanic precursor but could form from silica derived from biogenic sources and other elements dissolved in sea water. However, in the absence of a biogenic source of silica in the shallowwater calcarenites, the basalts are also the most likely source for the formation of the clinoptilolite crystals.

The Emperor Seamount zeolites did not grow at the sediment/water interface, but after deposition of the sediment and formation of early diagenetic fibrous calcite cement. Textural evidence clearly indicates that the phillipsite and clinoptilolite cements were precipitated from pore solutions. They grew contemporaneously with the later "dog-tooth" and syntaxial overgrowth cements, but at a lower rate than the latter, as shown by the phillipsite overgrown by large poikilotopic calcite. It may be significant that in the fully cemented calcarenites immediately overlying the basalt, zeolites are rare (Samples 433C-1-1, 13-24 cm and 433B-4-1, $37 \mathrm{~cm}$ ), suggesting that the slowly growing zeolites could not efficiently compete with the fast-growing calcite.

A low-temperature origin of the zeolites is demonstrated by the oxygen-isotope composition of the associated calcite, some of which grew contemporaneously as a pore-filling cement. Void-filling phillipsite cements have also been described by Morgenstein (1967), Garrison et al. (1973), Bernoulli, Garrison, and McKenzie (1978), and Bernoulli, Garrison, and Mélières (1978). Likewise, in one of these cases oxygen-isotope data suggest a low-temperature origin (Bernoulli, Garrison, and McKenzie, 1978). Clinoptilolite has often been reported as a "replacement" in radiolarian tests (Benson, 1972), but textural evidence also suggests the precipitation of this zeolite cement from pore fluids (Plate 10; cf. Berger and von Rad, 1972; Boles, 1977).

Many authors (Nayudu, 1964; Garrison et al., 1973) have stressed the common occurrence of zeolites and "secondary carbonates". The alkaline environment favorable for the precipitation of late diagenetic calcite cements and of zeolites in a low-temperature regime may be directly related to the alteration of basaltic material, which leads to increased $p \mathrm{H}$ and calcium concentration of pore waters (Thompson, 1972; Bonatti et al., 1974). Both would tend to promote the precipitation of $\mathrm{CaCO}_{3}$, especially in the presence of preexisting carbonates. In fact, the passage upsection from fully cemented basalt-carbonate breccias at the sediment/basalt contact through cemented calcarenites into friable 
and uncemented carbonate sands suggests a chemical gradient created during slow, low-temperature alteration of the basalt.

\section{PALEOGEOGRAPHIC IMPLICATIONS}

Previous studies on the paleolatitudinal implications of shallow-water carbonate sediments deposited on seamounts in the Emperor Seamount chain have been based on the identification or interpretation of these deposits as representing true tropical coral reef buildups (Davies et al., 1972, and Greene et al., 1978). On the basis of such interpretations, paleolatitudes were derived which indicated that the Emperor Seamounts formed at the latitude of the island of Hawaii, now positioned over the hot spot that is the alleged source of the Hawaiian-Emperor linear island chain system.

It is the purpose of this section to point out that (1) the shallow-water carbonate deposits found on the Emperor Seamounts are not true tropical coral reefs but a bryzoan-rich, coral-poor carbonate facies typically found north and south of the tropical reef belt; (2) that such an interpretation of the latitude of formation of these carbonates is consistent with the measured paleolatitude of Suiko Seamount of $26.9^{\circ} \pm 3.5^{\circ} \mathrm{N}$ (Kono, this volume).

\section{Bryozoan-Versus Coral-Rich Sediments as Latitude Indicators}

For many years, the relative scarcity of bryozoans on coral reefs growing in the warm shallow waters of tropical seas has been remarked by geologists and paleontologists. Further, the abundance of bryozoans relative to corals has been noted in limestone formations laid down in high northern and southern latitudes. On the basis of a study of the literature, thin sections, and field observations (Figure 12), Schlanger and Knoishi $(1966,1975)$ developed a regional facies model (Figure 13) that explained the bipolar distribution of bryozoan-rich sediments in terms of sea water temperature and solar insolation values, both of which systematically decrease with increasing latitude. Chave (1967) also has noted the abundance of bryozoans in mid- and high-latitude carbonate deposits. Limestones and unconsolidated sediments from the "bryozoan-algae" facies are characterized by high (volumetric) percentages of bryozoans; corals are present but rare, and do not form major wave-resistant reefs. Many different growth forms of bryozoans may be present, ranging from encrusting types to delicate branching types. Red calcareous algae of both encrusting and digitate form are abundant. Molluscan debris is common and brachipods are locally abundant. Plio-Pleistocene limestones from the island of KikaiJimi, at $28^{\circ} \mathrm{N}$ latitude in the Ryukyu Islands (Schlanger and Konishi, 1966) may be taken as modern analogs of the shallow-water carbonates drilled and dredged in the Emperor-Seamount chain. Figure 14 shows a typical deposit of poorly sorted bryozoan gravel with whole and broken mollusk shells. In addition to the bryozoan fragments, encrusting bryozoans and algae coat many pieces of bioclastic debris. Locally, the encrusting algae and bryozoans build up on original fragments of shell to form algal nodules, as shown in Figure 15. These apparently form under conditions where strong currents sweep the sea floor.

Comparison of Shallow-Water Carbonates from the Emperor Seamounts with the "Bryozoan-Algal""Coral-Algal"' Facies Model

Kōko Seamount: Shallow-water carbonate sediments from dredge hauls on Kōkō Seamount $\left(35^{\circ} 30^{\prime} \mathrm{N}\right.$ latitude) have been described by Davies et al. (1972); and similar sediments from DSDP cores have been described by Matter and Gardner (1975) and Larson, Moberly, et al. (1975). The dredge hauls were described as reef limestones, but the DSDP cores contained Eocene bioclastic skeletal debris made up of benthic foraminifers, ostracodes, fragments of coral (largely alcyonarians), and bryozoans. As pointed out by Larson, Moberly, et al. (1975), the main difference between the Kōkō sediments and modern sediments of the Hawaiian sublittoral types is the high bryozoan content of the Kōkō material. The bryozoans at Kōkō have been interpreted as sublittoral deposits. Davies et al. (1972) note that lower Tertiary hermatypic corals from Kōkō were identified by J. W. Durham. On the basis of the foregoing description, we place these sediments in the facies model near the boundary between massive coral-algal reef complexes and reef complexes intermixed with bryozoan-algal biostromes, sands, and bioclastic debris. According to the facies model (Figure 13), this would place Kōkō Seamount during the Eocene at a paleolatitude corresponding to a modern $20^{\circ}$ to $22^{\circ} \mathrm{N}$. The stable-isotopic data (Figure 10) indicate that shallow-water carbonates from Kōkō re-equilibrated in waters warmer than those to which the limestones from Suiko, Ōjin, and Nintoku were exposed. The warmer diagenetic waters may also reflect warmer overlying surface waters at Kōkō.

Ojin Seamount: At Ojin Seamount $\left(37^{\circ} 59^{\prime} \mathrm{N}\right.$ latitude), core recovery was very poor, but sufficient material was recovered to prove that in the late Paleocene to middle Eocene, shallow-water skeletal carbonates accumulated. The abundance of algal nodules containing bryozoans indicates that these sediments are related to the "bryozoan-algal" facies, and are not true "coral-algal" deposits. At Ōjin, the cores showed that these carbonates accumulated over a subaerially weather basalt basement; water depth was therefore shallow. Perhaps the observed ooids, in conjuntion with the welldeveloped algal balls, indicate turbulent water conditions. Thus, these sediments could have accumulated on open-to-the-sea shallow banks. The paleolatitude of Ojin, accordng to the facies model, was probably $20^{\circ}+\mathrm{N}$ latitude.

Nintoku Seamount: Nintoku ( $41^{\circ} 20^{\prime} \mathrm{N}$ latitude) has a history of post-volcanic sedimentation virtually identical to that at Öjin. The upper Paleocene to lower Eocene skeletal debris, dominated by algal nodules, gastropods, bryozoans and echinoids, fish debris and worm tubes, places these sediments well within the "bryozoan-algal" facies, and probably reflects an open-to-the-sea shallow bank origin. The paleolatitude 


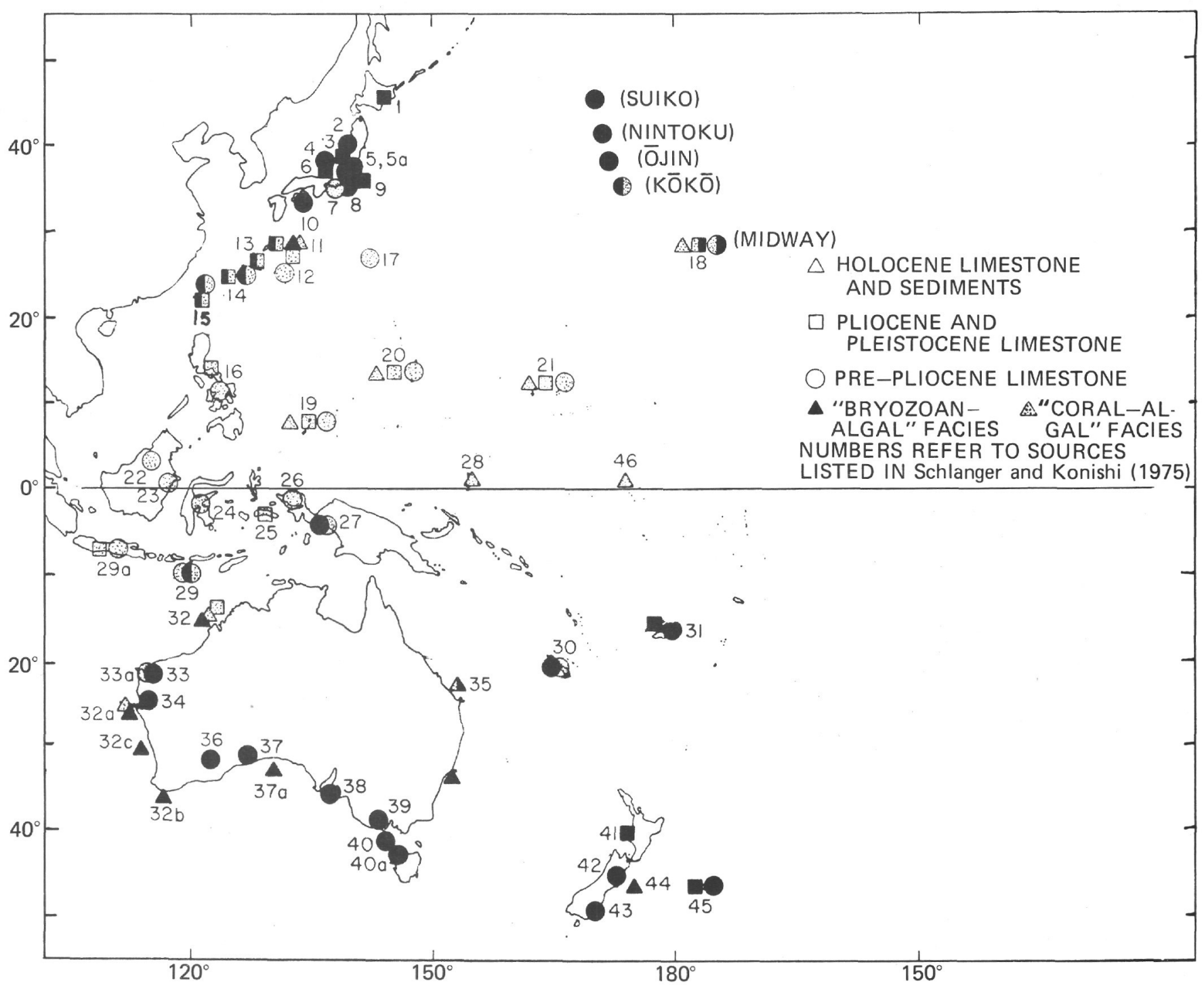

Figure 12. Map of western Pacific, showing the latitudinal distribution of the "Bryozoan-Algal" and the "Coral-Algal" facies. Modified from Schlanger and Konishi (1975). Note the position of the Emperor Seamounts.

of Nintoku may well have been about $22^{\circ} \mathrm{N}$. As for Kōkō Seamount, the isotopic indications that diagenetic waters were warmer at Nintoku and Ōjin seamounts than at Suiko Seamount (Figure 10) may also reflect equivalently warmer overlying surface waters.

Suiko Seamount: At Suiko Seamount $\left(44^{\circ} 47^{\prime} \mathrm{N}\right.$ latitude), shallow-water skeletal debris, dominated by algal balls that contain encrusting bryozoans, and bioclastic sands made up of sorted and rounded red algal, bryozoan, echinoid, and molluscan fragments, accumulated during middle to late Paleocene time. These were laid down directly over a volcanic basement the paleolatitude of which was determined as $26.9^{\circ} \pm 3.5^{\circ} \mathrm{N}$ by magnetic measurements (Kono, this volume). Thus, at Suiko the paleolatitude as measured fits very well with the paleolatitude inferred from the sediments which are typical of the "bryozoan-algal" facies. See Plate 1 for petrographic characteristics of the Paleocene Suiko limestones and a comparison of them with Eocene limestones from the Mijara Formation on Ishigaki-Jima, Ryukyu Islands.

\section{CONCLUSIONS}

Deep sea drilling on seamounts in the Emperor Seamount chain revealed that the basalt edifices are overlain by shallow-water carbonate sediments. The carbonate sediments are interpeted as representative of a highenergy environment with water depths of about 20 meters. Moving southward along the chain, a facies gradient in the sediments is manifested by a decrease in the predominance of bryozoans and coralline algae and the introduction of ooids on Ōjin and ooids and some corals on Kōkō. We conclude that this gradient was not primarily depth-controlled but regulated by surface water temperatures. An increase in surface water temperatures could be achieved by placing the active volcanoes in paleolatitudes progressively more southerly with time. Alternatively, a northward shift of the 

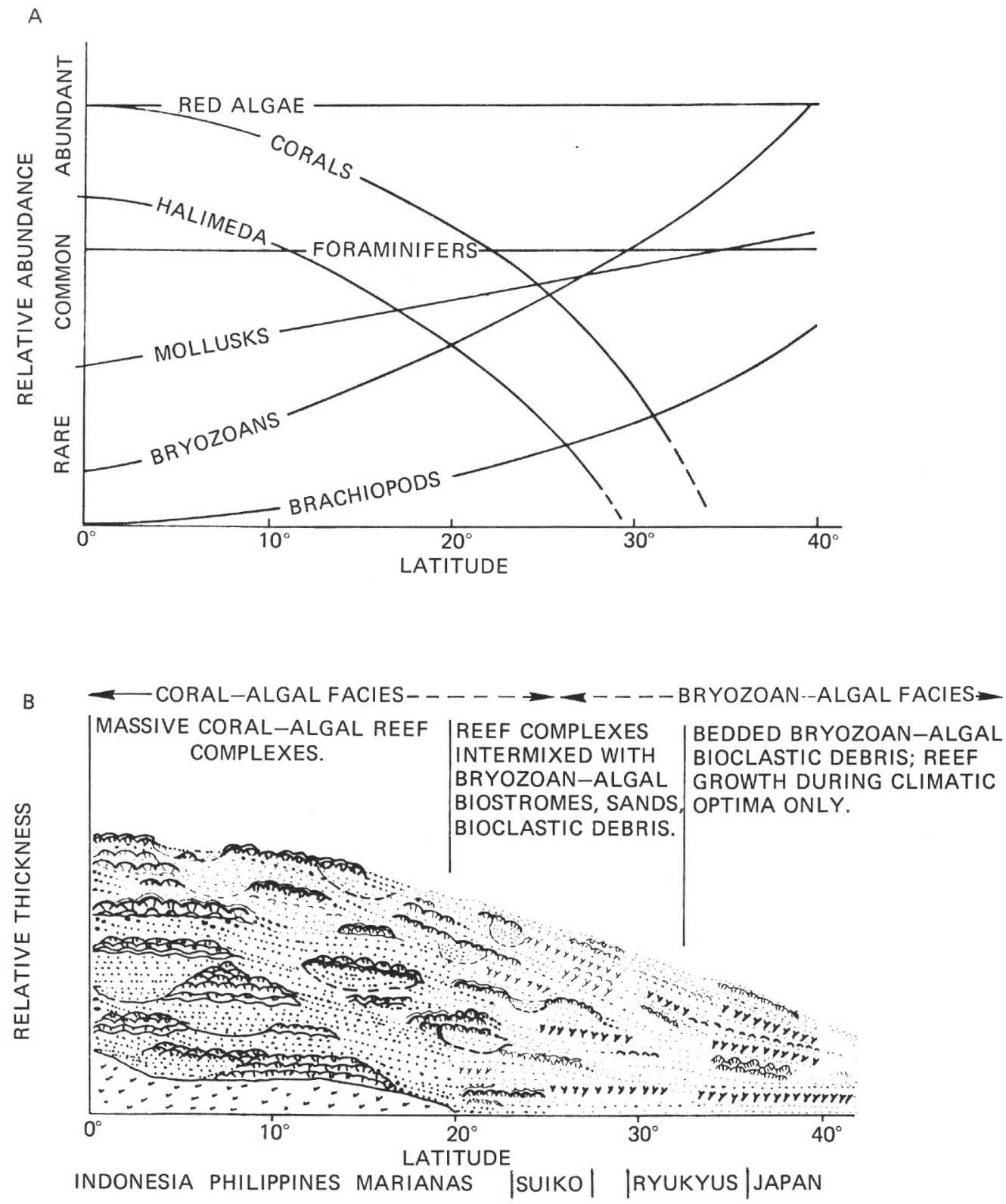

Figure 13. (A) Relative abundance of major limestone-forming organisms, according to latitude in the western Pacific. (B) Facies model showing the latitude-dependent distribution and characteristics of the "Coral-Algal" and "Bryozoan-Algal" facies in the western Pacific. The paleolatitude of Suiko is indicated. Modified from Schlanger and Konishi (1975).

isotherms, as indicated by the stable-isotope date from this study and from Savin et al. (1975), could produce the same facies gradient by raising the surface water temperature at a specific latitude, such as the paleolatitude of seamount formation.

The diagenesis of the shallow-water carbonate sediments proceeded in two steps. Early-stage diagenesis began with the dissolution of aragonite and precipitation of calcite rim cement, probably in the phreatic environment under the influence of meteoric waters. The diagenetic stage V of Land et al. (1967) was reached. This interpretation from petrographic evidence applies only to the cemented limestone caps on the seamounts.
In the case of the unconsolidated sediments on Suiko Seamount, the transformation of high-magnesium calcite and aragonite to low-magnesium calcite was also complete, but with only minor cementation by micrite and intraparticle sparite. The stable isotopic composition of the sediments is interpreted as evidence that the bulk of the diagenetic re-equilibration must have happened in cooler intermediate waters underlying the surface waters. Although meteoric water greatly accelerates the mineral transformation, it is thought that the process of dissolving aragonite and converting highmagnesium calcite to low-magnesium calcite may also occur slowly in sea water over very long periods (Berner, 


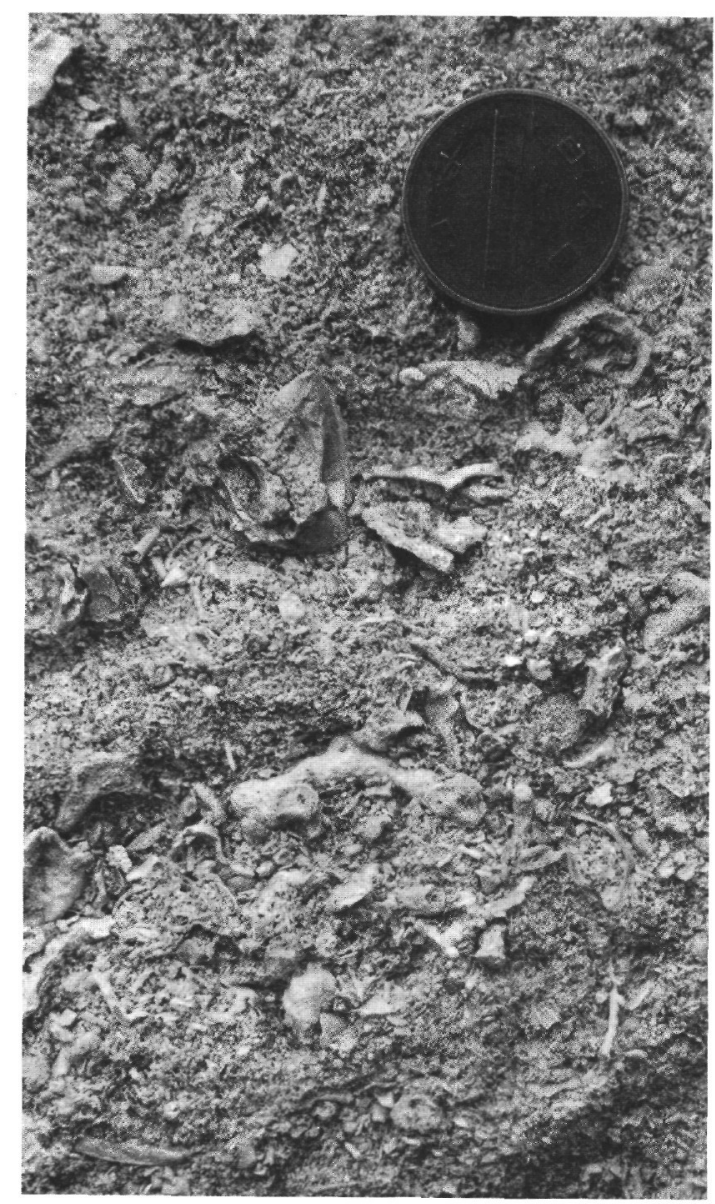

Figure 14. Closeup view (coin is approximately $20 \mathrm{~mm}$ in diameter) of crudely bedded, poorly sorted limestone from the "Bryozoan-Algal" facies of PlioPleistocene age from Kikai-Jima, Ryukyu Islands. The sand fraction is made up of red algal, bryozoan, foraminiferal, and molluscan debris. Larger pieces of bryozoans and mollusks are encrusted by red algae and bryozoans.

1971). If the isotopic temperatures of the shallow-water sediments correspond to the time-equivalent foraminiferal temperatures (Figure 11), as herein interpreted, the early-stage diagenesis must have been completed within a 5 to 10 million year time span. To set an isotopic composition which reflects the positions of the paleoisotherms requires a fairly rapid subsidence of the seamount into cooler intermediate waters. Because the bioassemblage in the shallow-water sediments does not represent a coral reef population, there could have been no reef buildup to compensate for the subsidence, as on islands in more tropical regions of the Pacific. These two factors, the rapid subsidence and the deposition of limestones of the "bryozoan-algal" facies, contributed to the relative scarcity of shallow-water sediments capping the Emperor Seamounts.

The second, late-stage diagenesis involves the precipitation of "dog-tooth" calcite simultaneously with zeolites in the available pore spaces of the carbonate sedi- ments. Both precipitates originate from solutions which are migrating upward from the underlying basalts. Lowtemperature alteration of the basalts provides the high alkalinity, calcium ions, and relatively high $\mathrm{K}: \mathrm{Na}$ ratios needed for precipitation of zeolites and calcite.

Determination of the paleolatitude of $26.9^{\circ} \pm 3.5^{\circ} \mathrm{N}$ (Kono, this volume) for the volcanic edifice underlying Suiko Seamount does not fit well with the paleolatitude predicted by the hot-spot hypothesis of Wilson (1963) and Morgan (1972). According to this hypothesis, Suiko formed at the site of the present hot spot, located under the island of Hawaii at $19.5^{\circ} \mathrm{N}$ latitude. Greene et al. (1978) used the presumed coral reef caps on edifices in the Emperor Seamount chain as arguments for the origin of Suiko Seamount at the Hawaiian hot spot. As shown in the foregoing, our analysis of the composition of these "reefs" indicates that the shallow-water carbonates on Suiko could have formed at $26.9^{\circ} \pm 3.5^{\circ} \mathrm{N}$, since they are typical of the "bryozoan-algal" facies of Schlanger and Konishi $(1966,1975)$. We suggest that the paleomagnetic data and the facies analysis argue against formation of Suiko Seamount at the latitude of the present Hawaiian hot spot. The facies and warmer isotopic temperatures of Kōkō Seamount indicate, however, that Kōkō may well have formed at a paleolatitude closer to that of the Hawaiian hot spot or in warmer waters as a result of the northward shift in isotherms.

As regards Suiko, at least, we believe that there is no compelling evidence for the "backtracking" of Suiko to $19-20^{\circ} \mathrm{N}$ latitude as proposed by Greene et al. (1978). If our interpretation of the facies and the isotope date is correct, and if the paleomagnetic determination of the paleolatitude of Suiko is correct, then the WilsonMorgan hot spot hypothesis must be modified to allow the formation of Suiko at some distance from the present location of the Hawaiian hot spot. The $26.9^{\circ} \pm 3.5^{\circ} \mathrm{N}$ paleolatitude determination, compared with the $19.5^{\circ} \mathrm{N}$ location of the Hawaiian hot spot today, calls for a difference, between the site of formation of Suiko and the present hotspot, of from at least $4^{\circ}$ to as much as $11^{\circ}$. According to data presented by Jackson (1976), the Hawaiian hot spot can be interpreted as having an effective radius at the earth's surface of approximately $150 \mathrm{~km}$. Clearly, the $26.9^{\circ} \pm 3.5^{\circ} \mathrm{N}$ paleolatitude determination places the initial position of Suiko well outside the effective radius of the present Hawaiian hot spot. Our interpretations of the facies and isotopic data from this study of the shallow-water carbonate sediment are not inconsistent with the paleomagnetic data (Kono, this volume). We conclude, therefore, that the Hawaiian hot spot must not have always been fixed with respect to the earth's geomagnetic field and/or the earth's rotational axis.

\section{ACKNOWLEDGEMENTS}

This paper is Hawaii Institute of Geophysics contribution no. 972. Financial support for two of us (J.M. and D.B.) came from the Swiss National Science Foundation (Grants 2.125-0.74, 2.420-0.75, and 2.777-0.77). R. Guggenheim provided facilities at the REM-Laboratory at the Geological Institute of $\mathrm{Ba}$ sel University; Mrs. L. Luginbühl operated the microscope 


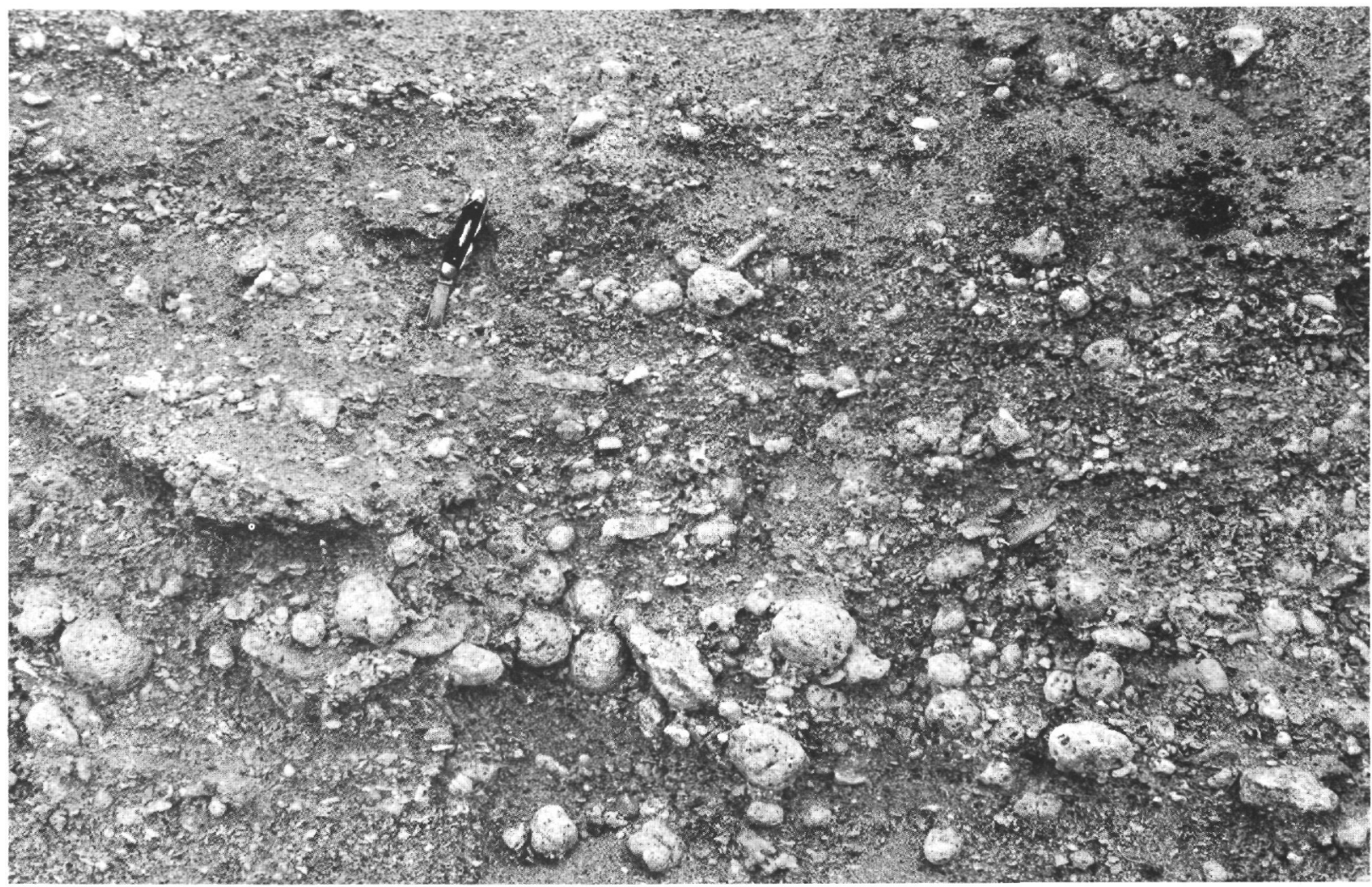

Figure 15. View of outcrop of typical algal nodule limestone from the "Bryozoan-Algal" facies of PlioPleistocene age on Kikai-Jima, Ryukyu Islands. This shows typical crude bedding, slight imbrication indicative of current motions (from left to right), and the high content of encrusting red algae in the form of subspherical balls. The nuclei of these are commonly fragments of bryozoans or mollusks. Encrusting bryozoans make up a significant portion of each algal nodule.

and prepared the photomicrographs. We are grateful to Albert Matter for lending us thin sections and samples from Kōkō Seamount, and for helpful discussions and comments on a draft of this manuscript. David Clague kindly provided the limestone samples from Kammu Seamount. We thank Stefan Graeser for some of the X-ray identification of zeolites. We also acknowledge Ken Hsü for critical discussions and Nicholas Shackleton for the suggestion of an oxygen-18 paleolatitude study.

\section{REFERENCES}

Adey, W. H., and Macintyre, I. G., 1973. Crustose coralline algae: a reevaluation in the geological sciences, Geol. Soc. Am. Bull., v. 84, pp. 883-904.

Arrhenius, G., 1963. Pelagic sediments. In Hill, M. N. (Ed.), The Sea: New York (Wiley Interscience), v. 3, pp. 655-727.

Bass, M. N., 1976. Secondary minerals in oceanic basalts, with special reference to Leg 34, Deep Sea Drilling Project. In Yeats, R. S., Hart, S. R., et al., Initial Reports of the Deep Sea Drilling Project, v. 34: Washington (U.S. Government Printing Office), pp. 393-432.

Bathurst, R. G. C., 1964. The replacement of aragonite by calcite in the molluscan shell wall. In Imbrie, J. and Newell, N. D. (Ed.), Approaches to Paleoecology: New York (Wiley), pp. 357-376.

1966. Boring algae, micrite envelopes and lithifica-

tion of molluscan biosparites, Geol. J., v. 5, pp. 15-32.
1971. Carbonate Sediments and Their Diagenesis Amsterdam (Elsevier).

Benson, R. N., 1972. Radiolaria, Leg 12, Deep Sea Drilling Project. In Laughton, A. S., Berggren, W. A., et al., Initial Reports of the Deep Sea Drilling Project, v. 12: Washington (U.S. Government Printing Office), pp. 1085-1113.

Berger, W. H. and von Rad, U., 1972. Cretaceous and Cenozoic sediments from the Atlantic Ocean. In Hayes, D. E., Pimm, A. C. et al., Initial Reports of the Deep Sea Drilling Project, v. 14: Washington (U.S. Government Printing Office), pp. 787-954.

Berner, R. A., 1971. Principles of Chemical Sedimentology: New York (McGraw-Hill Book Co.).

Bernoulli, D., Garrison, R. E., and Mélières, F., 1978. Phillipsite cementation in a foraminiferal sandstone at Hole 373A and "the case of the violated foram". In Hsü, K., Montadert, L., et al., Initial Reports of the Deep Sea Drilling Project, v. 42, part 1: Washington (U.S. Government Printing Office), pp. 478-482.

Bernoulli, D., Garrison, R. E., and McKenzie, J., 1978. Petrology, isotope geochemistry, and origin of dolomite and limestone associated with basaltic breccia, Hole 373A, Tyrrhenian Basin. In Hsü, K., Montadert, L. et al., Initial Reports of the Deep Sea Drilling Project, v. 42, part 1: Washington (U.S. Government Printing Office), pp. 541558

Boles, J. R., 1977. Zeolites in deep-sea sediments. In Mumpton, F. A. (Ed.), Mineralogy and Geology of Natural Zeo- 
lites: Min. Soc. America, Short Course Notes, v. 4, pp. 137-161.

Bonatti, E., 1963. Zeolites in Pacific pelagic sediments, Trans. N.Y. Acad. Sci., v. 25, pp. 938-948.

1965. Palagonite, hyaloclastites and alteration of volcanic glass in the ocean, Bull. Volcanol., v. 28 , pp. 257-269.

Bonatti, E., Emiliani, C., Ferrara, G., Honnorez, J., and Rydell, H., 1974. Ultramafic-carbonate breccias from the equatorial Mid-Atlantic Ridge, Mar. Geol., v. 16, pp. 83102.

Bosellini, A., and Ginsburg, R. N., 1971. Form and internal structure of recent algal nodules (rhodolites) from Bermuda, J. Geol., v. 79, pp. 669-682.

Chase, T. E., Menard, H. W., and Mammerickx, J., 1971. Topography of the North Pacific. Geologic Data Center, Scripps Institution of Oceanography and Institute of Marine Sciences.

Chave, K. E., 1967. Recent carbonate sediments - an unconvential view, J. Geol. Education, v. 15, pp. 200-204.

Cheetham, A. H., 1975. Preliminary report on early Eocene Cheilostome Bryozoans from Site 308-Leg 32, Deep Sea Drilling Project. In Larson, R. L., Moberly, R., et al., Initial Reports of the Deep Sea Drilling Project, v. 32: Washington (U.S. Government Printing Office), pp. 835-851.

Clague, D. A., and Jarrard, R. D., 1973. Tertiary Pacific plate motion deduced from the Hawaiian-Emperor chain, Geol. Soc. Am. Bull., v. 84, pp. 1135-1154.

Craig, H., 1957. Isotopic standards for carbon and oxygen and correction factor for mass-spectrometric analysis of carbon dioxide, Geochim. Cosmochim. Acta, v. 12, pp. 133-149.

Cronan, D. S., 1974. Authigenic minerals in deep-sea sediments. In Goldberg, E. D. (Ed.), The Sea: New York (Interscience), v. 5, pp. 491-525.

Dalrymple, G. B., and Clague, D. A., 1976. Age of the Hawaiian-Emperor bend, Earth Planet. Sci. Lett., v. 31, pp. 313329.

Darwin, C. R., 1842. The Structure and Distribution of Coral Reefs: London (Smith, Elder \& Co.).

Davies, T. A., Wilde, P., and Clague, D. A., 1972. Kōkō seamount: a major guyot at the southern end of the Emperor seamounts, Mar. Geol., v. 13, pp. 311-321.

Dunham, R. J., 1971. Meniscus cement. In Bricker, O. P. (Ed.), Carbonate Cements: Baltimore and London (The Johns Hopkins Press), pp. 297-300.

Evamy, B. D., and Shearman, D. J., 1965. The development of overgrowths from echinoderm fragments, Sedimentology, v. 5, pp. 211-233.

1969. Early stages in development of overgrowths on echinoderm fragments in limestones, Sedimentology, v. 12, pp. 317-322.

Ferrer, J., 1975. Neritic early Eocene smaller foraminifera from the Kōkō Seamount (Emperor Seamounts, central northern Pacific). In Larson, R. L., Moberly, R., et al., Initial Reports of the Deep Sea Drilling Project, v. 32: Washington (U.S. Government Printing Office), pp. 803823.

Garrison, R. E., Hein, J. R., and Anderson, T. F., 1973. Lithified carbonate sediment and zeolitic tuff in basalts, MidAtlantic Ridge, Sedimentology, v. 20, pp. 399-410.

Glover, E. D., and Pray, L. C., 1971. High-magnesium calcite and aragonite cementation within modern subtidal carbonate sediment grains. In Bricker, O. P. (Ed.), Carbonate Cements: Baltimore and London (The Johns Hopkins Press), pp. 80-87.
Greene, H. G., Dalrymple, G. B., and Clague, D. A., 1978. Evidence for northward movement of the Emperor Seamounts, Geology, v. 6, pp. 70-74.

Hamilton, E. L., 1956. Sunken Islands of the Mid-Pacific Mountains. Mem. Geol. Soc. Am. 64.

Hart, R., 1970. Chemical exchange between sea water and deep ocean basalts, Earth Planet. Sci. Lett., v. 9, pp. 269-279.

Hesse, R., 1973. Diagenesis of a seamount oolite from the West Pacific, Leg 20, Deep Sea Drilling Project. In Heezen, B. C., MacGregor, I. D., et al., Initial Reports of the Deep Sea Drilling Project, v. 20: Washington (U.S. Government Printing Office), pp. 363-387.

Jackson, E. D., 1976. Linear volcanic chains on the Pacific plate. In Sutton, G. H., Manghnani, M. H., and Moberly, R. (Ed.), The Geophysics of the Pacific Ocean Basin and its Margin: Am. Geophys. Union Mon. 19, pp. 319-335.

James, N. P., Ginsburg, R. N., Marszaleck, D. S., and Choquette, P. W., 1976. Facies and fabric specificity of early subsea cements in shallow Belize (British Honduras) reefs, J. Sediment. Petrol., v. 46, pp. 523-544.

Kastner, M., and Stonecipher, S.A., 1978. Zeolites in pelagic sediments of the Atlantic, Pacific, and Indian oceans. In Sand, L. B., and Mumpton, F. A. (Ed.), Natural Zeolites: New York (Pergamon Press), pp. 199-220.

Land, L. S., 1967. Diagenesis of skeletal carbonates, J. Sediment. Petrol., v. 37, pp. 914-930.

Land, L. S., Mackenzie, F. T., and Gould, S. J., 1967. Pleistocene history of Bermuda, Geol. Soc. Am. Bull., v. 78, pp. 993-1006.

Larson, R. L., Moberly, R., et al., 1975. Initial Reports of the Deep Sea Drilling Project, v. 32: Washington (U.S. Government Printing Office), p. 220.

Matter, A., and Gardner, J. V., 1975. Carbonate diagenesis at Site 308 Kōkō Guyot. In Larson, R. L., Moberly, R., et al., Initial Reports of the Deep Sea Drilling Project, v. 32: Washington (U.S. Government Printing Office), pp. 521535.

McCrea, J. M., 1950. The isotopic chemistry of carbonates and a paleotemperature scale, J. Chem. Phys., v. 18, pp. 849-857.

Milliman, J. D., 1974. Marine Carbonates. Recent Sedimentary Carbonates, Part I. Berlin (Springer-Verlag).

Moberly, R., and Keene, J. B., 1975. Origin and diagenesis of volcanic-rich sediments from North Pacific seamounts, DSDP Leg 32. In Larson, R. L., Moberly, R., et al., Initial Reports of the Deep Sea Drilling Project, v. 32: Washington (U.S. Government Printing Office), pp. 537-546.

Morgan, W. J., 1972. Deep mantle convection plumes and plate motions, Am. Assoc. Pet. Geol. Bull., v. 56, pp. 203-213.

Morgenstein, M., 1967. Authigenic cementation of scoriaceous deep-sea sediments west of the Society Ridge, South Pacific, Sedimentology, v. 9, pp. 105-118.

Mumpton, F. A., and Ormsby, W. C., 1976. Morphology of zeolites in sedimentary rocks by scanning electron microscopy, Clays and Clay Min., v. 24, pp. 1-23.

Mumpton, F. A., and Ormsby, W. C., 1978. Morphology of zeolites in sedimentary rocks by scanning electron microscopy. In Sand, L. B., and Mumpton, F. A. (Ed.), Natural Zeolites: New York (Pergamon Press), pp. 113-132.

Murray, J., and Renard, A. F., 1891. Report on deep-sea deposits. In Report on the Scientific Results of the Voyage of the H.M.S. Challenger During the Years 1873-76: London (Eyre \& Spottiswoode). 
Nayudu, Y. R., 1964. Palagonite tuffs (hyaloclastites) and the products of post-eruptive processes, Bull. Volcanol., v. 27, pp. 391-410.

Purser, B. H., 1969. Syn-sedimentary marine lithification of Middle Jurassic limestones in the Paris Basin, Sedimentology, v. 12, pp. 205-230.

Rex, R. W., 1967. Authigenic silicates formed from basaltic glass by more than 60 million years' contact with sea water, Sylvania Guyot, Marshall Islands, Clays and Clay Minerals, Proc. Nat. Conf., v. 15, pp. 11-17.

Savin, S. M., 1977. The history of the earth's surface temperature during the past 100 million years, Ann. Rev. Earth Planet. Sci., v. 5, pp. 319-355.

Savin, S. M., Douglas, R. G., and Stehli, F. G., 1975. Tertiary marine paleotemperatures, Geol. Soc. Am. Bull., v. 86, pp. 1499-1510.

Schlanger, S. O., 1963. Subsurface geology of Eniwetok Atoll. U.S. Geol. Surv. Prof. Paper 260-BB, pp. 991-1066.

Schlanger, S. O., and Konishi, K., 1966. Contrasting bryozoan content of Plio-Pleistocene to present day carbonates from Guam, Mariana Islands and Kikai-Jima, Ryukyu Islands, and its regional implications, Proc. XI Pac. Science Congress, Tokyo, Japan, Abstract No. 35.

1975. The geographic boundary between the coral-algal and the bryozoan-algal limestone facies: a paleolatitude indicator, Theme 1, Indicateurs Sédimentologiques, IX ${ }^{\text {me }}$ Congrès Int. de Sedim., Nice, France, pp. $187-190$.

Schroeder, J. H., 1972. Fabrics and sequences of submarine carbonate cements in Holocene Bermuda cup reefs, Geol. Rundschau, v. 61, pp. 708-730.

1973. Submarine and vadose cements in Pleistocene Bermuda reef rock, Sediment. Geol., v. 10, pp. 179-204.
Shackleton, N. J., 1973. Attainment of isotopic equilibrium between ocean water and the benthonic foraminifera genus Uvigerina: isotopic changes in the ocean during the last glacial, Colloques Internationaux du C.N.R.S. No. 219, pp. 203-209.

Shackleton, N. J., and Kennett, J. P., 1975. Paleotemperature history of the Cenozoic and the initiation of Antarctic glaciation: oxygen and carbon isotope analyses in DSDP Sites 277, 279 and 281. In Kennett, J. P., Houtz, R. E., et al., Initial Reports of the Deep Sea Drilling Project, v. 29: Washington (U.S. Government Printing Office), pp. 743755.

Sverdrup, H. U., Johnson, M. W., and Fleming, R. H., 1942. The Oceans: Their Physics, Chemistry and General Biology. New York (Prentice-Hall, Inc.).

Thompson, G., 1972. A geochemical study of some lithified carbonate sediments from the deep-sea, Geochim. Cosmochim. Acta, v. 36, pp. 1237-1253.

Wilson, J. T., 1963. A possible origin of the Hawaiian Islands, Can. J. Physics, v. 41, pp. 863-870.

Winland, H. D., 1971. Nonskeletal deposition of high-Mg calcite in the marine environment and its role in the retention of textures. In Carbonate Cements. O. P. Bricker (Ed.). Baltimore and London (The Johns Hopkins Press), pp. 278-284.

Winterer, E. L., Ewing, J. I., et al., 1973. Initial Reports of the Deep Sea Drilling Project, v. 17: Washington (U.S. Government Printing Office).

Winterer, E. L., 1977. Carbonate sediments on the flanks of seamount chains. In Andersen, N. R., and Malahoff, A., (Ed.), The Fate of Fossil Fuel $\mathrm{CO}_{2}$ in the Oceans: New York (Plenum Press-Marine Science), v.6, pp. 693-715.

\section{PLATE 1 \\ Comparative Petrography of Limestones from Suiko Seamount and Ishigaki-Jima, Ryukyu Islands}

Figure 1 Well-sorted, washed biosparite, containing mainly coralline algae, echinoderm fragments, and bryozoans. Middle to upper Paleocene, Suiko Seamount. Sample 433B-4-1, 22-24 cm.

Figure 2 Washed biosparite to biosparrudite with red algae, bryozoans, echinoderm and mollusk debris. Middle to upper Paleocene, Suiko Seamount. Sample 433-1-1, 22-24 cm.

Figure 3. Washed biosparite to biosparrudite with coralline algae, bryozoans, echinoids, mollusks, and fish remains. Middle to upper Paleocene, Suiko Seamount. Sample 433C-1-1, 11-13 cm.

Figure 4 Rhodolite, masses of encrusting coralline algae, and bryozoans dominate. Middle to upper Paleocene, Suiko Seamount. Sample 433A-12-3, 0-3 $\mathrm{cm}$.

Figures 5, 6 Calcirudites from the Miyara Formation on Ishigaki-Jima, Ryukyu Islands, Eocene. Crusts and fragments of calcareous red algae and bryozoans dominate. Ishigaki-Jima lies at $24^{\circ} 30^{\prime} \mathrm{N}$ latitude, the approximate paleolatitude of Suiko Seamount. Thin sections: plane light: 
PLATE 1
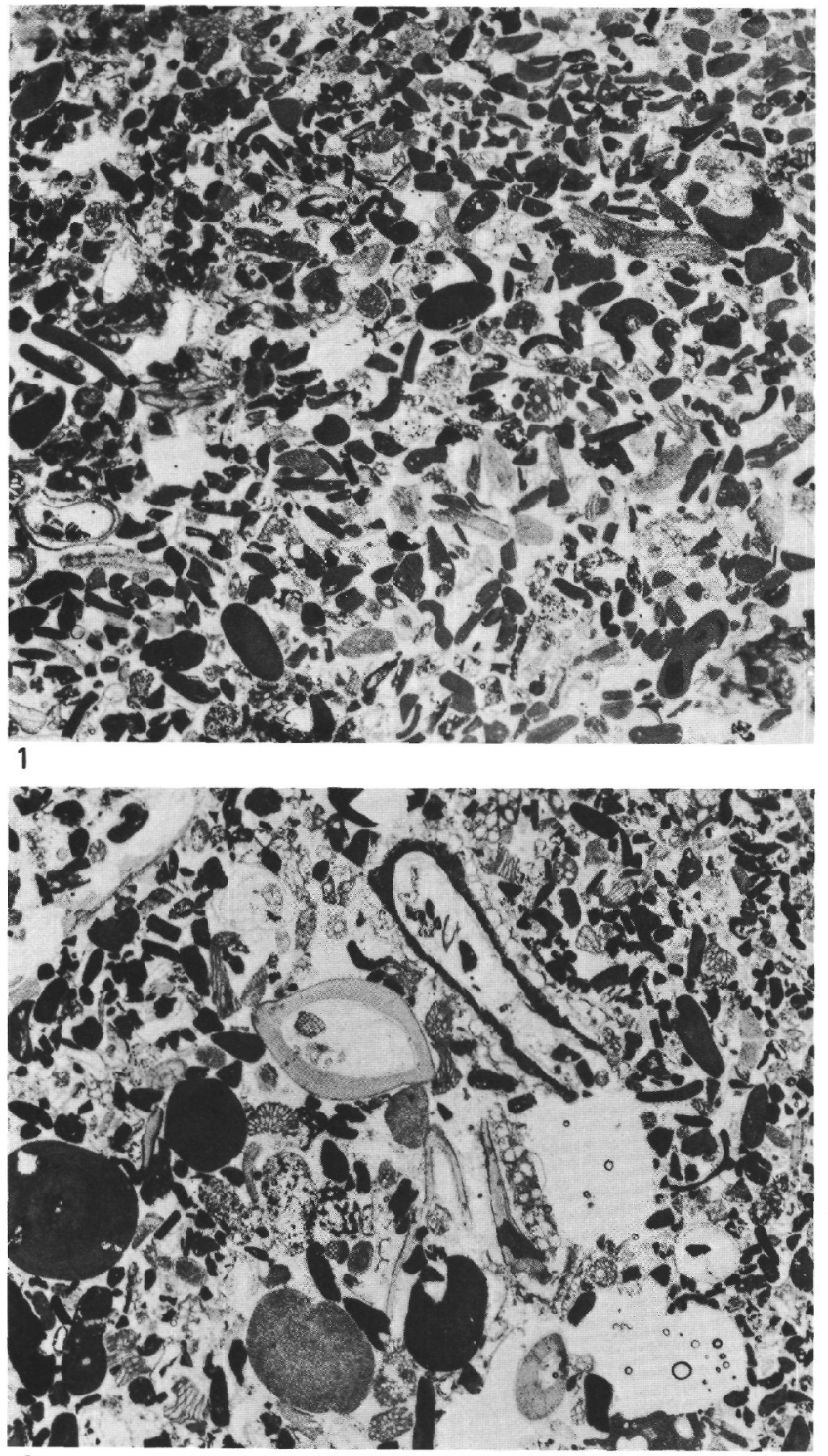

3

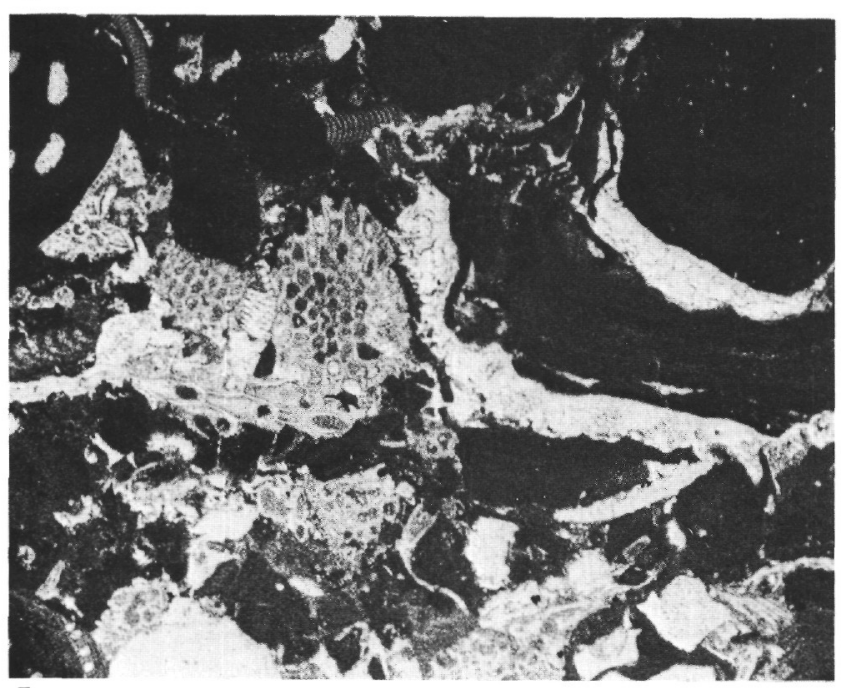

5
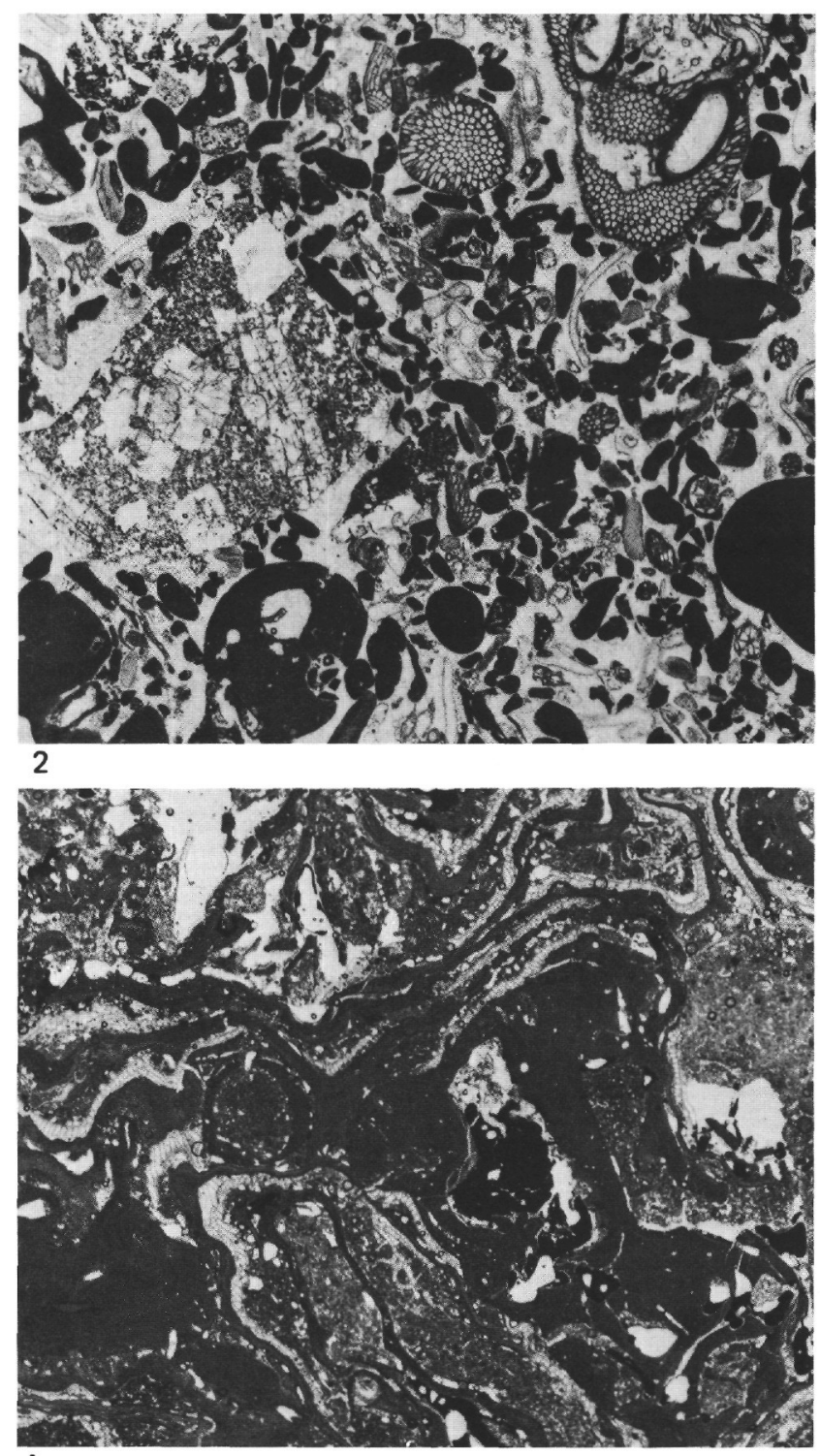

4

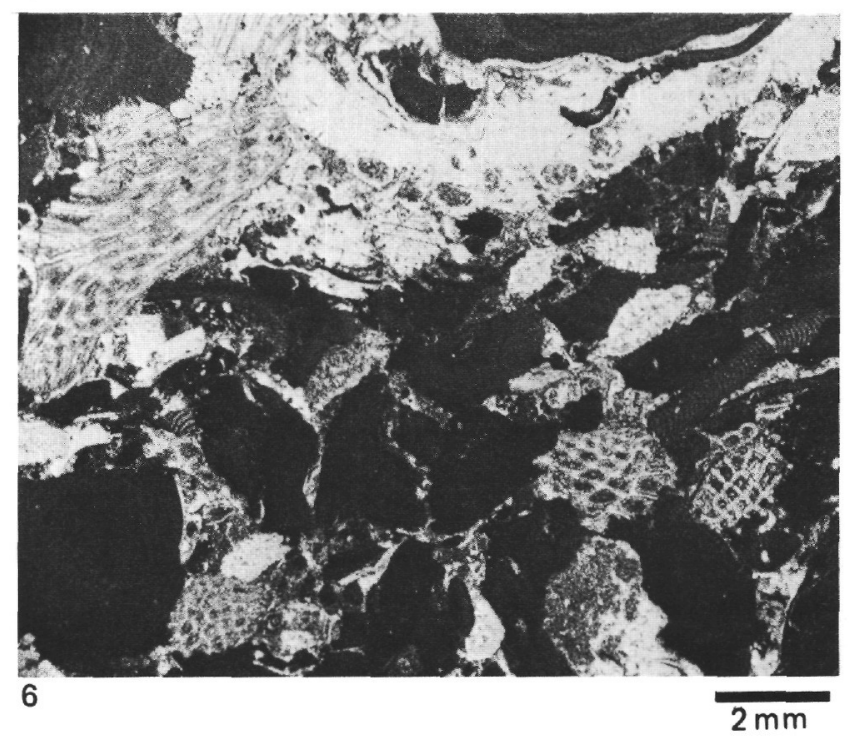


PLATE 2

Micrite Rims and Cementation in Shallow-Water Limestones, Middle to Upper Paleocene, Suiko Seamount, Site 433

Figures 1, 2 Formerly aragonitic fossils, such as gastropods (figure 1, right), were surrounded by a micrite rim which was not destroyed during subsequent dissolution of the skeletal aragonite. The micrite rims served as a foundation for growth of early calcitic palisade rim and later "dog-tooth" calcite and phillipsite (figure 2) cementing molds and interparticle pore space. Sample 433C-1-1, 11-13 cm. Thin section: plane light.

Figure 3 Shallow-water particles, mainly coralline algae and micrite rims, and rare volcanic particles are fully cemented by palisade rim, syntaxial overgrowth on echinoderms and blocky calcite. Former aragonitic gastropods are outlined by a micrite rim which was not destroyed during the dissolution of the skeletal aragonite. Sample 433C-1-1, 24 $\mathrm{cm}$. Thin section: plane light.

Figure 4 Stereoscan electron micrograph of micrite rim (upper right) which served as a substrate for early palisade rim and later "dog-tooth" cement. Sample 433B-4-1, $25 \mathrm{~cm}$.

Figures 5, 6 Micrite rim of former aragonitic particle which, after dissolution of skeletal aragonite, served as a foundation for the growth of early fibrous palisade rim cement. Note increase of crystal size toward center of the pore and later dog-tooth calcite. Sample 433B-4-1, $25 \mathrm{~cm}$. Stereoscan electron micrographs. 
PLATE 2

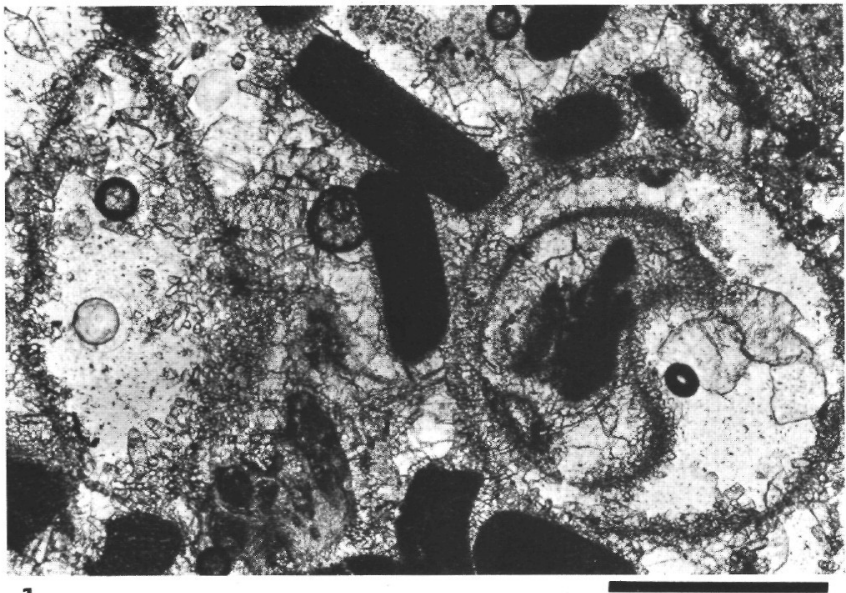

$0.5 \mathrm{~mm}$

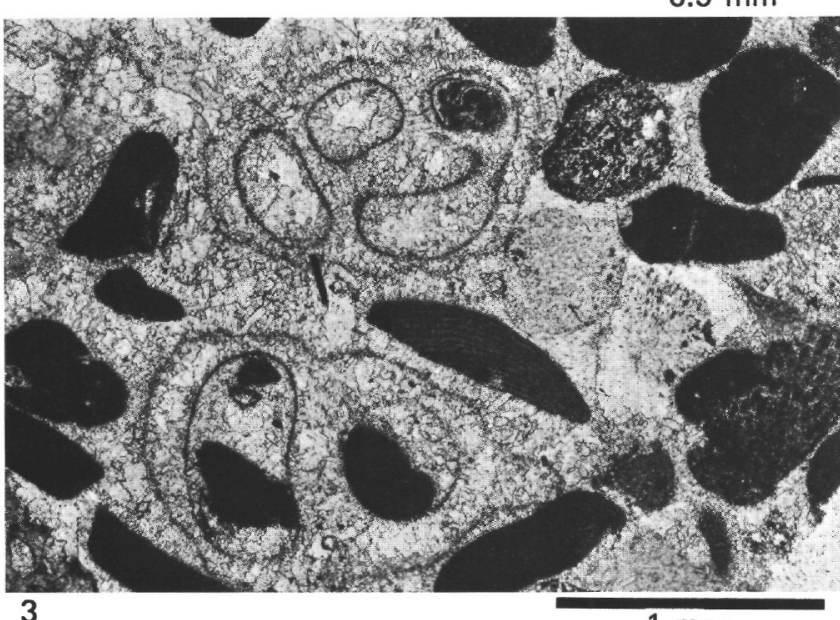

3

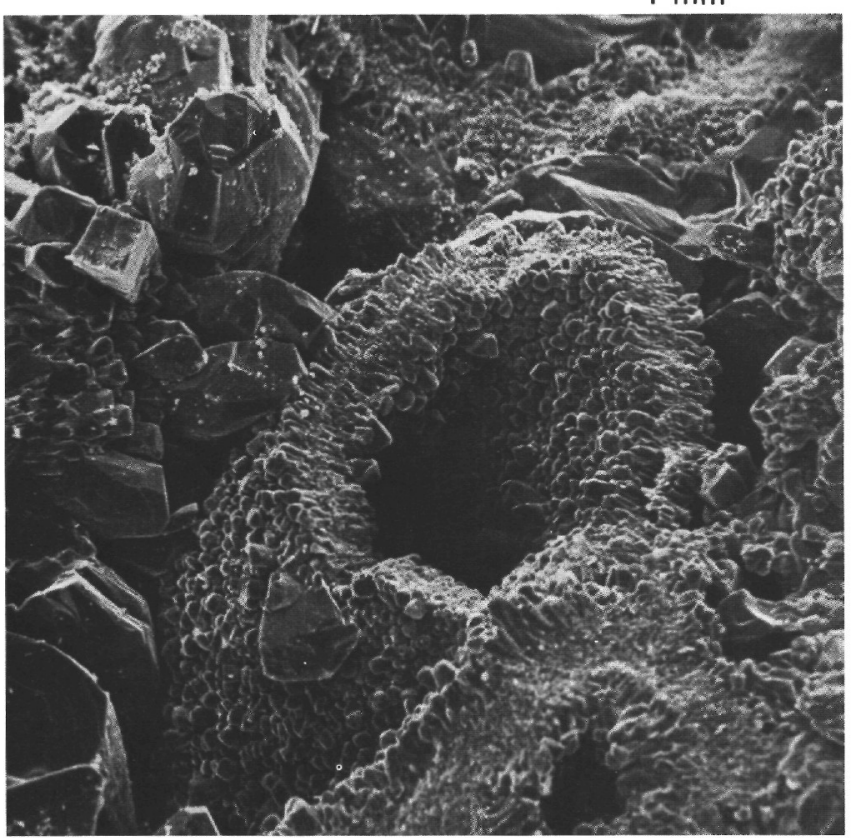

5

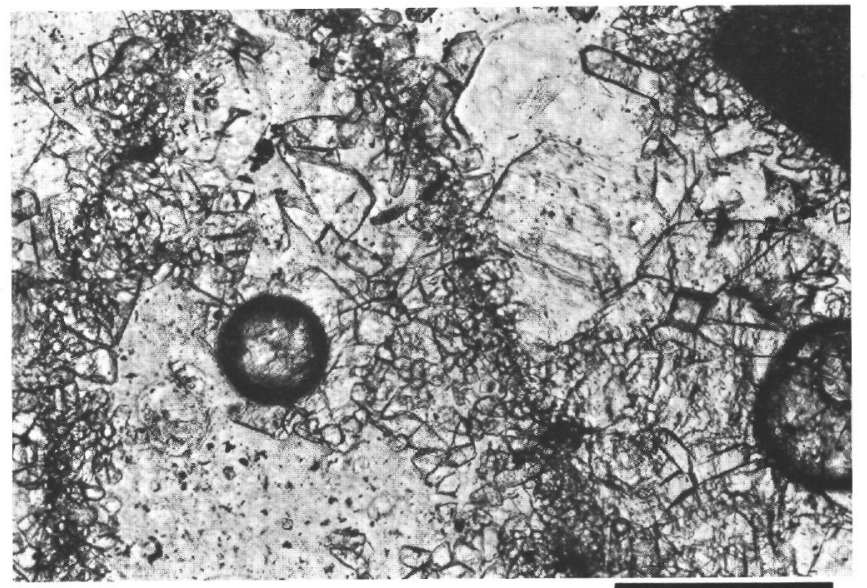

$0.2 \mathrm{~mm}$

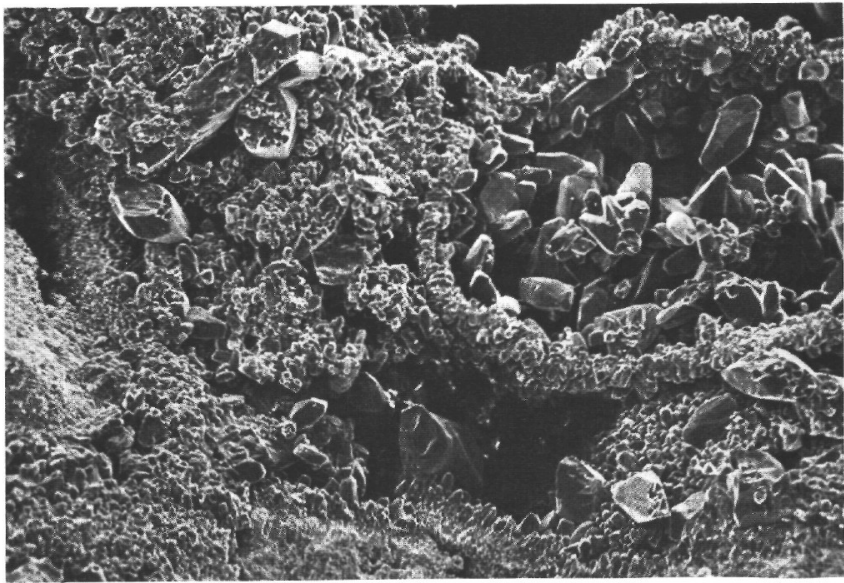

4

$100 \mu \mathrm{m}$

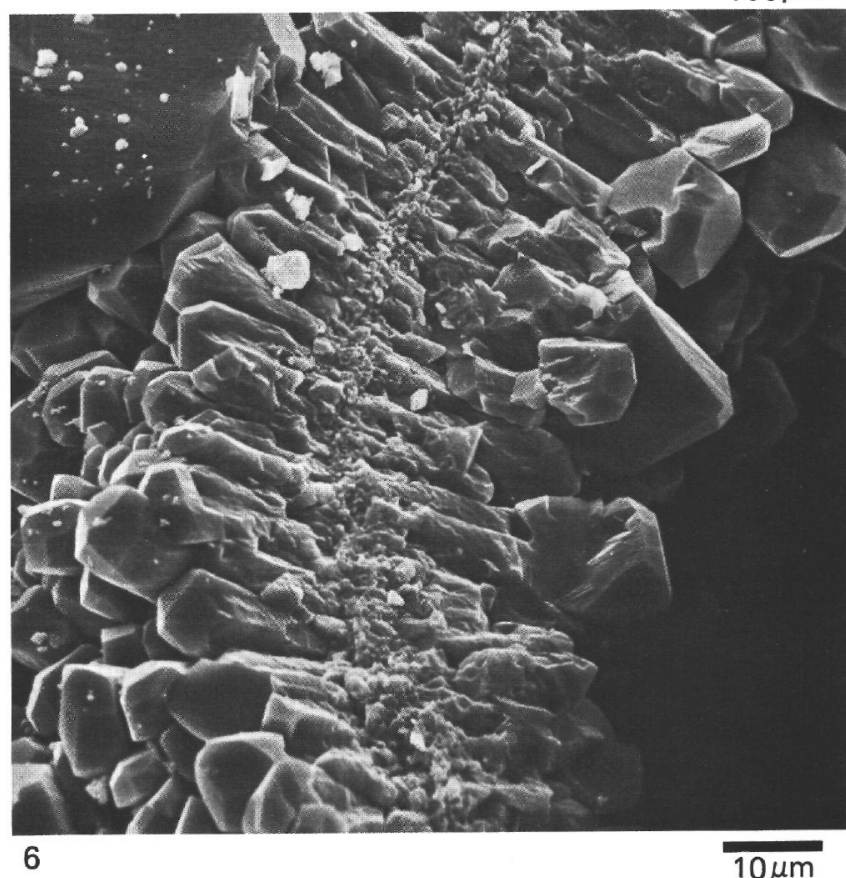


PLATE 3

Dissolution of Aragonitic Particles

Figures 1-3 Partially dissolved molluscan fragment. Before partial dissolution, the molluscan fragment was coated by a micrite rim which still outlines the original shape of the skeletal fragment. Formation of the micrite rim was followed by partial dissolution of skeletal aragonite and cementation of the mold and interparticle porosity by first fibrous palisade rim and later blocky calcite cement. The undissolved part of the skeleton fragment shows its original structure, and is probably still aragonite. Middle to upper Paleocene, Suiko Seamount, Sample 433B-4-1, $30 \mathrm{~cm}$. Thin section: figure 1, plane light; figures 2 and 3 , nicols crossed.

Figures 4, 7 Fragments of codiacean algae. Before dissolution of the aragonitic thallus, the utricles have been filled by micrite (high-magnesium calcite?) and the skeletal fragment enveloped by a micrite rim. The secondary intraparticle void space is partially filled by fibrous calcite cement and a few larger blocky calcite crystals. Fibrous calcite crystals and large blocky calcite partially cement the interparticle pore space. Middle to upper Paleocene, Suiko Seamount. Figure 4: Sample 433B-4-1, 28-32 cm. Thin section: plane light. Figure 7: Sample 433B$4-1,25-28 \mathrm{~cm}$. Thin section: plane light.

Figures 5, 6 Codiacean algal fragment. The skeletal structure is partially replaced by brown-stained neomorphic micrite, partially dissolved and cemented by calcite. Utricles are filled with micrite. Middle to upper Paleocene, Suiko Seamount, Sample 433B-4-1, 25-28 cm. Thin section: figure 5, plane light; figure 6 , nicols crossed.

Figure 8 Dasyclad algal fragment. The pores are filled by micrite, and the thallus is surrounded by a micrite rim. After dissolution, the skeletal mold has been filled by calcite cement. Upper Paleocene to middle Eocene, Ōjin Seamount, Sample 430A-4-1, 7 $\mathrm{cm}$. Thin section: plane light. 
PLATE 3
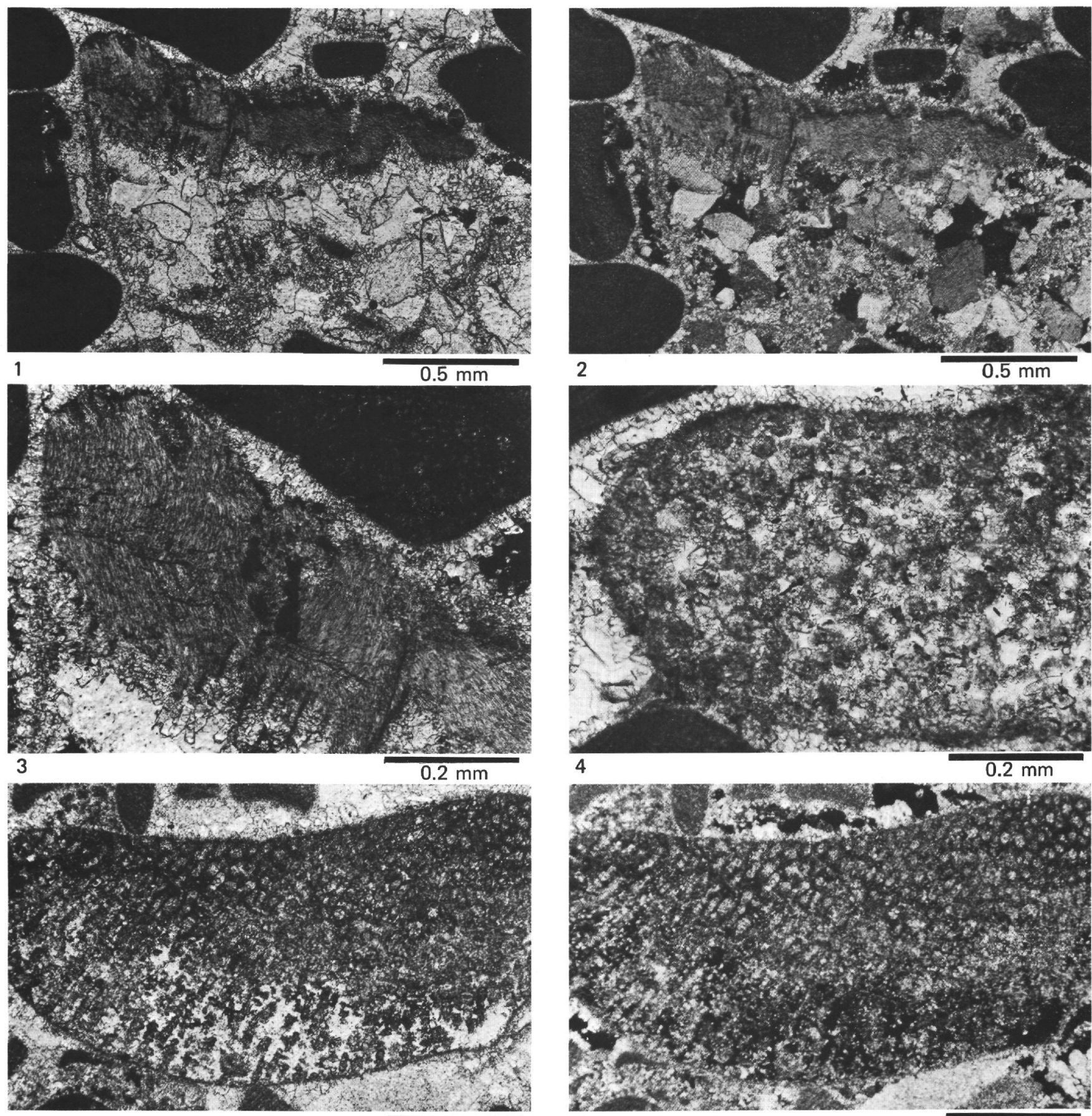

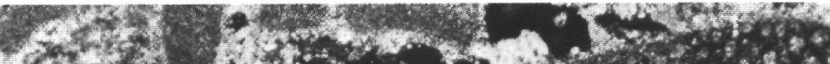

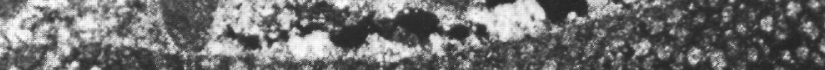

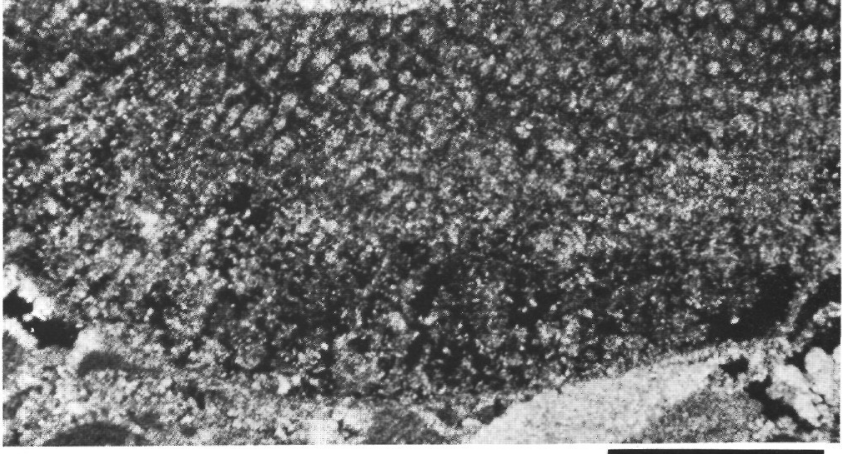

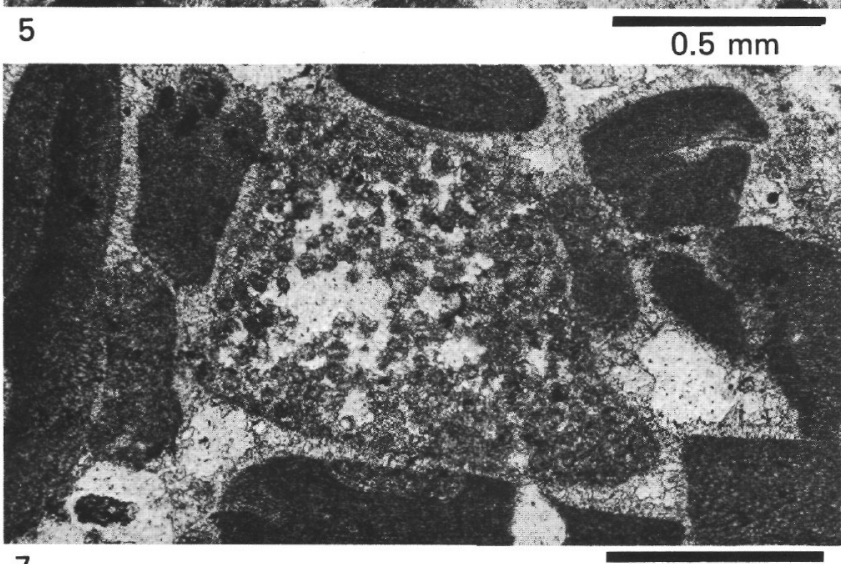

7

$0.5 \mathrm{~mm}$ 6

$0.5 \mathrm{~mm}$

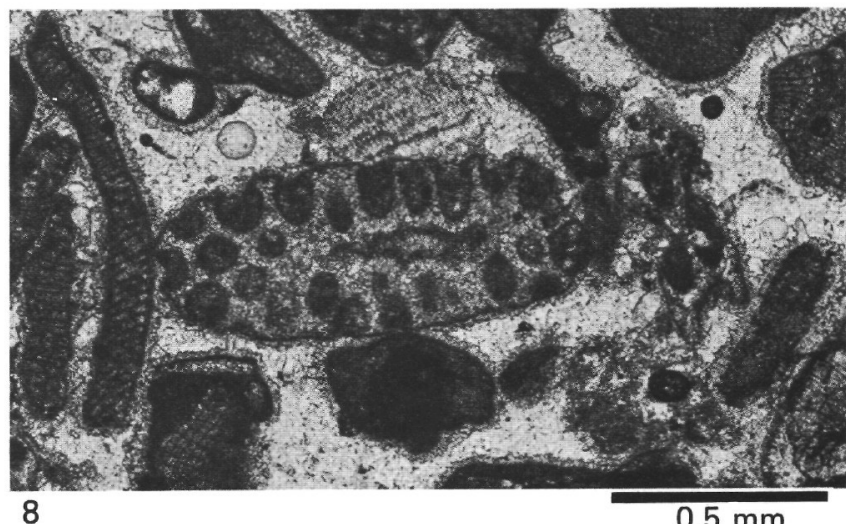




\section{PLATE 4}

Cementation in Shallow-Water Carbonates, Lower Tertiary, Suiko and Nintoku Seamounts

Figures 1, 2 Friable calcarenite. Many grains are loosely cemented by micrite and microspar into composite lumps. Bryozoans show intraskeletal sparry calcite cements. Middle to upper Paleocene, Suiko Seamount, Sample 433B-3-1, 20-60 cm. Thin section: figure 1 , plane light; figure 2 , nicols crossed.

Figure 3, 4 Shallow-water calcarenite cemented by calcitic fibrous palisade rim and later "dog-tooth" calcite. These two generations are particularly clearly visible inside the ostracode shell in the center of the photomicrographs. Note also the syntaxial overgrowth of early palisade rim on pre-existing radial fabric in the ostracode shell and the syntaxial overgrowth on the echinoderm fragment in the upper left. Middle to upper Paleocene, Suiko Seamount, Sample 433B-4-1, 25-28 cm. Thin section: figure 3 , plane light; figure 4 , nicols crossed.

Figures 5-8 Shallow-water calcarenite, mainly coralline algae and calcite-filled molds of former aragonitic particles, cemented by early palisade rim and later blocky calcite developing from "dog-tooth" calcite. Figures 5 and 6: Middle to upper Paleocene, Suiko Seamount, Sample 433B-4-1, 36-37 cm. Figures 7 and 8: upper Paleocene to middle Eocene, Nintoku Seamount, Sample 432-A-1-1, 46 $\mathrm{cm}$. Thin sections: figures 5 and 7 , plane light; figures 6 and 8 , nicols crossed. 
Plate 4
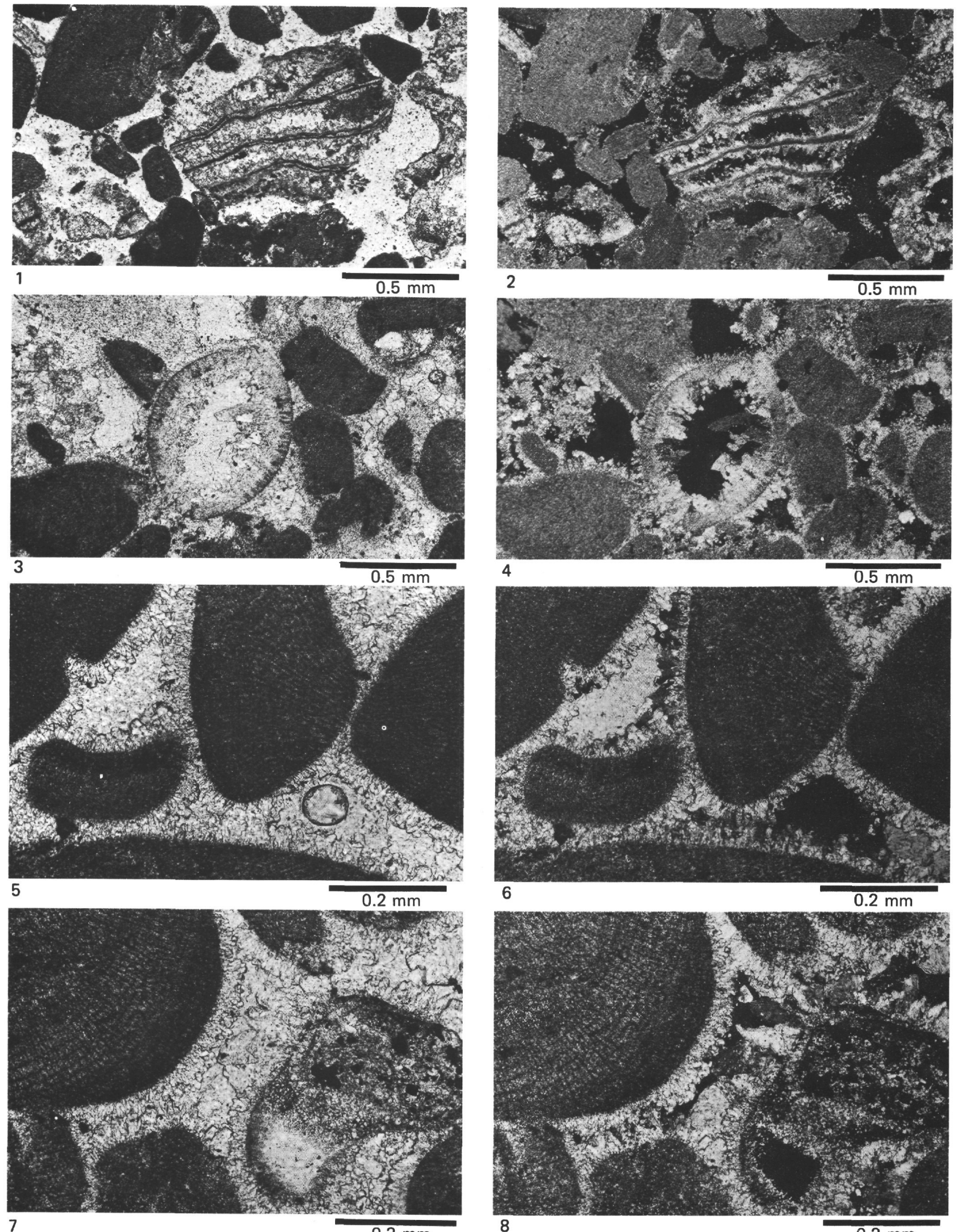
PLATE 5

Stereoscan Electron Micrographs of Calcitic Cements in Shallow-Water Limestones, Middle to Upper Paleocene, Suiko Seamount, Site 433

Figures 1, 2 Shallow-water particles, mainly coralline algae, are coated and cemented by a first generation of fibrous calcite growing perpendicular to substrate. Later cement consists of large "dog-tooth" calcite crystals oriented tangentially or obliquely to the first generation of palisade calcite. Sample 433B-4-1, $25 \mathrm{~cm}$.

Figures 3-6. Fibrous calcite crystals of early palisade rim cement in essentially parallel orientation perpendicular to substrate. The crystals have steep, curved scalenohedral faces on their sides; they often terminate with two sets of rhombohedral faces rotated against each other by $60^{\circ}$. Figures 3-5: Sample 433B-4-1, $28 \mathrm{~cm}$. Figure 6: Sample 433B-4-1, $17 \mathrm{~cm}$. 


\section{PLATE 5}
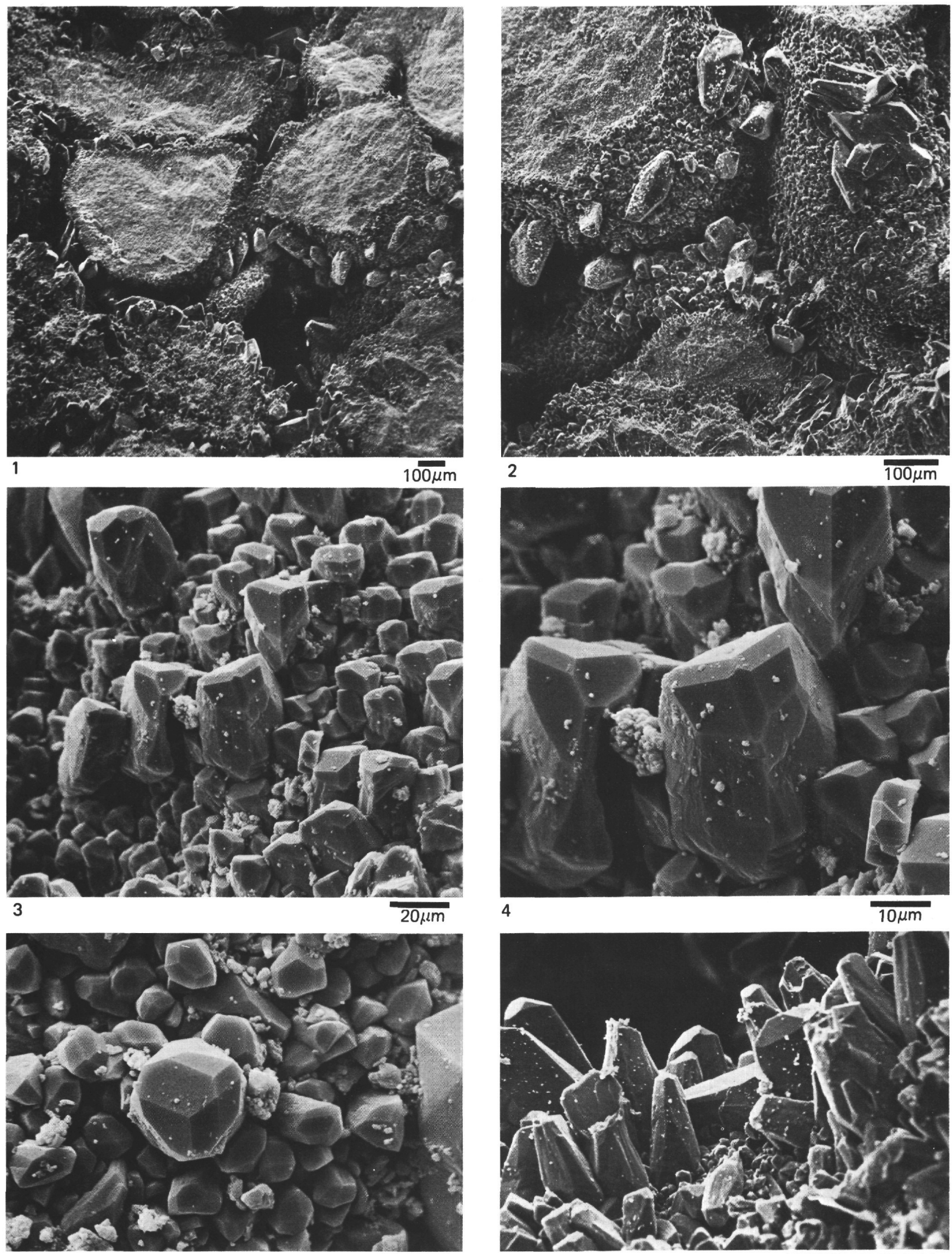

5

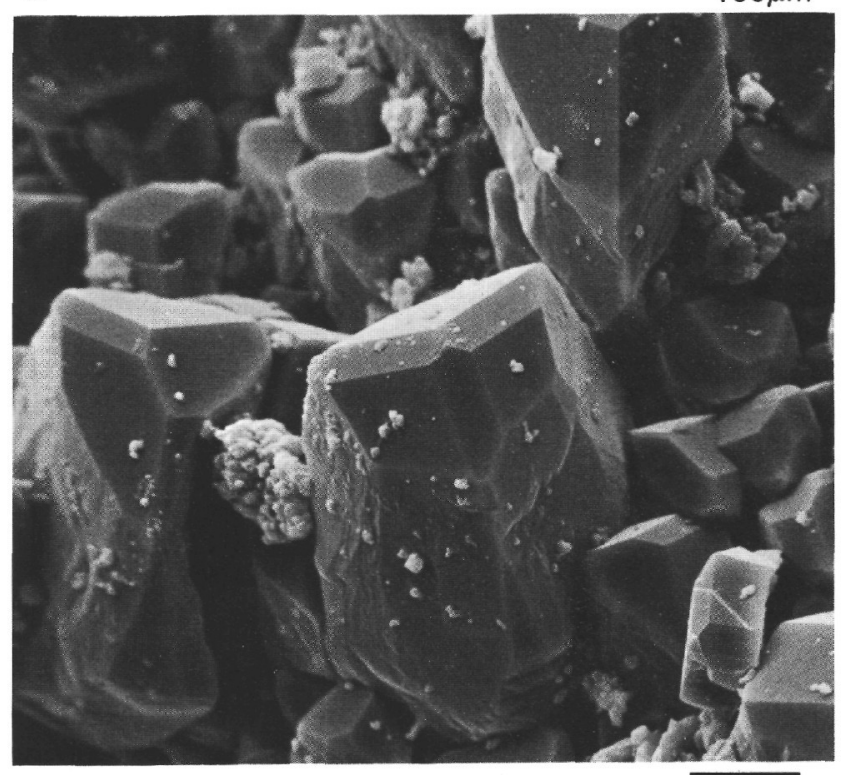

4

$10 \mu \mathrm{m}$

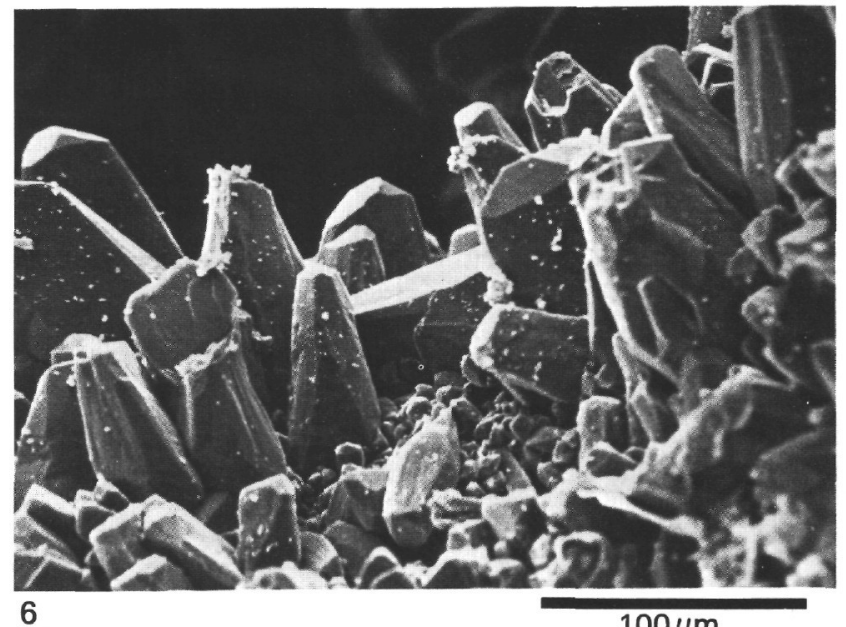

6

$100 \mu \mathrm{m}$ 


\section{PLATE 6}

Stereoscan Electron Micrographs of Calcitic Cements in ShallowWater Limestones, Middle to Upper Paleocene, Suiko Seamount, Site 433, and Upper Paleocene-Lower Eocene, Nintoku Seamount, Site 432

Figures 1-3 Shallow-water particles, mainly coralline algae, are coated and cemented together by a first generation of fibrous calcite. Later cement consists of large "dog-tooth" calcite crystals and euhedral phillipsite. The "dog-tooth" calcite crystals are characterized by steep, curved scalenohedral and flat rhombic crystal faces. They grow tangentially or obliquely from the substrate of earlier palisade rim cement. Middle to upper Paleocene, Suiko Seamount, Sample 433B-4-1, $17 \mathrm{~cm}$.

Figures 4, 5 Within Core 433B-4-1, there is a systematic increase in cementation in the shallow-water limestones toward the contact with the underlying basalt. Figure 4 shows clearly discontinuous growth of early palisade rim cement and later blocky calcite cement developing from the "dog-tooth" crystals. Figure 5 shows complete cementation of coralline algal sand by palisade rim cement and blocky calcite. Middle to upper Paleocene, Suiko Seamount. Figure 4: Sample 433B-4-a, $30 \mathrm{~cm}$. Figure 5: Sample 433B-4-1, $33 \mathrm{~cm}$.

Figure 6 Volcanic fragments (left and upper right), cemented by an early rim cement of smectite and a later cement of calcite showing steep scalenohedral faces and terminating distally with two sets of rhombohedra. Upper Paleocene-lower Eocene, Nintoku Seamount, Sample 432A-2-1, $35 \mathrm{~cm}$. Scale bar: $50 \mu \mathrm{m}$. 
PLATE 6
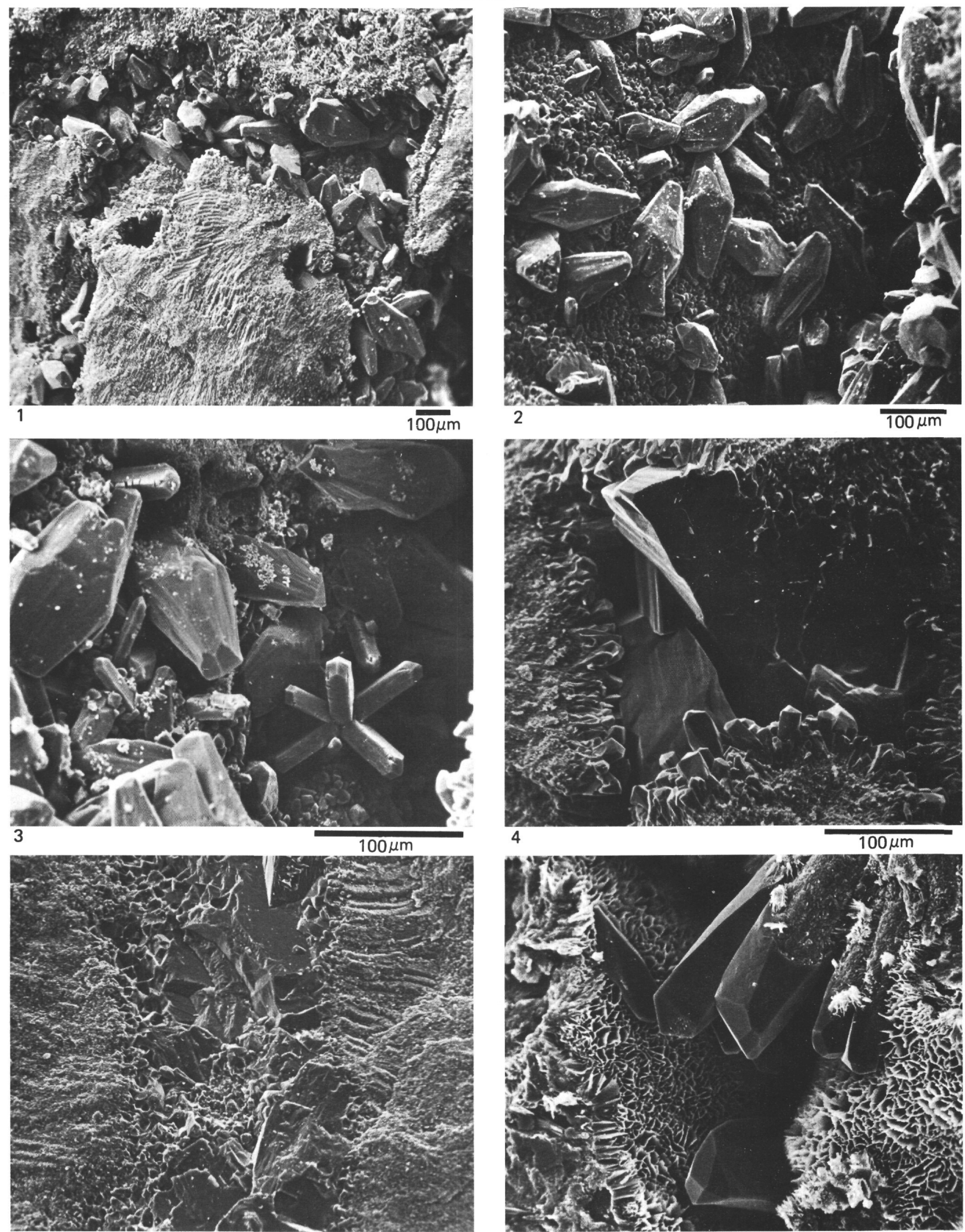

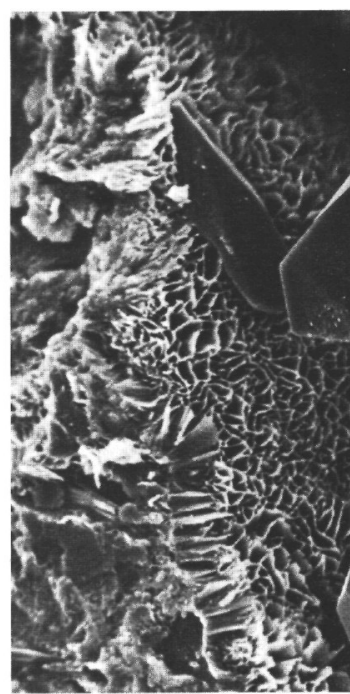

6
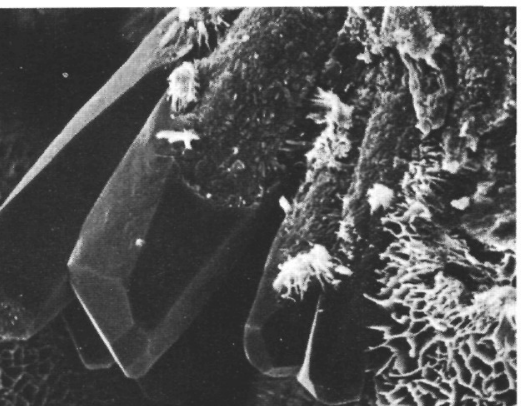
1. $40 \mathrm{cos}$

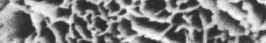
Fath $12 x+15$

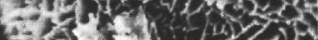
$3 \times 2 x+2=5$

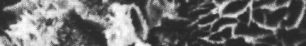
Niving $\frac{2}{2}$

$50 \mu \mathrm{m}$ 


\section{PLATE 7}

Phillipsite Cement in Shallow-Water Limestones, Lower Tertiary, Ōjin and Suiko Seamounts, Sites 430 and 433

Figures 1-3 Shallow-water particles (coralline algae, echinoderms, etc.) cemented by a first generation of calcitic palisade rim cement which is syntaxial on radial biogenic fabric (upper right), by syntaxial overgrowth on echinoderm fragments, and a second generation of blocky calcite and phillipsite. Note that large euhedral phillipsite crystal grows from nucleation site on early calcite cement without a volcanic precursor. Middle to upper Paleocene, Suiko Seamount, Sample 433B-4-1, 25-28 $\mathrm{cm}$. Thin section: figures 1 and 2, plane light; figure 3 , nicols crossed.

Figures 4-7 Shallow-water carbonate material, mainly coralline algae and micrite rims, cemented by (1) calcitic fibrous palisade rim cement and (2) blocky calcite and euhedral phillipsite. Note that euhedral phillipsite crystals grow from foundations of early calcitic cements and as void-filling cements into pore-space. Cruciform twin of phillipsite is shown in figure 7. Figures 4 and 5: Middle to upper Paleocene, Suiko Seamount, Sample 433B-4-1, 28-33 $\mathrm{cm}$. Figure 6: Upper Paleocene to middle Eocene, Ōjin Seamount, Sample 430A-4-1, $7 \mathrm{~cm}$. Figure 7: Middle to upper Paleocene, Suiko Seamount, Sample 433B-4-1, 25-28 cm. Thin sections: plane light.

Figures 8, 9 Syntaxial overgrowth on echinoderm fragment. These syntaxial overgrowths envelop, as large poikilotopic crystals, euhedral crystals of phillipsite (black in figure 9) which grew contemporaneously with, but at a slower rate than, the cements, and into the pore space. Middle to upper Paleocene, Suiko Seamount, Sample 433C-1-1, $24 \mathrm{~cm}$. Thin section: figure 8 , plane light; figure 9 , nicols crossed. 
PLATE 7
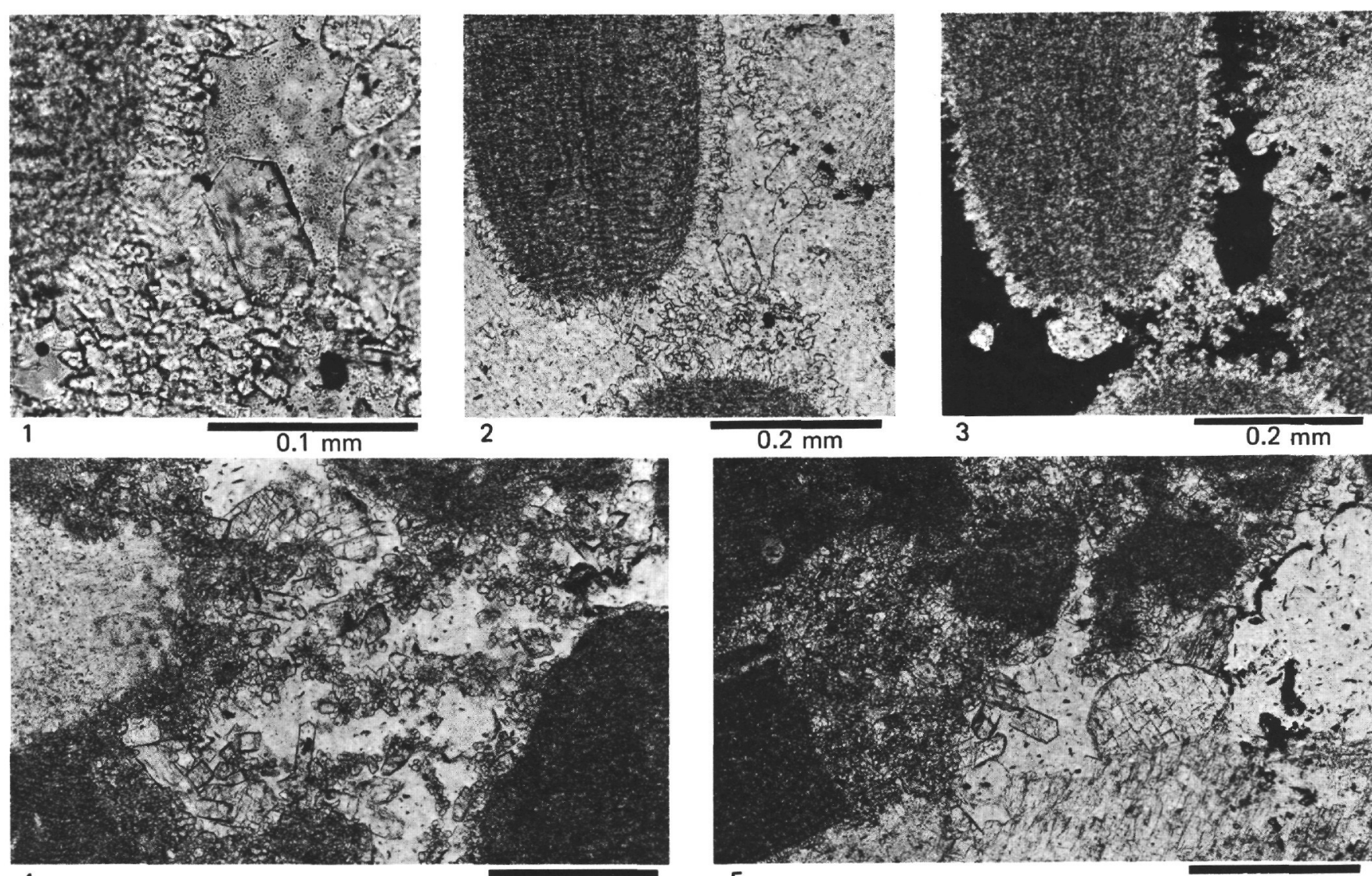

4

$0.2 \mathrm{~mm}$

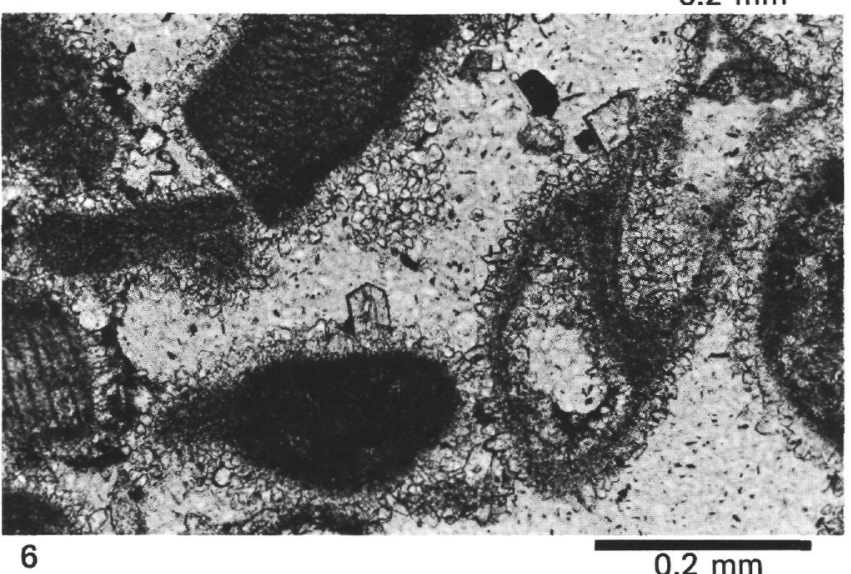

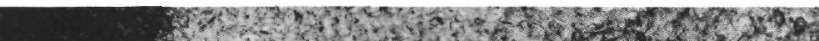

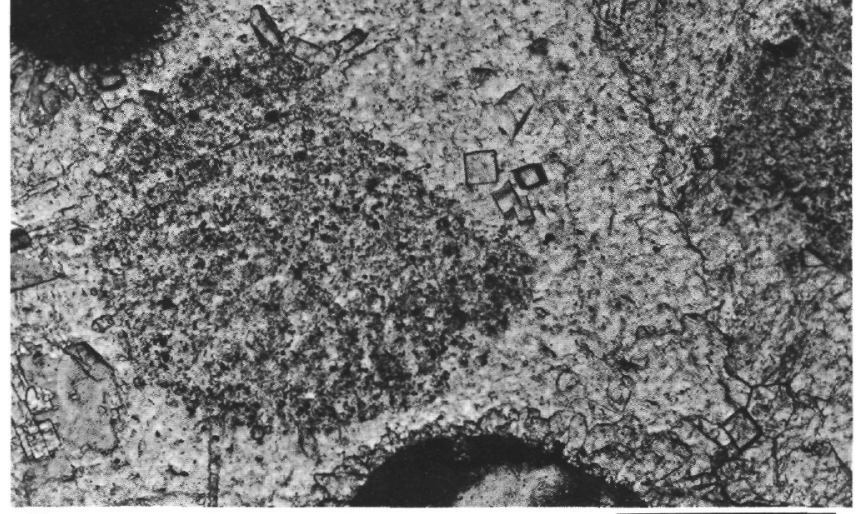

8

$0.2 \mathrm{~mm}$

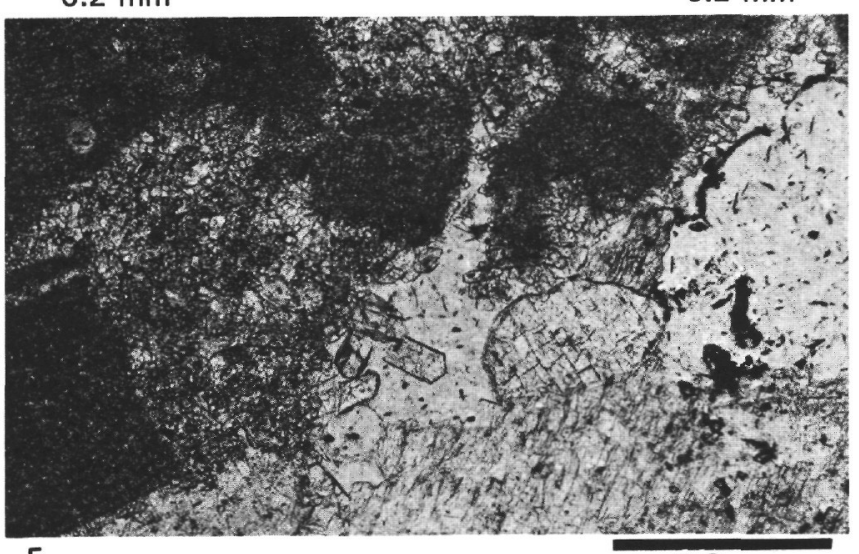

5

$0.2 \mathrm{~mm}$
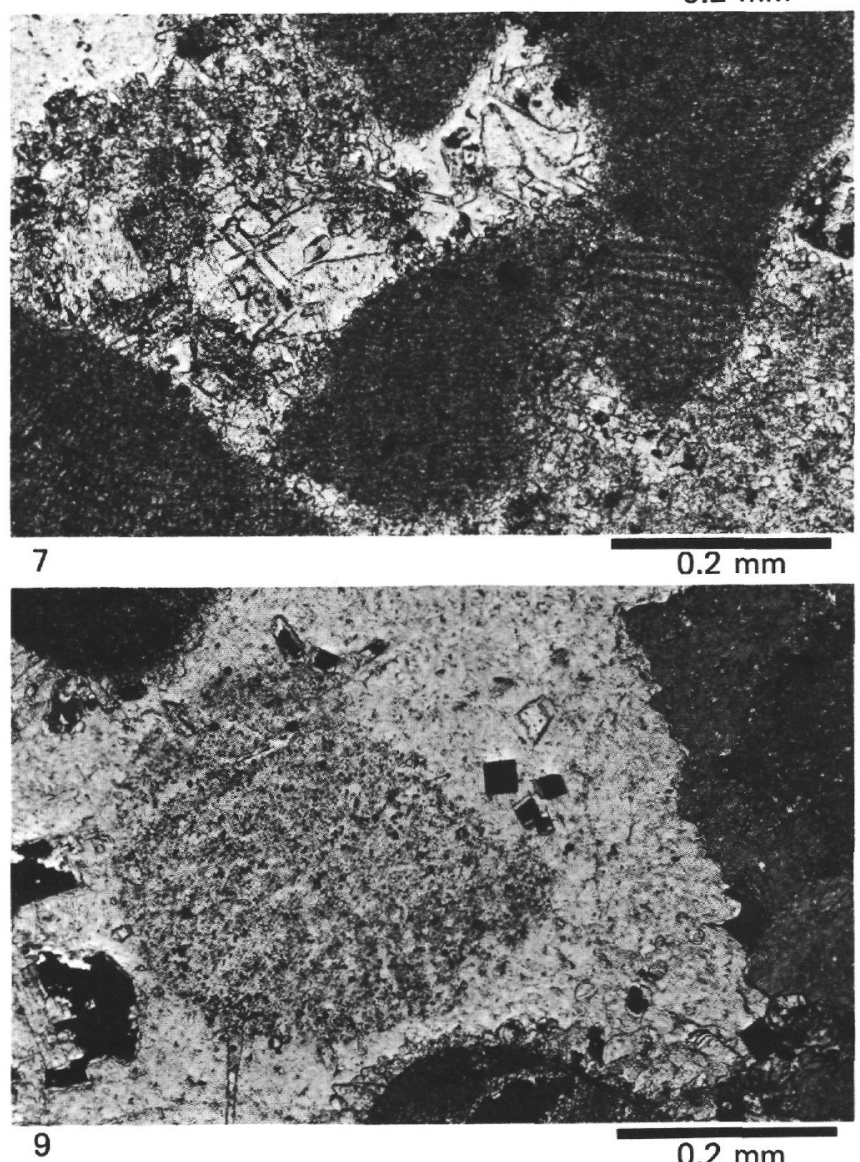


\section{PLATE 8}

Phillipsite Cement in Shallow-Water Limestones, Lower Tertiary, Kōkō and Suiko Seamounts, Sites 308 and 433

Figures 1, 2 Large, formerly aragonitic fossil replaced by neomorphic calcite and filled by calcitic and zeolitic cement. Fine-grained, stained neomorphic spar replaced the earlier skeletal structure, whereas former intraskeletal voids are partially cemented by fibrous palisade rim, blocky calcite, and phillipsite. Middle to upper Paleocene, Suiko Seamount, Sample $433 \mathrm{C}-4-1,24 \mathrm{~cm}$. Thin section: figure 1, plane light; figure 2 , nicols crossed.

Figures 3-6 Enlargements from figures 1 and 2: calcite and phillipsite cements growing from foundations of micrite rims and neomorphic microspar replacing former aragonitic skeleton. Note that euhedral phillipsite grew from nucleation sites on calcite and that there is no volcanic precursor within this otherwise pure carbonate fabric. Middle to upper Paleocene, Suiko Seamount, Sample 433C-4-1, $24 \mathrm{~cm}$. Thin section: figures 3 and 5, plane light; figures 4 and 6 , nicols crossed.

Figure $7 \quad$ Euhedral phillipsite crystal growing in patches of microspar derived from neomorphism and early cementation. Middle to upper Paleocene, Suiko Seamount, Sample 433B-4-1, $25 \mathrm{~cm}$. Stereoscan electron micrograph.

Figure $8 \quad$ Cruciform twin of phillipsite, smear slide of insoluble residue. Middle to upper Paleocene, Suiko Seamount, Sample 433B-4-1, $21 \mathrm{~cm}$.

Figure 9 Plate of Halimeda, replaced by neomorphic calcite and filled with calcite and zeolite (? phillipsite, black arrows) cement (cf. Matter and Gardner, 1975 , Plate 1, figure 2). Contemporaneous growth of clear sparry calcite and zeolite shows that sparry calcite is true cement precipitated from pore solution. Lower Eocene, Kōkō Seamount, Sample $308-4-1,58 \mathrm{~cm}$. Thin section: plane light. Thin section courtesy of A. Matter. 
PLATE 8
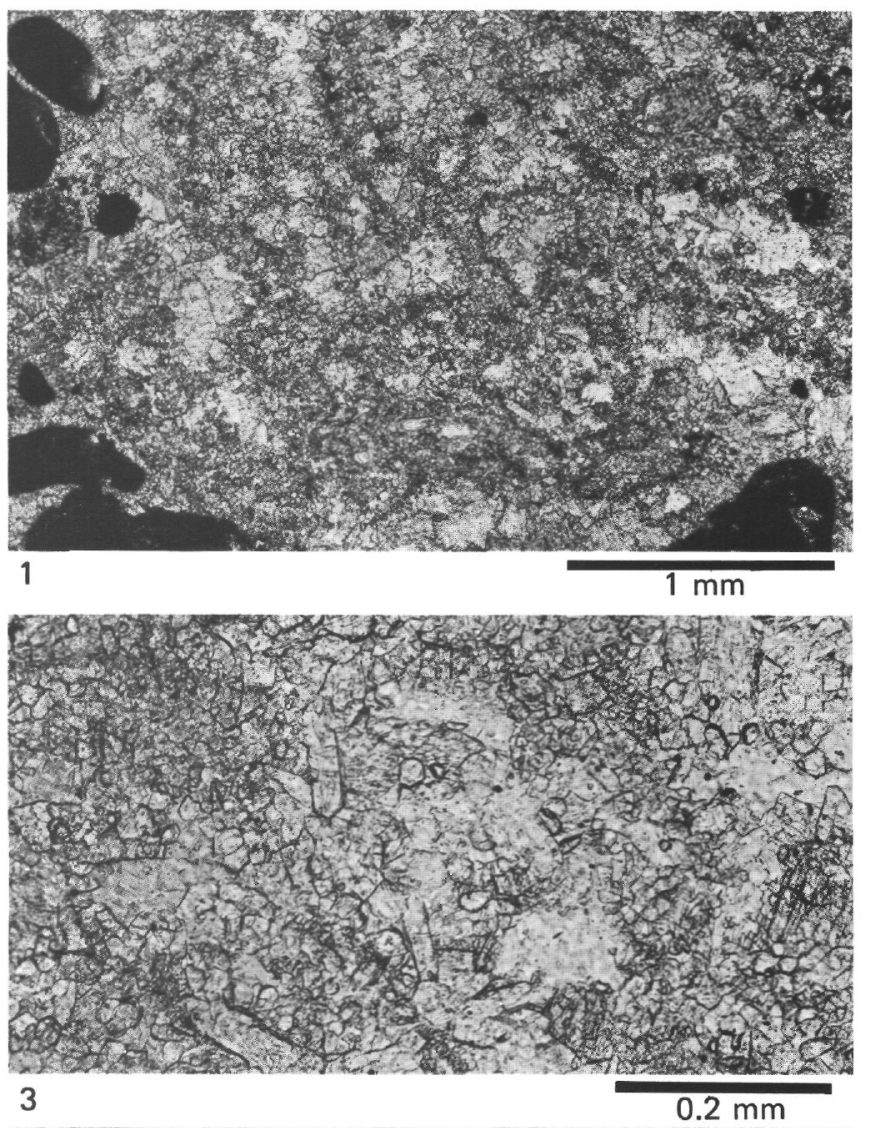
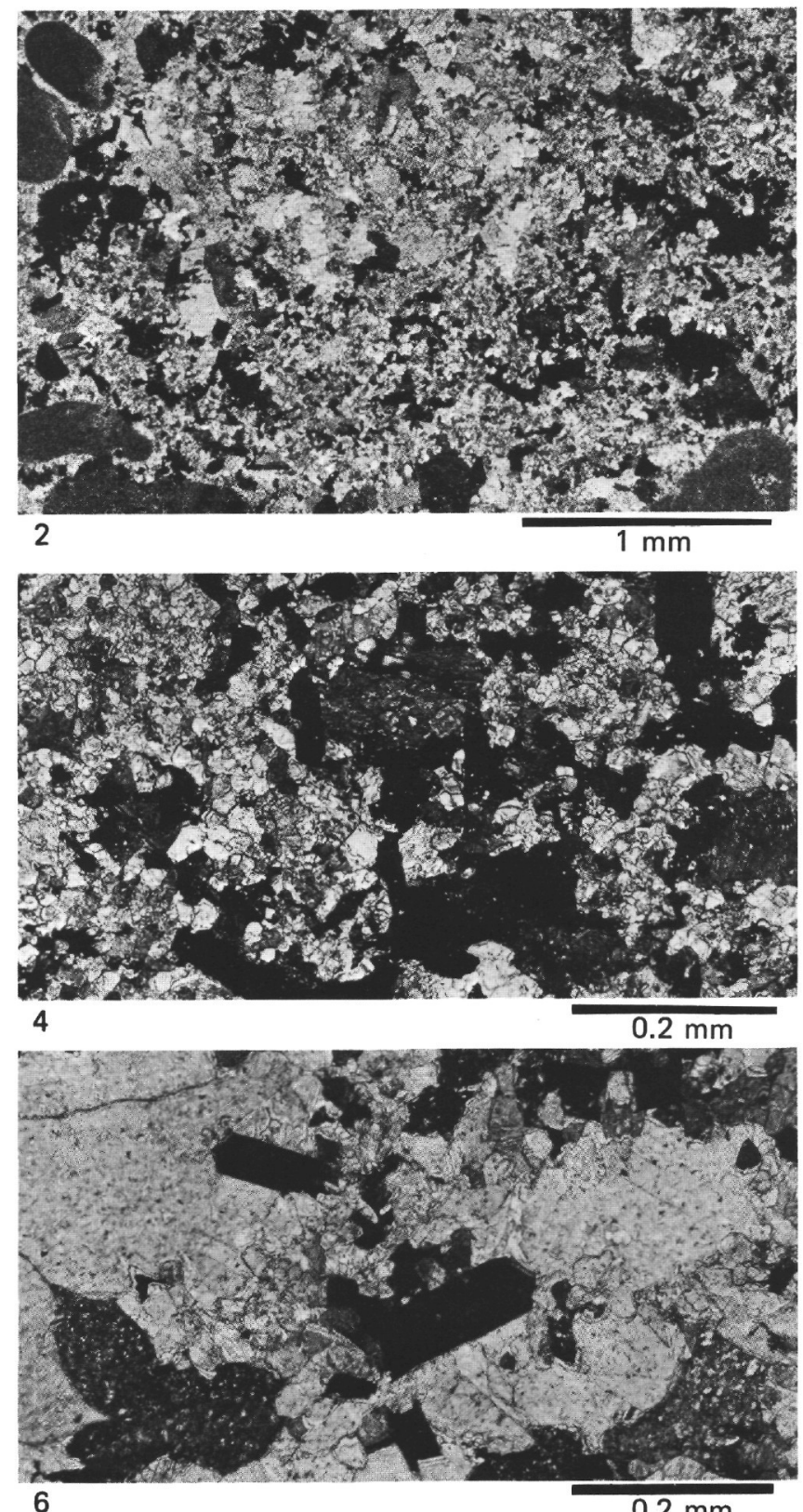

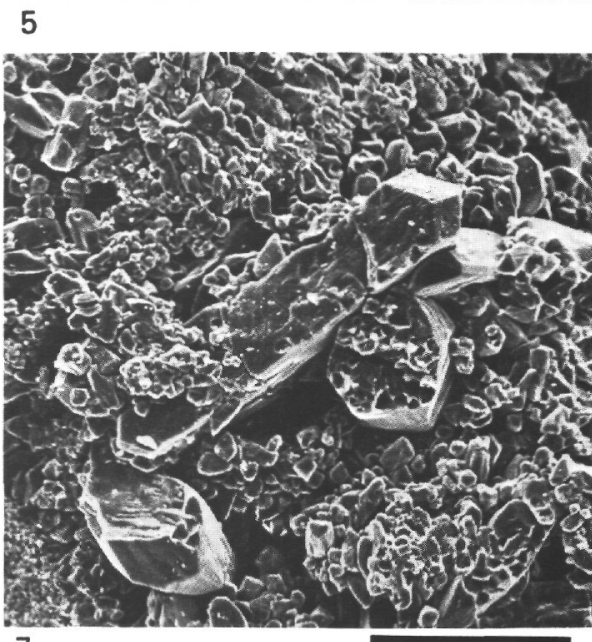

7

$100 \mu \mathrm{m}$
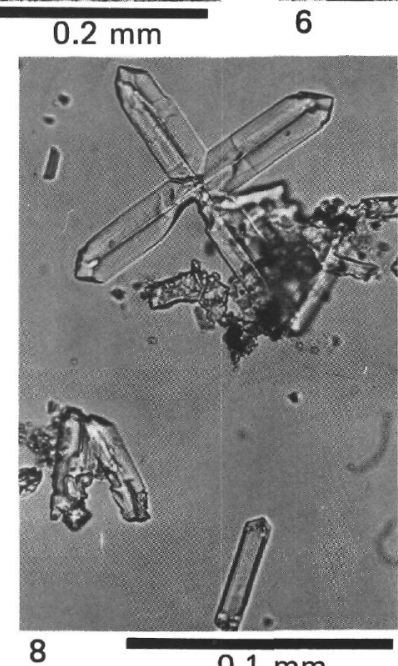

$0.1 \mathrm{~mm}$ 


\section{PLATE 9}

Stereoscan Electron Micrographs of Phillipsite Cements in Shallow-Water Limestones, Middle to Upper Paleocene, Suiko Seamount, Site 433

Figures 1, 2 Calcarenite composed of shallow water material, mainly coralline algae, and cemented by a first generation of fibrous calcite and a second generation of large "dog-tooth" calcite and phillipsite. Sample 433-4-1, $21 \mathrm{~cm}$.

Figure 3 Phillipsite cement in calcarenite. The euhedral phillipsite crystals show pseudo-orthorhombic symmetry and two-sided "domal" terminations. They grow from nucleation sites on early diagenetic calcite cements. Sample 433B-4-1, $28 \mathrm{~cm}$.

Figure $4 \quad$ Euhedral phillipsite crystal, partly enveloped by "dog-tooth" calcite crystal of the second generation of calcitic cement. Sample 433B-4-1, $17 \mathrm{~cm}$.

Figure 5 Multisector twin of phillipsite. Sample 433B-4-1, $17 \mathrm{~cm}$.

Figure 6 Cruciform twin of phillipsite crystal, partly enveloped by large calcite crystals. Sample 433C-1-1, 13 $\mathrm{cm}$. 


\section{PLATE 9}

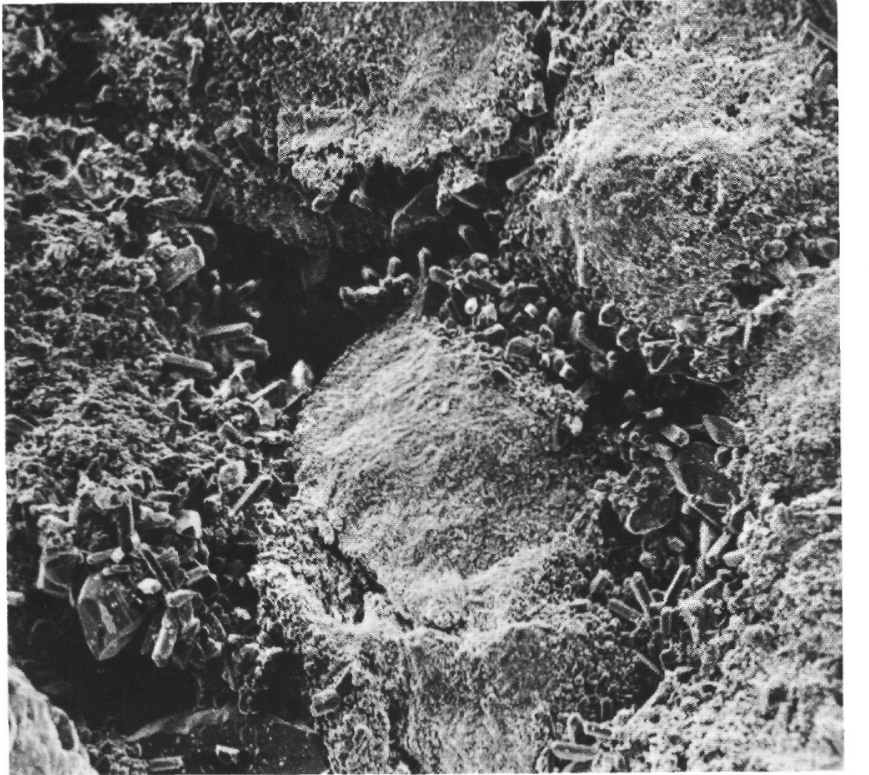

1

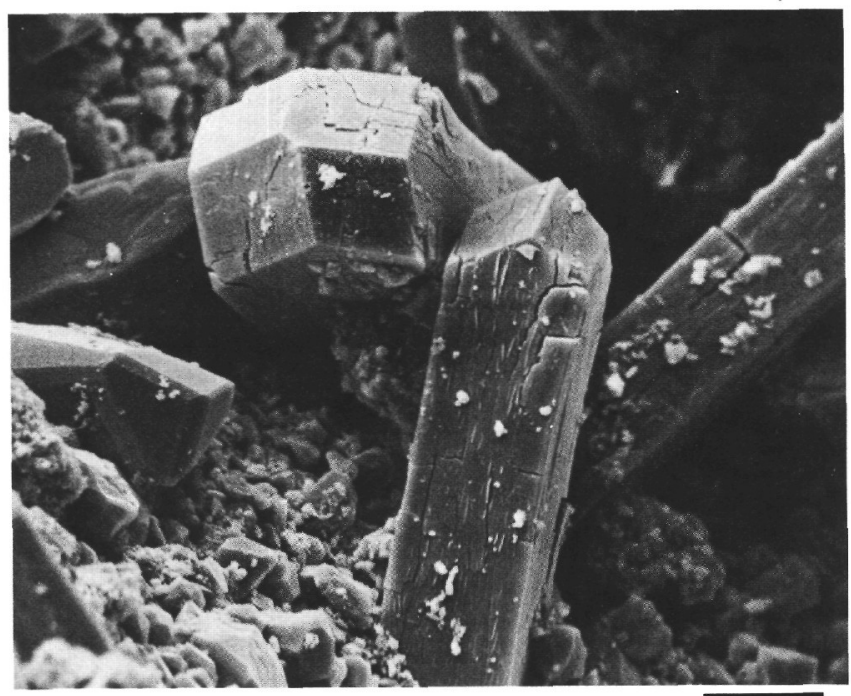

3

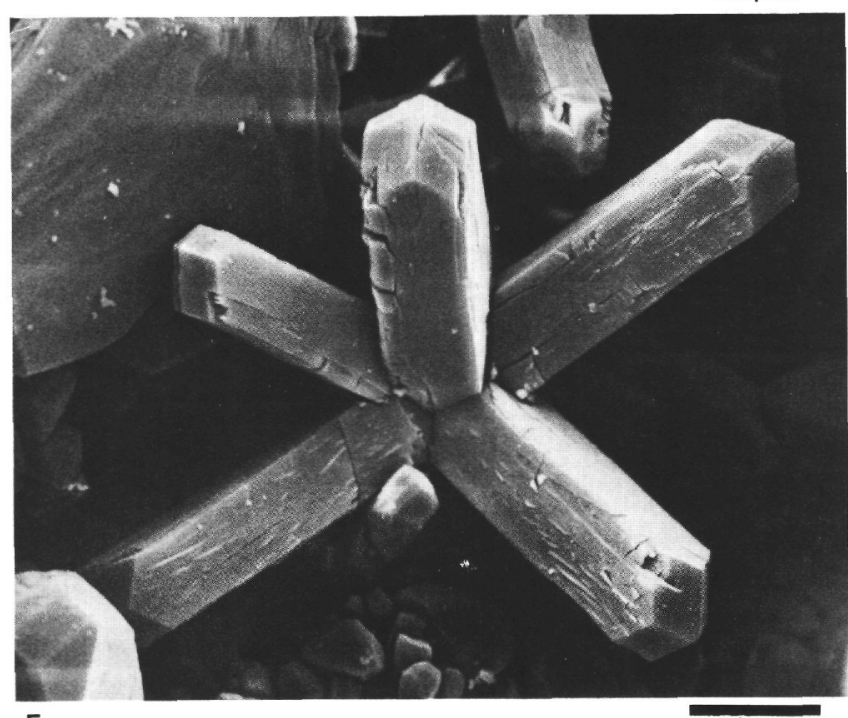

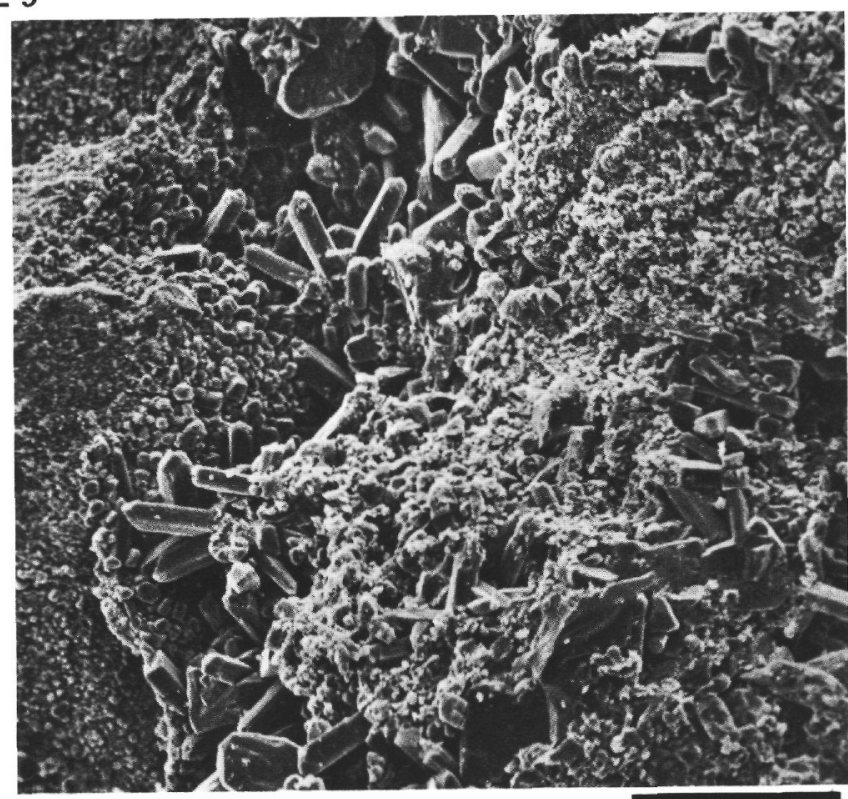

2

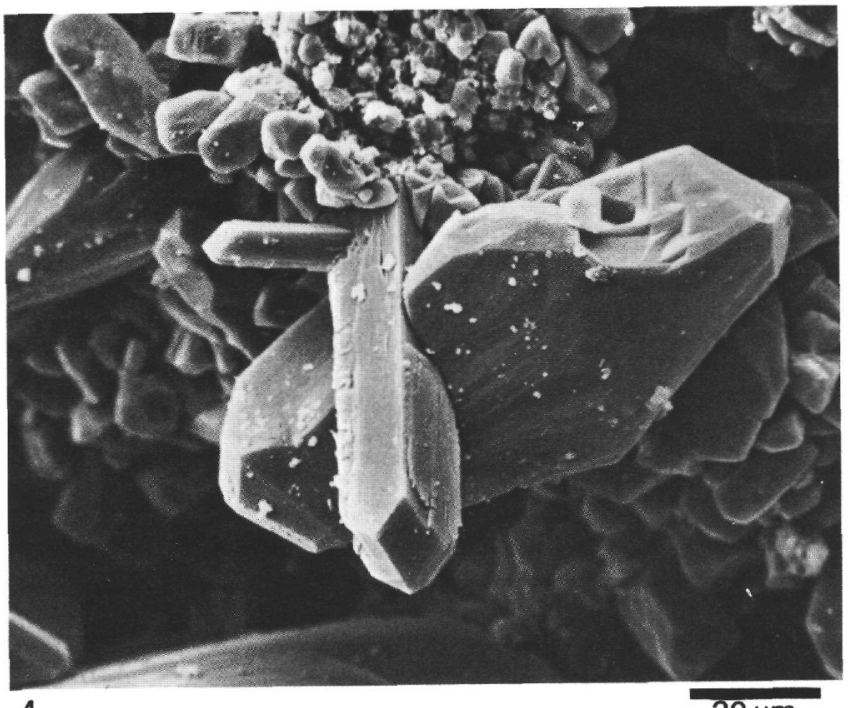

4

$20 \mu \mathrm{m}$

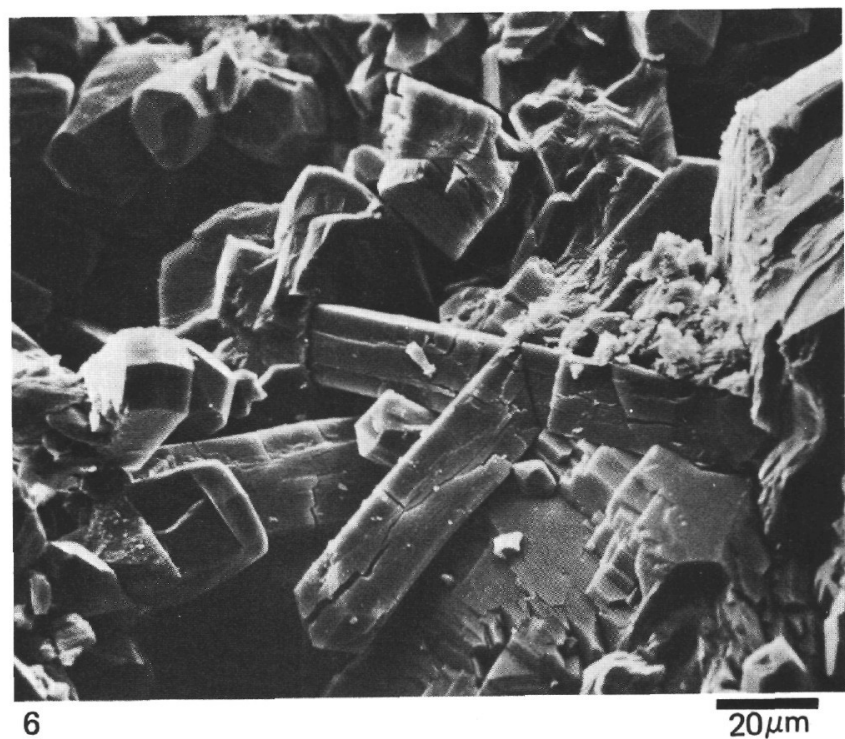


PLATE 10

Stereoscan Electron Micrographs of Zeolite Cements in Shallow-Water Limestones, Ōjin and Nintoku Seamounts

Figure $1 \quad$ Phillipsite, calcite, and clinoptilolite(?) cementing interparticle pore space in shallow-water calcarenite. Upper Paleocene to middle Eocene, Nintoku Seamount, Sample 432A-1-4, $46 \mathrm{~cm}$.

Figures 2-4 Shallow-water calcarenite cemented by calcite and euhedral, pseudotetragonal, elongate, prismatic crystals of clinoptilolite with domal terminations. Upper Paleocene to middle Eocene, Ōjin Seamount, Sample 430A-4-1, $7 \mathrm{~cm}$.

Figures 5, 6 Euhedral twinned crystals of clinoptilolite associated with an unidentified rod-shaped mineral of unknown composition. Upper Paleocene to middle Eocene, Ōjin Seamount, Sample 430A-4-1, $7 \mathrm{~cm}$. 
PLATE 10

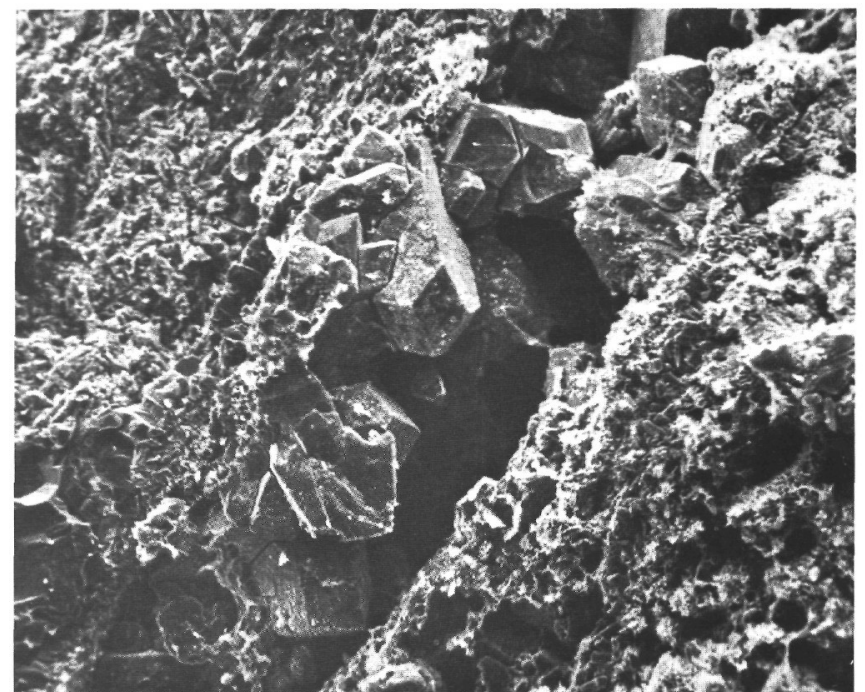
$1100 \mu \mathrm{m}$
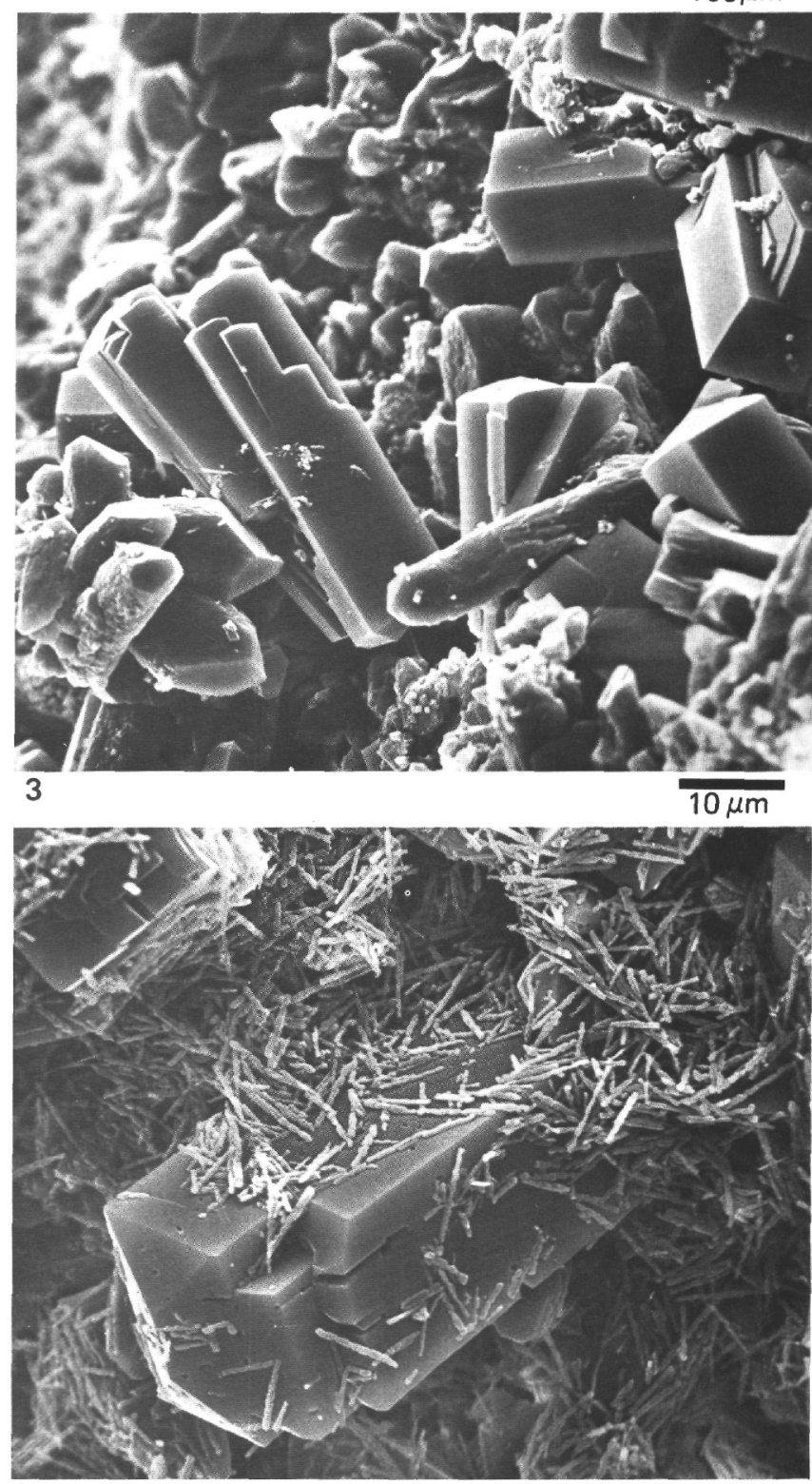
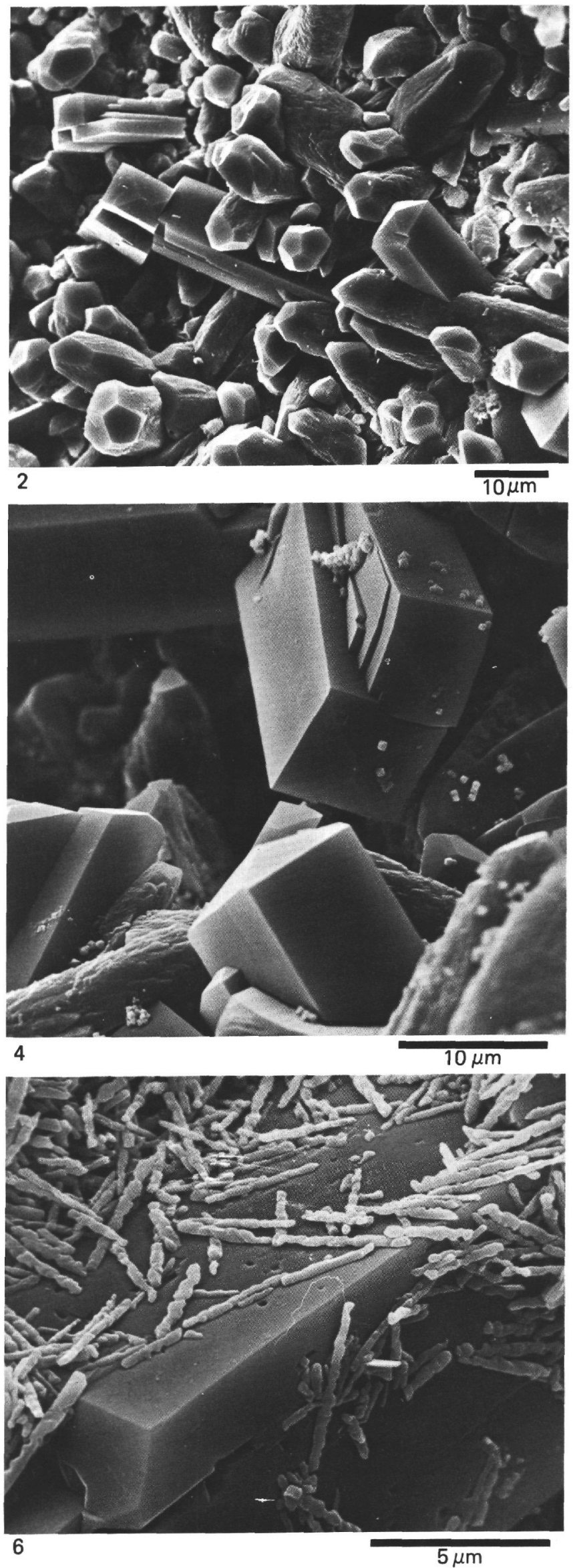